\title{
EFEITO DO MANEJO ALTERNATIVO SOBRE A DESCOMPACTAÇÃO DO SOLO, FUNGOS MICORRÍZICOS ARBUSCULARES NATIVOS E PRODUÇÃO EM POMAR CONVENCIONAL DE TANGOR 'MURCOTT’.
}

SÉRGIO KENJI HOMMA

Dissertação apresentada à Escola Superior de Agricultura "Luiz de Queiroz”, Universidade de São Paulo, para obtenção do Título de Mestre em Ecologia de Agroecossistemas.

P I R A C I C A B A

Estado de São Paulo - Brasil Março de 2005 


\title{
EFEITO DO MANEJO ALTERNATIVO SOBRE A DESCOMPACTAÇÃO DO SOLO, FUNGOS MICORRÍZICOS ARBUSCULARES NATIVOS E PRODUÇÃO EM POMAR CONVENCIONAL DE TANGOR 'MURCOTT'.
}

\section{SÉRGIO KENJI HOMMA}

Engenheiro Agrônomo

\author{
Orientador: Prof. Dr. HASIME TOKESHI
}

\begin{abstract}
Dissertação apresentada à Escola Superior de Agricultura “Luiz de Queiroz”, Universidade de São Paulo, para obtenção do Título de Mestre em Ecologia de Agroecossistemas.
\end{abstract}

P I R A C I C A B A

Estado de São Paulo - Brasil

Março de 2005 
Dados I nt ernaci onai s de Cat al ogação na Publi cação ( $C l P$ ) DI VI SÃO DE BI BLI OTECA E DOCUMENTAÇÃO - ESALQI USP

Homma, Sérgio Kenji

Efeito do manejo alternativo sobre a descompactação do solo, fungos micorrizícos arbusculares nativos e produção em pomar convencional de tangor 'Murgott' / Sérgio Kenji Homma. - - Piracicaba, 2005.

84 p. : il.

Dissertação (mestrado) - - Escola Superior de Agricultura Luiz de Queiroz, 2005. Bibliografia.

1. Cobertura vegetal 2. Descompactação do solo 3. Fungo micorrízico 4. Manejo do solo 5. Nutrição vegetal 6 . Tangerina I. Título

CDD 634.31

"Permi tida a cópia total ou parcial deste documento, desde que citada a fonte - O aut or" 


\section{A Deus e ao Mestre Mokiti Okada}

pela luz, pela permissão e pela proteção

\section{Agradeço}

\section{À Mariângela \\ minha eterna companheira, pelo amor, \\ estímulo, paciência e compreensão durante \\ mais essa jornada}

Dedico

À Agricultura Brasileira

Ofereço 


\section{AGRADECIMENTOS}

Ao Prof. Dr. Hasime Tokeshi pela orientação deste trabalho e por muitos outros na minha vida profissional.

À Profa. Dra. Siu Mui Tsai pelas valiosas orientações e pelo apoio em diversas etapas deste trabalho, em especial nas análises e orientações sobre as micorrizas.

Ao Prof. Dr. Paulo Roberto de Camargo e Castro pelas importantíssimas contribuições para a cientificidade deste trabalho.

Ao Dr. Fernando Augusto de Sousa, Gerente Geral da Korin, grande incentivador da Agricultura Natural e deste mestrado, pelo apoio e pelas valiosas orientações no âmbito pessoal e profissional.

À Korin Agropecuária Ltda pelo amplo apoio estrutural e de pessoal.

À Secretaria do curso de Ecologia de Agroecossistemas, em especial a Regina Celis Telles de Oliveira, pela presteza e carinho durante todo o curso.

Ao grande companheiro e amigo Eng. Agr. Eduardo S. Prochnou que se envolveu com total afinco na condução do experimento.

À Bióloga Ms. Giuliana Guimarães, que esteve presente em tão boa hora, pela contribuição fundamental no início deste trabalho. 
Ao Técnico de Laboratório Francisco C. Montrazi (Chiquinho do CENA) pela ajuda irrestrita e fundamental nas análises das micorrizas.

À Dra. Milene Moreira-Souza pelas valiosas dicas em relação às análises de micorrizas.

Aos funcionários da Korin Alencar Saito, Valdionei Giassi e Wellington R. Porto pela ajuda nas coletas e análises e Cecília I. Mendes pelas revisões dessa dissertação.

À Sakae Kinjo e Hiroshi Ota, coordenadores do Centro de Pesquisa Mokiti Okada, pelo apoio irrestrito através da estrutura laboratorial e pessoal.

Aos amigos e funcionários do Centro de Pesquisa Mokiti Okada Luíz Augusto Mendes, Márcio Ramos, Josbel Borges, Geralda Ferreira Barcelos, Keiko Takahashi e Dr. Paulo Chagas pelo apoio e cooperação nos trabalhos laboratoriais.

Aos estagiários Paulo Croisfelt, Luiz Felipe Cavallari, Luiz Rôncoli, Angela Feltrin e Fábio Pires pela importantíssima ajuda em diferentes momentos do trabalho.

À Profa. Marisa de Cássia Picollo e ao Prof. Lorival Fante Jr. pelas avaliações das imagens digitalizadas de raízes no SIARCS.

Ao Sr. Eduardo Lucato, proprietário da Fazenda Santo Antônio, por ceder a área experimental e pelas importantes informações para esse trabalho.

Aos Srs. Benedito e André, funcionários da Fazenda Santo Antônio, pela presteza com que colaboraram para a execução e condução do experimento.

A todas as pessoas que de alguma forma contribuíram para a realização desse trabalho. 
“A profundidade da inteligência depende da força da sinceridade.”

\section{Mokiti Okada}

"Há duas maneiras de se viver a vida. Uma, como se nada fosse milagre. A outra, como se tudo fosse milagre."

Albert Einstein 


\section{SUMÁRIO}

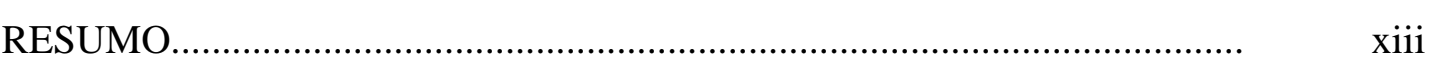

SUMMARY ........................................................... $\quad \mathrm{xV}$

1 INTRODUÇÃO........................................................... 1

2 REVISÃO DE LITERATURA...................................................................

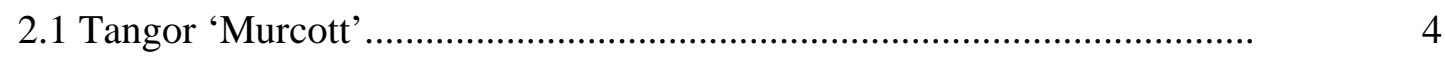

2.2 Manejo Alternativo em citros................................................................... 5

2.3 Compostos fermentados Bokashi........................................................ 9

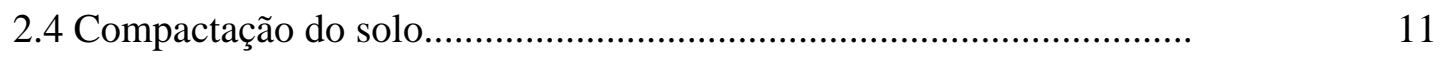

2.5 Densidade radicular superficial................................................................ 13

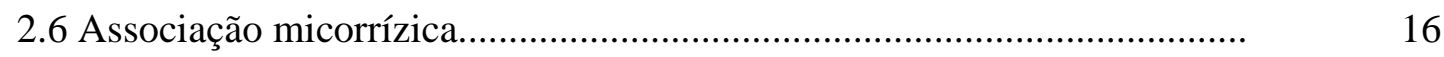

2.6.1 Fungos micorrízicos........................................................................ 16

2.6.2 Associação micorrízica arbuscular em citros.......................................... 18

2.6.3 O manejo agrícola e os FMAs nativos ................................................. 19

3 MATERIAL E MÉTODOS...................................................................... 23

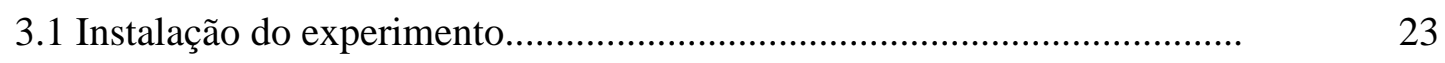

3.1.1 Caracterização do local..................................................................... 23

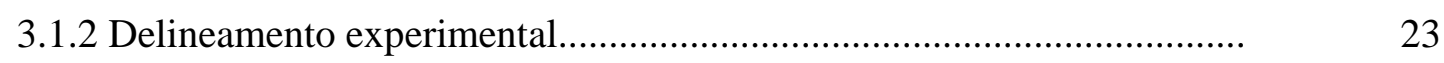

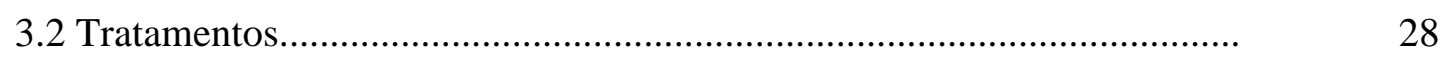

3.2.1 Tratamento Convencional.................................................................... 28

3.2.2 Tratamento Alternativo..................................................................... 28

3.3 Compactação do solo e sistema radicular............................................ 30

3.3.1 Resistência do solo à penetração.......................................................... 30

3.3.2 Densidade radicular superficial.............................................................. 31 
3.4 Associação micorrízica..........................................................................

3.4.1 Colonização micorrízica radicular..................................................... 32

3.4.2 Quantidade de esporos no solo............................................................ 33

3.5 Conteúdo de nutrientes foliares............................................................. 34

3.6 Produção e qualidade de frutos................................................................ 34

3.6.1 Produção de frutos............................................................................ 34

3.6.2 Teores de sólidos solúveis ( ${ }^{\circ}$ brix) e acidez total.................................. 34

3.7 Outras avaliações............................................................................. 35

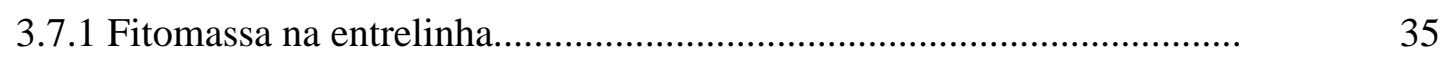

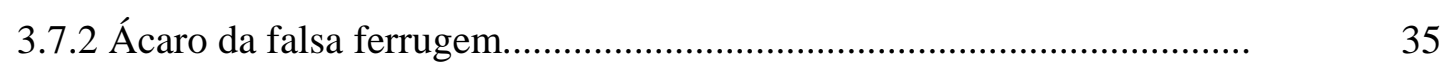

3.7.3 Ortézia...................................................................................... $\quad 35$

3.8 Estatística........................................................................................

4 RESULTADOS E DISCUSSÃO..............................................................

4.1 Compactação do solo e sistema radicular............................................ 37

4.1.1 Resistência do solo à penetração............................................................. 37

4.1.2 Densidade radicular superficial............................................................ 42

4.2 Associação micorrízica...........................................................................

4.2.1 Colonização micorrízica radicular........................................................ 45

4.2.2 Quantidade de esporos no solo............................................................. 46

4.3 Conteúdo de nutrientes foliares.............................................................. 48

4.4 Produção e qualidade de frutos...............................................................

4.4.1 Produção de frutos..............................................................................

4.4.2 Teores de sólidos solúveis ( ${ }^{\circ}$ brix) e acidez total................................... 55

4.5 Outras avaliações.............................................................................. 56

4.5.1 Fitomassa da entrelinha................................................................. 56

4.5.2 Ácaro da falsa ferrugem.................................................................. 59

4.5.3 Ortézia............................................................................................... 59

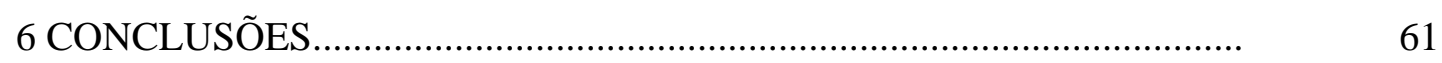

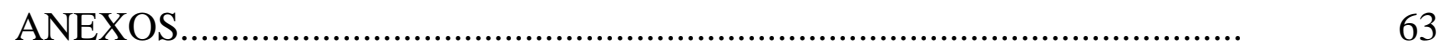

REFERÊNCIAS BIBLIOGRÁFICAS......................................................... 69 


\section{LISTA DE FIGURAS}

1 Precipitação e médias das temperaturas máximas e mínimas

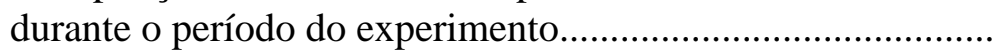

Página

2 Croqui da área experimental e apresentação esquemática do delineamento e das parcelas de avaliação.....

3 Esquema dos pontos de aferição da resistência do solo à penetração na parcela de avaliação.

4 Resistência do solo à penetração em $\left(\mathrm{Kgf.cm}^{-2}\right)$ em 3 pontos da faixa da linha de plantio ( $\mathrm{L}_{1}, \mathrm{~L}_{2}$ e $\mathrm{L}_{3}=0$, 70 e $140 \mathrm{~cm}$ a partir do eixo da linha em direção a entrelinha) em dois tratamentos, Convencional e Alternativo, em pomar de tangor 'Murcott' no período de 2002 a 2004.

5 Resistência do solo à penetração $\left(\mathrm{Kgf}_{\mathrm{Cm}}{ }^{-2}\right)$ em 3 pontos da faixa de entrelinha ( $E_{1}, E_{2}$ e $E_{3}=210,280$ e $350 \mathrm{~cm}$ a partir do eixo da linha em direção a entrelinha) em dois tratamentos, Convencional e Alternativo, em pomar de tangor 'Murcott' no período de 2002 a 2004.

6 Imagens de raízes de tangor Murcott de dois tratamentos, Convencional e Alternativo, após remoção do solo superficial com jatos de água e tingimento com tinta branca.

7 Colonização de FMAs nativos em raízes finas e esporos viáveis encontrados em $50 \mathrm{~g}$ de solo em pomar de tangor 'Murcott' em dois tratamentos, Convencional e Alternativo, coletadas em duas diferentes épocas do ano no período de 2002 a 2004

8 Flutuação populacional de ácaro da falsa ferrugem (Phyllocoptruta oleivora) em plantas de tangor 'Murcott' em dois tratamentos, Convencional e Alternativo, no período de janeiro de 2002 a setembro de 2004 . 


\section{LISTA DE TABELAS}

Página

1 Análise de fertilidade de solo dos tratamentos, Convencional e Alternativo, em Tangor Murcott, amostradas nos meses de agosto nos anos de 2002 a 2004

2 Teores de umidade do solo (\%) em 3 profundidades, nos dois tratamentos, Convencional e Alternativo, na faixa de plantio (linha) e na faixa de trânsito (entrelinha) no período de 2002 a 2004, coletadas concomitantemente à avaliação de resistência do solo à penetração........

3 Massa fresca de raízes de tangor 'Murcott' em dois tratamentos, Convencional e Alternativo, coletadas em duas diferentes épocas do ano no período de 2002 a 2004

4 Massa seca de raízes de tangor 'Murcott' em dois tratamentos, Convencional e Alternativo, coletadas em duas diferentes épocas do ano 2004.

5 Resultados em área $\left(\mathrm{cm}^{2}\right)$ e comprimento $(\mathrm{cm})$ de raízes superficiais obtidas pelo processamento de imagens digitalizadas no software SIARCS de três plantas de tangor 'Murcott', provenientes de dois tratamentos, Convencional e Alternativo, referente à área de $3 \mathrm{~m}^{2}$ sob a copa, 2 m a partir do tronco na direção da linha e 1,5 m em direção a entrelinha 
6 Colonização de FMAs nativos em raízes finas de tangor 'Murcott' em dois tratamentos, Convencional e Alternativo, coletadas em duas diferentes épocas do ano no período de 2002 a 2004

7 Quantidade de esporos viáveis de FMAs nativos encontrados em 50 g de solo coletado sob a copa de plantas de tangor 'Murcott' em dois tratamentos, Convencional e Alternativo, em duas diferentes épocas nos anos de 2003 e 2004.

8 Análise química foliar de tangor 'Murcott' em dois tratamentos, Convencional e Alternativo, coletadas em duas diferentes épocas do ano no período de 2002 a 2004

9 Produção, quantidade e peso médio de frutos de tangor 'Murcott' em dois tratamentos, Convencional e Alternativo, no período de 2002 a 2004

10 Avaliação da produção, quantidade e peso médio de frutos de 3 plantas de cada tratamento, Convencional e Alternativo, fora das parcelas de avaliação, com porte e aparência semelhante, escolhidas dentro da área experimental, comparada com as médias das parcelas experimentais......

11 Sólidos solúveis totais, acidez total (ácido cítrico) e 'ratio’ médio de frutos de tangor 'Murcott' em dois tratamentos, Convencional e Alternativo, no período de 2002 a 2004

12 Quantidade de massa fresca da vegetação infestante na entrelinha de dois tratamentos, Convencional e Alternativo, em tangor 'Murcott', 
roçada em novembro de 2004 e avaliada em janeiro de 2005.

13 Espécies ocorrentes e respectivas massa fresca, em g.m ${ }^{-2}$, da vegetação infestante na entrelinha de dois tratamentos, Convencional e Alternativo, em tangor 'Murcott' apurada em janeiro de 2005...............

14 Incidência de Orthezia praelonga em plantas de tangor 'Murcott' dos tratamentos Convencional e Alternativo da área experimental no período de julho de 2003 a agosto de 2004, apurada através do MIP (Manejo Integrado de Pragas) aplicado na propriedade. 


\section{EFEITO DO MANEJO ALTERNATIVO SOBRE A DESCOMPACTAÇÃO DO SOLO, FUNGOS MICORRÍZICOS ARBUSCULARES NATIVOS E PRODUÇÃO EM POMAR CONVENCIONAL DE TANGOR 'MURCOTT’.}

Autor: SÉRGIO KENJI HOMMA

Orientador: Prof. Dr. HASIME TOKESHI

\section{RESUMO}

O objetivo deste trabalho foi testar um manejo Alternativo em um pomar convencional de Tangerina Murcote (Citrus reticulata, Blanco X Citrus sinensis, Osbeck) enxertadas sobre limão cravo (Citrus limonia, Osbeck), com utilização de composto fermentado Bokashi, avaliando seu efeito sobre a compactação do solo, colonização radicular de fungos micorrízico arbusculares (FMA) nativos, desempenho nutricional, produção e as características tecnológicas dos frutos. O experimento foi delineado separando-se um hectare dentro de um talhão em produção, com 10 anos de idade, onde foram suspensas as aplicações de fertilizantes e defensivos químicos, inclusive os herbicidas, substituindo-os por fontes de nutrientes de baixa solubilidade, de forma que viessem incentivar as interações biológicas, em especial as associações micorrízicas. Para estimular a cobertura vegetal, foi aplicado o composto fermentado Bokashi sobre a vegetação espontânea da linha e entrelinha, procedendo-se o roço mecânico, cuja área foi denominada 'tratamento Alternativo’. Uma área equivalente e contígua, onde os tratos culturais e fitossanitários convencionais foram mantidos, foi utilizada para fins de comparação, sendo esta denominada 'tratamento Convencional'. Os parâmetros eleitos para comparação foram: resistência do solo à penetração, 
densidade radicular superficial, colonização de fungos micorrízicos arbusculares nativos, assim como a quantidade de esporos viáveis no solo, análise de conteúdo de nutriente foliar e produtividade e qualidade de fruto, sendo avaliadas 10 parcelas de 3 plantas para cada tratamento. O manejo Alternativo, com aplicação de composto fermentado Bokashi sobre a vegetação espontânea na entrelinha, propiciou maior cobertura vegetal, 107,5\% a mais, avaliado em janeiro de 2005, principalmente de gramíneas, a qual reduziu a resistência do solo à penetração ao longo do experimento, denotando melhora no estado de compactação do solo em relação ao tratamento Convencional. Também, houve melhor desenvolvimento do sistema radicular superficial, maior índice de colonização radicular de fungos micorrízicos arbusculares (FMA) nativos nas plantas do tangor 'Murcott', em média 10\% superior, e em conseqüência, maior quantidade de esporos viáveis no solo, sendo em média 23\% superior ao tratamento Convencional. Em termos nutricionais, a quantidade aportada de $\mathrm{K}$ no tratamento Alternativo não foi suficiente para suprir adequadamente as necessidades das plantas, demonstrando que é preciso dar maior atenção a esse nutriente nas propostas alternativas de manejo para citros. O teor de B foliar se apresentou significativamente superior e em níveis crescentes ao longo do experimento, atingindo patamares $280 \%$ maiores do que o tratamento Convencional, com teores de até 161,35 mg. $\mathrm{kg}^{-1}$, resultado altamente desejável para este nutriente em citros. Apesar da redução na produtividade inicialmente, o tratamento Alternativo foi superior em massa de frutos por planta na última avaliação, em agosto de 2004, sendo 58,2 kg. planta $^{-1}$ contra 42,9 kg.planta ${ }^{-1}$ do Convencional, embora o tamanho dos frutos e a acidez total tenham sido prejudicados pela deficiência do K. Isso demonstra que em pomar de idade avançada o manejo alternativo deve ser adotado de forma gradual. Em avaliações complementares foi observado que o manejo Alternativo proporcionou melhor equilíbrio na população de Orthezia praelonga, tendo $0,54 \%$ das plantas atacadas, contra 14,06\% no manejo Convencional. 


\title{
EFFECT OF ALTERNATIVE MANAGEMENT ON SOIL DECOMPACTION, INDIGENOUS ARBUSCULAR MYCORRHIZAL FUNGI, AND YIELD IN CONVENCIONAL ORCHARD OF 'MURCOTT' TANGOR
}

\author{
Author: SÉRGIO KENJI HOMMA
}

Adviser: Prof. Dr. HASIME TOKESHI

SUMMARY

The objective of this study was to test an alternative management in a conventional orchard of 'Murcott' tangor (Citrus reticulata, Blanco X Citrus sinensis, Osbeck) grafted on rangpur lime (Citrus limonia, Osbeck) using fermented compost Bokashi, in order to evaluate its effect on soil decompaction, root colonization of indigenous arbuscular mycorrhizal fungi (AMF), nutritional performance, yield and technological characteristics of fruits. The experiment was set by separating one hectare plot in a ten year old yielding orchard, where chemicals fertilizers and pesticides, including herbicides, were discontinued and replacing them by sources of low solubility nutrients and alternative pest control, with the purpose to encouraging the biological interactions, mainly mycorrhizal associations. To stimulate vegetal covering, a fermented compost Bokashi was applied on the spontaneous vegetation of the row e interrow, mechanical clearing was used, and the area was designated 'alternative treatment'. An equivalent and adjoining area, where conventional cultural and phythosanitary treatments were maintained was used for comparative purposes, and was designated 'conventional treatment'. The parameters chosen for comparison were: soil resistance to penetration, surface root density, colonization of indigenous arbuscular 
mycorrhizal fungi, as well as amount of viable spores in the soil, analysis of foliar nutrient content, and fruit yield and quality. Ten plots of 3 plants per each treatment were evaluated. The alternative management with application of fermented compost Bokashi on the spontaneous vegetation on the interrow provided a $107.5 \%$ increase in vegetal covering, mainly grasses, measured in January 2005, which decreased soil resistance to penetration and resulted in an improvement in soil compaction state as compared with the conventional treatment. Also, there were an improved development of surface root systems, a higher rate of root colonization of indigenous arbuscular mycorrhizal fungi (AMF) in plants of 'Murcott' tangor, averaging 10\% higher and, consequently, a higher amount of viable spores in the soil, an average of $23 \%$ higher than of the conventional treatment. In nutritional terms, the input of $\mathrm{K}$ in the alternative treatment was not enough to supply adequately the needs of the plants, indicating that more attention is required in relation to this nutrient in alternative proposals of citrus management. The foliar content of $\mathrm{B}$ was shown to be significantly higher and at increasing rates along the experiment, reaching levels 280\% higher than those of the conventional treatment, having reached contents of up to $161.35 \mathrm{mg} \cdot \mathrm{kg}^{-1}$, a highly desirable result for citrus nutrition. Despite the initial yield decrease, the alternative treatment showed a higher fruit mass per plant in the last evaluation in August 2004, i.e. 58.2 kg.plant ${ }^{-1}$ against $42.9 \mathrm{~kg}$ plant $^{-1}$ in the conventional treatment, even though fruit size and total acidity were impaired by K deficiency. This shows that, in older aged orchard, an alternative management should be introduced gradually. Subsequent appraisals showed that the alternative treatment provide a better equilibrium in the population of Orthezia praelonga, i.e. $0.54 \%$ of attacked plants against $14.06 \%$ in the conventional treatment. 


\section{INTRODUÇÃO}

O Brasil mantém a posição de maior produtor mundial de laranja desde o início da década de 90, sendo responsável por cerca de 37\% da produção mundial, seguido pelos Estados Unidos (23\%), México (8\%), China (7\%) e Espanha (6\%). O estado de São Paulo responde por 73\% da produção nacional (FNP Consultoria \& Comércio, 2004d).

Atividade altamente importante para o desenvolvimento do Brasil, a citricultura representa $49 \%$ de toda a fruticultura brasileira, ocupa aproximadamente 800 mil hectares de área de plantio (Fundecitrus, 2004a) e a colheita estimada para a safra 2004/2005 é de 350 milhões de caixas de 40,8 kg (FNP Consultoria \& Comércio, 2004d). Em 2003 a citricultura representou 1,87\% da pauta total das exportações brasileiras e 4,47\% das exportações do agronegócio. O principal produto, comercializado no mercado internacional, é o suco de laranja concentrado congelado (FCOJ), que representa $72 \%$ das exportações do setor com movimentos de US\$3,23 bilhões (Fundecitrus, 2004a).

Nos últimos anos a citricultura brasileira vem enfrentando novos desafios.

O avanço da Clorose Variegada dos Citros (CVC), causada pela bactéria Xylella fastidiosa, Morte Súbita dos Citros (MSC), de causa ainda desconhecida, e mais recentemente o Greening, considerada uma doença de difícil controle, que tem como origem mais provável a China e hoje afeta seriamente a produção de citros na Ásia e na África, impõem mais custos e preocupações ao citricultor (FNP Consultoria \& Comércio, 2004b).

Em decorrência desses e de outros eventos fitossanitários mais antigos na citricultura, é crescente o volume aplicado de defensivos e fertilizantes químicos nos 
pomares. A atividade consumiu US\$141 milhões em defensivos e US\$104,84 milhões em fertilizantes e corretivos em 2003 (Fundecitrus, 2004a). Em média, somente a aquisição desses insumos representa, em relação ao custo total de produção, 30\% para os defensivos químicos e 18\% para os fertilizantes (FNP Consultoria \& Comércio, 2004d). Nas tangerinas, a pinta preta (Guignardia citricarpa), doença fúngica que afetou e ainda afeta mais o sul do estado de São Paulo, eleva o custo de produção em US\$ 0,37 para cada caixa de 40,8 kg (FNP Consultoria \& Comércio, 2004c). Logicamente, não estão computados os custos ambientais e os riscos à saúde dos produtores e consumidores.

A despeito disso, cresce cada vez mais a preocupação e o interesse dos consumidores, em especial do mercado externo, em relação à segurança dos alimentos, principalmente no que se refere à forma de produção, bem como as implicações ambientais e sociais do processo produtivo utilizado. Na Europa, a partir de janeiro de 2005, quase metade dos ingredientes ativos utilizados no controle de pragas serão proibidos, inclusive para os produtos oriundos de outros países (Fundecitrus, 2004b). Sistemas de gestão da qualidade com protocolo de boas práticas agrícolas, como o EUREPGAP na Europa e Produção Integrada de Frutas (PIF) no Brasil, que contemplam desde a utilização adequada de agroquímicos, rastreabilidade do produto e os aspectos ambientais e sociais, são claras evidências de que os mercados e os governos estão se adaptando para atender essa nova demanda.

Outra evidência dessa tendência do consumidor é a evolução do mercado de alimentos oriundos de sistemas orgânicos de produção. Nesse sistema é proibida a utilização de pesticidas e fertilizantes químicos, e os aspectos sociais e ambientais devem ser respeitados, sendo tudo regulado por normas e ações fiscalizadoras. O consumo de alimentos orgânicos na Europa, EUA e Japão, têm crescido aproximadamente 25\% ao ano com movimentos na ordem de US\$25 bilhões em 2003 (FNP Consultoria \& Comércio, 2004a). Na citricultura orgânica, o Brasil também se coloca como o maior produtor e exportador de sucos concentrados congelados. A produção de laranja orgânica cresceu 233\% de 1999 para 2000, atingindo 1,5 milhões de caixas (Planeta Orgânico, 2004). 
Essa tendência do mercado consumidor é um processo irreversível e é evidente a necessidade de desenvolvimento e aprimoramento de tecnologias capazes de conciliar as novas exigências com a viabilidade econômica da atividade citrícola.

O objetivo deste trabalho é avaliar as possibilidades de novas alternativas de manejo em citros que permitam, não apenas preservar, mas usufruir das potencialidades dos recursos naturais conciliando-as com a necessidade de ganhos em produtividade da citricultura contemporânea. Para isso, foram utilizados como indicadores, parâmetros importantes para a cultura, como a compactação do solo, as associações micorrízicas, a nutrição e a produtividade da planta. 


\section{REVISÃO DE LITERATURA}

\subsection{Tangor 'Murcott'}

A origem do tangor 'Murcott' (Citrus reticulata Blanco x Citrus sinensis Osbeck) não é bem conhecida. Seu nome é uma homenagem ao viveirista Charles Murcott Smith, que obteve as primeiras plantas enxertadas em Bayview, Flórida, Estados Unidos, em 1922. A variedade foi introduzida no Brasil pelo Instituto Agronômico em 1948 (Figueiredo, 1991).

O tangor 'Murcott' representa 24\% das tangerinas plantadas no Estado de São Paulo sendo a segunda mais cultivada, perdendo apenas para a 'poncã' (Instituto de Economia Agrícola, 2005). É uma variedade mais tardia, portanto, permite obter safras em períodos diferentes das outras tangerinas resultando em melhores preços (Figueiredo, 1991). Seus frutos têm boa aceitação no mercado por apresentar boas características como: tamanho, boa coloração externa e interna, resistência ao transporte, alto rendimento de suco e potencial para industrialização. Entretanto, é uma tangerina mais difícil de ser descascada e possui muitas sementes, características consideradas indesejáveis e pode não ser competitiva em mercados mais exigentes (Borges \& Pio, 2004).

As características das plantas de tangor 'Murcott' são: porte médio, copa ereta e, em média, a produtividade pode atingir $200 \mathrm{~kg}$ de frutos por planta. Se não for manejado com desbastes de fruto associados a uma nutrição adequada, a produção tende a se alternar, em relação ao volume de colheita, de um ano para outro. Os frutos pesam aproximadamente $140 \mathrm{~g}$ e possuem em torno de 20 sementes. É abundante em suco, 48\% do peso do fruto, com teores médios de brix 12,6, acidez 0,92\% e 'ratio' de 13,7 (Figueiredo, 1991). 
O tangor 'Murcott', assim como a maioria dos citros, absorve bastante $\mathrm{N}$ e $\mathrm{K}$ e é exigente nos principais micronutrientes. A planta reage à aplicação de $\mathrm{N}$ aumentando o tamanho de copa, e assim, a produtividade em frutos. O K aumenta o tamanho dos frutos, mas em excesso prejudica a produção, provavelmente pela menor absorção de Ca e Mg (Mattos Junior et al., 2004). Já a deficiência de K pode resultar em frutos pequenos (du Plessis, 1992) e menor tolerância à seca (Marschner, 1995). O B e Zn são os micronutrientes que requerem maior atenção do produtor, portanto, a utilização de fontes de B no solo e de Zn via foliar, é a forma mais recomendável de aplicação (Quaggio et al., 2003).

\subsection{Manejo Alternativo em citros}

O solo, sendo um componente fundamental da produção, imprime variados níveis de facilidade ou dificuldade, dependendo de suas características, para a obtenção de produtividades compatíveis com os níveis de investimento. Portanto, as características dos solos e seus efeitos interativos devem ser bem conhecidos, de forma a permitir que se retire o máximo proveito dos seus parâmetros favoráveis ou se contorne da melhor maneira aqueles que possam atribuir limitações à produtividade agrícola. Baseados nesses parâmetros, é que se poderia definir a combinação de procedimentos e escolha de tecnologias e formular o manejo racional (Mazza et al., 2000).

Toda planta, assim como o citros, depende da vida do solo, da biodiversidade local, da nutrição equilibrada e das condições climáticas. A vida do solo está relacionada ao fornecimento contínuo de matéria orgânica. A sua proteção contra sol, chuva, vento e compactação por trânsito de maquinários dependem de cobertura morta e viva (Sanches, 2000).

$\mathrm{Na}$ visão mais conservadora, os manejos em citros estão centrados em administrar os fatores nutricionais, fitossanitários e culturais do pomar, de maneira isolada, desconsiderando-se as interações que podem ocorrer com o ambiente ou mesmo entre si. Um dos exemplos é a forma de manejo na entrelinha, ainda adotado por muitos citricultores, onde a vegetação que ocorre espontaneamente é vista como invasora e concorrente da cultura principal, hospedeira de pragas e que dificultam os tratos 
culturais. No entanto, tais plantas também precisam ser vistas como importantes contribuintes do agroecossistema. Normalmente são de características pioneiras ocupando locais cuja cobertura natural foi extinta e o solo ficou total ou parcialmente exposto. Além disso, são importantes fontes de matéria orgânica, reciclam nutrientes, sua rizosfera serve de abrigo para microrganismos benéficos, amenizam o microclima local, abrigam insetos polinizadores e predadores de importantes pragas (Durigan \& Pitelli, 1994).

As possibilidades e os benefícios do manejo da cobertura vegetal na entrelinha em pomares cítricos foram estudados por vários autores que observaram efeitos como a proteção do solo contra os impactos da chuva, produção de matéria orgânica, desenvolvimento de agregados, diminuição ou reversão da compactação do solo, melhoria na infiltração de água e o favorecimento ao desenvolvimento do sistema radicular.

Moreira (1992) recomenda que, devido à localização muito superficial das radicelas das laranjeiras, é necessário manejar com muito cuidado o solo do pomar. Assim, o autor ressalta a importância da opção por máquinas e implementos mais leves e de rodado mais largo, associada a um bom planejamento e à substituição de grades por roçadeiras no controle da vegetação espontânea na entrelinha.

O manejo da cobertura vegetal na entrelinha pode ser feito através do plantio de gramíneas, leguminosas ou manejar a própria vegetação espontânea ocorrente na entrelinha. Tersi et al. (1999), testando os efeitos do controle das plantas daninhas através de várias combinações de herbicidas, roçadeiras e grade na linha e entrelinha de um talhão de laranjeira 'Valência' durante quatro safras, verificaram que não houve efeitos prejudiciais na produção e qualidade de frutos das áreas apenas roçadas, em relação às mantidas no limpo com controles mecânicos ou químicos. Dessa forma, os autores concluiram que, do ponto de vista conservacionista e do equilíbrio fitossanitário, o manejo que mantém a cobertura vegetal é a mais promissora. Neves et al. (1998), testando manejos com leguminosas, vegetação espontânea roçada e capina manual na linha e entrelinha de tangerina 'Poncã' (Citrus reticulata Blanco) sobre limão-'cravo' (Citrus limonia) em Latossolo roxo, verificaram que houve maior acúmulo de matéria 
orgânica no solo nas parcelas não capinadas, sem prejuízos à produção, qualidade de frutos e estado nutricional das plantas, abrindo novas perspectivas para o manejo da cobertura vegetal em citros.

Segundo Sanches (2000) a melhor proteção e manutenção das condições ideais de um solo são fornecidas por gramíneas, com preferência às que possam ser perenizadas. A correlação entre a alta densidade e distribuição de raízes de gramíneas perenes no solo e a formação e estabilidade de agregados, também foi observada por Silva e Mielniczuck (1997a) em áreas conduzidas com plantios de trigo/soja e setária (Setaria anceps L.), capim pangola (Digitaria decumbens L.), siratro (Macroptilium citro purpureum L.) e semeadura direta com aveia/milho e área sem vegetação. Os autores concluíram que as gramíneas perenes, dadas as peculiaridades dos mecanismos e ação do seu sistema radicular, podem ser usadas como plantas recuperadoras da estrutura do solo em áreas degradadas. Em outro trabalho, Silva e Mielniczuck (1997b), verificaram que o solo com pastagem nativa apresentava índices de agregação próximos aos valores obtidos na mata nativa, apesar do menor teor de carbono orgânico da primeira, confirmando assim, a capacidade recuperadora de estruturas do solo das gramíneas perenes.

Para Oades (1984), a melhor forma de incorporar matéria orgânica no solo é através das raízes de gramíneas, que são particularmente finas, fasciculadas e extensivas, e essas devem ser manejadas cortando-as em intervalos de tempo suficientes para que haja a recuperação do seu sistema radicular. Dessa maneira, se obtém o máximo de morte e desenvolvimento de novas raízes, que resulta em máximo acréscimo de matéria orgânica no solo, garantindo-se a estabilidade dos macroagregados.

Outra vantagem das gramíneas para esse tipo de manejo foi mostrada por Matheis (2004) que, ao avaliar o efeito produzido pelas coberturas mortas produzidas por plantios de lab-lab (Dolichos lablab), guandú (Cajanus cajans) mais crotalária (Crotalaria juncea) e de milheto (Pennisetum glaucum) comparadas com o capim colonião (Panicum maximum) de ocorrência natural, na entrelinha em um pomar de laranja em produção, concluiu que o último apresentou melhor efeito supressivo sobre as ervas daninhas na linha de plantio. 
Nos pomares do Estado de São Paulo é muito comum a ocorrência de Brachiaria spp que pode ser aplicada como cobertura vegetal. Uma das características que mais motiva sua utilização é a adaptabilidade aos mais diversos ambientes e na maioria dos casos ela ocorre espontaneamente, portanto, sem custo de implantação e manutenção, apesar do temor pela sua agressividade e do suposto efeito alelopático em citros. Forli (2003), pesquisando a possibilidade de exploração simultânea com Brachiaria decumbens para produção de silagem na entrelinha de um pomar de citros, observou que a produtividade, as características tecnológicas e físicas dos frutos, estado nutricional das plantas, atributos químicos do solo da projeção da copa, não foram afetados pelo manejo da braquiária na entrelinha.

Estudos de Rizzo (2000) apontam que as braquiárias são benéficas à estruturação do solo e seus resultados são em médio prazo. Avaliando o efeito das braquiárias em um pomar implantado em áreas de latossolo vermelho escuro, degradadas pela compactação, após 30 e 78 meses, mostrou sua capacidade recuperadora da estrutura do solo, através do crescimento do sistema radicular fasciculado nas fissuras naturais produzidas pela desidratação do perfil e que progressivamente geram os bioporos. No mesmo trabalho, o autor concluiu que, a geração de polissacarídeos resultantes da decomposição da matéria orgânica produzida pela braquiária tem grande efeito na microagregação, principalmente nas camadas superficiais do solo, reabilitando, assim, a estrutura e diminuindo a resistência à penetração das raízes.

Atualmente já se recomenda manejar a fitomassa na entrelinha, com o intuito de aproveitá-la roçando e direcionando-a para a linha de plantio (Mazza et al., 2000; Sanches, 2000) e em alguns casos até com aplicação de fertilizantes sobre a vegetação espontânea para incentivar o processo (Yamada et al., 2000).

O equilíbrio do ecossistema citrícola é sustentado por uma diversidade de fatores, principalmente de ordem biológica, ocorrentes tanto na parte aérea como no solo. Dentre esses, estão os fungos micorrízicos arbusculares (FMA), simbiontes endofíticos que protagonizam a mais antiga e conhecida associação entre vegetais e microrganismos e são bastante influenciados pelo manejo agrícola e insumos aplicados. 


\subsection{Compostos fermentados Bokashi}

O composto fermentado Bokashi é uma mistura de diversos tipos de matéria orgânica farelada submetida à fermentação, predominantemente do tipo láctica. O processo é de origem japonesa e foi desenvolvido e adaptado por Teruo Higa, na Universidade de Ryukyus (Okinawa, Japão), em 1980, e trazido ao Brasil pela Fundação Mokiti Okada, onde já é bem difundido principalmente entre os agricultores nipobrasileiros e entre os praticantes de agricultura orgânica.

Em geral, a fermentação do Bokashi é obtida utilizando-se uma suspensão de microrganismos, o EM (Effective Microrganisms), também desenvolvido por Higa. Conforme Higa (1996), Higa \& Parr (1994) e Sakakibara (1998), o EM é constituído de culturas mistas de microrganismos benéficos, tais como bactérias lácticas, leveduras, actinomicetos e outros ocorrentes naturalmente no ambiente. Na confecção do Bokashi esses microrganismos agem sobre a matéria orgânica fermentando-a ocorrendo produção de ácidos orgânicos, vitaminas, enzimas, aminoácidos e polissacarídeos interessantes ao desenvolvimento vegetal (Higa \& Wididana, 1991).

Panchaban (1991) relatou sobre os microrganismos fermentadores e suas relações sinergísticas com outros microrganismos benéficos, tais como Azotobacter e fungos micorrízicos arbusculares (FMA). A aplicação de matéria orgânica adicionada com EM influenciou positivamente o desenvolvimento de fungos micorrízicos arbusculares em grão-de-bico (Cicer arietinum L.), segundo Bajwa et al (1998). Higa \& Kinjo (1991) verificaram aumento na população de fungos, bactérias e actinomicetos em solo, quando aplicadas bactérias fermentadoras lácticas junto com a matéria orgânica. De acordo com Zhao (1998), a aplicação de matéria orgânica acrescida de EM, incrementou em $50 \%$ a população de bactérias, fungos, actinomicetos e microrganismos fixadores de nitrogênio no solo, quando comparado com matéria orgânica não acrescida de EM. Valarini et al. (2003) observaram que, com a aplicação de matéria orgânica de origem animal e vegetal acrescida de EM, a atividade biológica do solo foi potencializada, contribuindo para o processo de humificação.

No Brasil o Bokashi é fabricado e distribuído comercialmente pela empresa Korin Agropecuária Ltda, sob as marcas NUTRI BOKASHI e GARDEN 
BOKASHI. Os produtos são formulados basicamente a partir de subprodutos agroindustriais, tais como farelos e torta de arroz, soja e mamona. A recomendação é a aplicação na ordem de 80 a 100 gramas para cada metro quadrado cultivado, tanto no preparo da área, bem como em aplicações suplementares, sempre de forma bem espalhada na superfície do solo. Em culturas perenes, assim como o citros, devem ser aplicados em área total, abrangendo linha e entrelinha, compatibilizando-as com o manejo da vegetação espontânea ocorrente. Ou seja, a aplicação ocorre quando a vegetação da entrelinha estiver a ponto de ser roçada (KORIN, 2004).

Há também a opção de se confeccionar um extrato aquoso a partir do produto GARDEN BOKASHI, que consiste em extrair um “caldo”, através da imersão do produto em água por 12 horas. O extrato deve ser diluído e pulverizado na parte aérea das plantas na concentração final de 500 gramas de produto para cada 100 litros de água. A indicação é para fornecer nitrogênio, através dos aminoácidos extraídos durante a imersão, bem como o conjunto de bactérias e leveduras contidas no produto (KORIN, 2004).

Os extratos líquidos confeccionados a partir de matérias orgânicas fermentadas, também conhecidas como biofertilizantes, têm sido amplamente utilizados pelos agricultores orgânicos, com a intenção de se obter efeitos de fitoestimulação, fertilização via foliar, prevenção de doenças e pragas dentre outros. Existem diversas formas e fórmulas de biofertilizantes, sendo as mais conhecidas os fermentados aquosos ativados por bactérias obtidas a partir de esterco fresco de bovino, terras de mata virgem e microrganismos eficazes (EM).

Sartori (2003), avaliando o efeito de biofertilizantes, calda bordalesa, calda sulfocálcica e fungicidas químicos sobre a comunidade de fungos endofíticos e epifíticos e leveduras em folhas e frutos de macieiras de 3 sistemas de produção (convencional, produção integrada e orgânica), observou que os fungicidas químicos exercem forte inibição sobre a população microbiana, em menor grau as caldas e quase que de forma insignificante os biofertilizantes. O mesmo autor também verificou que o Colletotrichum gloeosporioides submetido à presença de isolados de leveduras "in vitro”, formou menor número de colônias do que a testemunha, abrindo perspectivas 
para o desenvolvimento de insumos com tal raciocínio para aplicação em programas de controle biológico de fungos fitopatogênicos.

As leveduras são muito comuns no meio ambiente e se desenvolvem em vários substratos desde o solo até o filoplano, fazendo parte da microbiota epifítica e endofítica. São ativas consumidoras de nutrientes, o que as tornam antagonistas competitivas em relação a outros microrganismos, sendo, portanto, bastante interessantes para a pesquisa do biocontrole de fitopatógenos (Valdebenito-Sanhueza, 2000).

\subsection{Compactação do solo}

Compactação do solo são alterações no arranjo das partículas do solo condicionadas por fatores internos, como textura, estrutura, alternância de secagem e umedecimentos, e externos, como o tráfego de máquinas e implementos, principalmente quando efetuado em determinadas condições de umidade. A compactação, geralmente, diminui o volume ocupado por determinada massa de terra e o tamanho dos macroporos do solo, que permitem livre circulação de ar e água. Por conseguinte, modifica os atributos físicos do solo, como aeração, temperatura e resistência mecânica à penetração, que afetam a disponibilidade dos nutrientes para as plantas, as condições do solo para desenvolvimento de microrganismos e a região ocupada pelas raízes, a rizosfera (Camargo \& Alleoni, 1997).

Em citros, o manejo mecânico adotado pelos produtores no controle do mato e o trânsito exagerado de máquinas, são os principais contribuintes para a compactação do solo. Em um ano agrícola, a freqüência comum de quinze passadas de trator para a realização de operações, como adubações e pulverizações, pode intensificar ainda mais a degradação da estrutura do solo em áreas citrícolas (Stolf, 1987; Tersi \& Rosa, 1995). Lima et al. (2004) detectaram níveis crescentes de compactação na ordem: linha, entre rodado, rodado das máquinas e implementos e projeção da copa das plantas cítricas, respectivamente, em estudo sobre a heterogeneidade na compactação, provocada por diferentes intensidades de tráfego, em latossolo vermelho amarelo de um pomar de laranja. 
Os danos diretos da compactação do solo são: aumento da resistência à penetração radicular, redução da aeração, alteração do fluxo de água e calor e da disponibilidade de água e nutrientes (Camargo \& Alleoni, 1997). A organização e interação das partículas coloidais determinando a quantidade e proporcionalidade entre os macro e microporos e seus reflexos nas curvas de retenção de umidade, têm importância fundamental no desenvolvimento do sistema radicular da cultura cítrica (Mazza et al. 2000).

Dessa forma, além do uso racional dos maquinários e implementos, é recomendada a adoção de manejos de solo e da matéria orgânica que, não somente minimizem o impacto das operações, mas também agreguem outras vantagens tais como: proteger o solo dos impactos da chuva, produzir matéria orgânica, desenvolver agregados, diminuir ou reverter a compactação, melhorar a infiltração de água e assim favorecer o desenvolvimento do sistema radicular (Sanches, 2000).

Em situações de áreas compactadas o primeiro passo é conhecer a intensidade e a localização do problema. Camargo e Alleoni (1997) destacam basicamente quatro formas de reconhecimento e medida da compactação do solo: a) densidade do solo ou porosidade; b) infiltração de água; c) resistência à penetração e; d) exame de trincheiras. A densidade do solo é o método mais indicado por ser menos influenciado por fatores externos, como a umidade, segundo o autor. Ao contrário, a infiltração de água e a resistência à penetração são sensíveis ao estado de umidade do solo. Já o exame de trincheiras é mais recomendado para avaliar o perfil do solo ao final de uma safra.

O método da resistência à penetração tem como vantagem a forma rápida e fácil de avaliar o estado de compactação do solo em várias profundidades. O equipamento comumente utilizado para tal avaliação é o penetrômetro de impacto, que utiliza um peso de curso constante para provocar a penetração da haste no solo através de impactos. Este equipamento, diferentemente do penetrômetro convencional, também conhecido como penetrógrafo, não possui um dinamômetro com registrador e os resultados são obtidos diretamente através do cálculo da quantidade de impactos para 
cada decímetro penetrado pela haste no solo, expressado em impactos.dm ${ }^{-1}$ (Stolf et al., 1983), ou pela sua conversão para uma unidade de força, em $\mathrm{kgf.cm}^{-2}$ (Stolf, 1991).

A limitação do método é de somente ser válido para um mesmo local sem variações de solo e à mesma umidade, tanto que é recomendada a apresentação dos dados de umidade do solo, juntamente com os dados da resistência à penetração (Camargo \& Alleoni, 1997).

\subsection{Densidade radicular superficial}

As plantas cítricas necessitam de um bom desenvolvimento do sistema radicular que, ao explorar um maior volume de solo, suprirão mais adequadamente suas necessidades de água e nutrientes e assim manifestarão o seu potencial produtivo.

A distribuição das raízes das plantas varia com as espécies, cultivares, idade, características químicas e físicas do solo, os tratos culturais e as condições fitossanitárias. O estudo do sistema radicular das espécies vegetais utilizadas na agricultura, sua distribuição, extensão e atividade, é de fundamental importância para o entendimento científico da produção agrícola, pois fornece informações sobre localização de adubação, espaçamento, culturas intercalares, manejo do solo e irrigação (Fracaro \& Pereira, 2004)

Na citricultura esse assunto tem sido pesquisado por alguns autores. De acordo com estudos de Moreira (1983) em uma laranjeira 'Pêra', sob porta enxerto de limão ‘Cravo' e cultivado em transição de latossolo vermelho amarelo para latossolo roxo, $50 \%$ das radicelas se encontram na profundidade de 0 a $15 \mathrm{~cm}$ e dessas a maior parte está na faixa entre 1,40 e 3,50 m de distância do tronco. Oliveira et al. (1998), com objetivo de conhecer a distribuição do sistema radicular para subsidiar projetos de irrigação em citros, realizaram trabalho com laranja 'Pêra' sobre porta enxerto de tangerina 'Cleópatra' em solo franco arenoso e estimaram em 0,60 m a profundidade efetiva (Pe) das raízes, que se define como a profundidade onde se encontra, pelo menos, 80\% (em peso) do total das raízes. A distância efetiva (De), ou seja, distância a partir do tronco da planta onde também se encontra, pelo menos, 80\% (em peso) do total das 
raízes, foi estimada em 1,65 m. Os autores também observaram que 65,4\% das raízes se localizam nos primeiros $0,25 \mathrm{~m}$ da superfície do solo.

Conhecida a importância das raízes para o bom desempenho produtivo do citros é necessário saber quais fatores causam restrições ao desenvolvimento do sistema radicular e como saná-las. Segundo Demattê \& Vitti (1992), dentre os tipos de restrições que podem ocorrer ao desenvolvimento radicular destacam-se as de natureza física e química. A primeira seria devido à condição física do solo, que estando compactado e com baixa capacidade de drenagem dificulta o crescimento radicular. Essa condição pode ser ocasionada pelo manejo incorreto do solo ou pela sua própria natureza. A restrição química está relacionada à baixa fertilidade do solo e ao nível de alumínio elevado. Outros fatores que também influenciam o desenvolvimento radicular são: suprimento de carboidrato pela planta, morfologia da raiz, atuação hormonal, fórmulas e formas de adubação, microrganismos benéficos ou patogênicos na rizosfera, presença de substâncias fitotóxicas, como as que podem ser produzidas pela forma inadequada de decomposição da matéria orgânica, temperatura e umidade do solo (Marschner, 1995).

Em citros, o manejo mecânico adotado pelos produtores no controle do mato e o trânsito exagerado de máquinas no pomar, são os fatores de maior contribuição para a compactação do solo e, consequentemente, estariam prejudicando o desenvolvimento radicular. De acordo com Camargo \& Alleoni (1997), como a compactação provoca diminuição no tamanho dos poros, a ponto de impedir a passagem da raiz principal, a planta lança mão do mecanismo de defesa via expansão de raízes laterais com diâmetros adequados para passar por eles. Essas raízes laterais parecem responder à imposição de obstáculos mecânicos de maneira muito semelhante à raiz principal. Assim, se o obstáculo é imposto a ambas, todo o sistema se tornará definhado.

Carvalho et al. (1999) observaram a influência exercida pelos tipos de manejo do mato em pomar cítrico sobre o desenvolvimento radicular. Estudando a laranja 'Pêra' sobre limão ' Cravo', em regiões produtoras nos Estados da Bahia e Sergipe, entre 1993 e 1996, observaram um incremento de 146,8\% e 68,8\% na área radicular e $28,2 \%$ e 40,2\% em produção, respectivamente nos dois locais, quando manejada com cobertura vegetal utilizando feijão de porco (Canavalia ensiformis), 
associado com subsolagem na entrelinha e herbicida na linha, em relação às áreas mantidas no limpo através de 3 capinas manuais na linha e 3 gradagens na entrelinha por safra.

Uma das condições fundamentais para se avaliar o sistema radicular é conhecer o seu volume e distribuição. Böhm (1979) se refere aos principais métodos para estudo de raízes aplicáveis em campo como tediosos, demorados e frequentemente seus resultados não são muito exatos. Os métodos podem ser agrupados da seguinte forma: método da escavação (exposição total do sistema radicular); método do monolito (retirada de blocos de solo que são lavados e peneirados para separação das raízes); método do trado (retirada de solo com raízes com uso de trado); método da trincheira (abertura de trincheira e exposição das raízes); método da parede de vidro (colocação inclinada de uma janela de vidro em trincheira e observação do crescimento radicular) e métodos indiretos (avaliação de parâmetros que se correlacionam com o desenvolvimento radicular como a água do solo).

Köpke (1981) avaliou quatro métodos de campo para determinação do desenvolvimento radicular, que considera ser os principais, discutindo suas vantagens e limitações. O método do monolito determinou a maior densidade de raiz-comprimento ( $\mathrm{cm}$ raiz. $\mathrm{cm}^{-3}$ de solo) se comparado aos outros. O método é bastante exato, entretanto, é demorado e tedioso em alguns casos. O método do perfil se mostrou menos trabalhoso, porém, subestima os valores se comparado ao método do monolito. O método do trado também é menos trabalhoso e permite número maior de repetições, o que o favorece estatisticamente. O método do tubo permite acompanhar a taxa de crescimento de raízes.

Moreira (1983) e Oliveira et al. (1998) utilizaram o método do trado para avaliação do sistema radicular de laranja 'Pêra’ em porta enxerto de limão 'Cravo’ e tangerina ‘Cleópatra’, respectivamente, atestando sua praticidade e eficácia.

Outro método, mais recentemente aplicado, para avaliação do sistema radicular é o processamento de imagens digitais. Esse método propõe avaliar a distribuição de raízes que ocorrem em um perfil de solo, substituindo a usual quantificação visual, feita mediante quadros reticulados. A determinação da densidade de raízes é obtida por meio de algumas etapas de filtragem da imagem e calibração de 
um 'software', o SIARCS (Sistema Integrado para Análise de Raízes e Cobertura do Solo), especialmente desenvolvido que calcula através do nível de cinza de cada pixel (Crestana et al., 1994).

Neves et al. (2000) compararam os resultados do método de avaliação do sistema radicular, em citros, utilizando o processo por tratamento de imagens (SIARCS) com os valores determinados a partir do peso seco da mesma amostra e concluiu que o comprimento e a área de raízes, determinados por imagens digitalizadas, fornecem uma boa estimativa da quantidade de raízes presentes no perfil.

\subsection{Associação micorrízica}

\subsubsection{Fungos micorrízicos}

Micorriza é a associação mais comum entre microrganismos e raízes de plantas superiores no mundo. Nesse processo, fungos específicos colonizam as raízes das plantas, captam nutrientes do solo, através da rede de hifas externas, e os transferem à planta hospedeira em troca de substrato energético (fotoassimilados), ocorrendo uma perfeita integração morfológica e funcional, estabelecendo-se uma inter-relação biotrófica. Essa associação mutualística desempenha papel importante no ambiente, contribuindo para a evolução e sobrevivência das comunidades vegetais (Silveira, 2000).

De forma global, a associação micorrízica ocorre na maioria dos vegetais, desde briófitas e pteridófitas até gimnospermas e angiospermas. É encontrada na maioria das espécies de interesse agrícola, principalmente nas famílias Solanaceae, Gramineae e Leguminosae. As exceções ficam para as Brassicaceae, Fumariaceae, Uticaceae, Cyperaceae e Juncaceae, que não formam micorrizas (Silveira, 1992). Têm ampla distribuição geográfica, estando presentes em regiões tropicais, temperadas, áreas cultivadas, florestas, savanas, dunas e desertos (Silveira, 2000). Basicamente, estão divididas em dois grupos, de acordo com a forma de relacionamento do seu micélio com a estrutura radicular do hospedeiro, sendo as endomicorrizas e as ectomicorrizas. As endomicorrizas se alojam dentro das células corticais das radicelas e também nos espaços intercelulares. Os mais comuns e conhecidos são os fungos micorrízicos arbusculares (FMA). Já, as ectomicorrizas ocorrem principalmente em raízes de espécies 
madeireiras e se caracterizam pela colonização externa onde os micélios formam uma espécie de manta entrelaçada de hifas na superfície radicular (Smith \& Read, 1996).

Em geral, os FMAs são fortemente ou completamente dependentes das plantas superiores para sobreviverem, que por sua vez, nem sempre se beneficiam dessa relação (Marschner, 1995). Somente em alguns casos, como nas orquídeas, a associação micorrízica é essencial para a hospedeira (Silveira, 1992; Smith \& Read, 1996). A micorrização pode ser mínima ou mesmo não ocorrer em algumas situações, como em solos demasiadamente secos, salinos, alagados (ex.: pântanos), severamente perturbados (ex.: extração de minérios) ou com fertilidade extremamente alta ou baixa, (Smith \& Read, 1996).

Os FMAs são mais conhecidos pelo incremento no suprimento de nutrientes minerais de baixa mobilidade no solo para as plantas, em especial o P. As hifas externas capturam, absorvem e translocam o P de zonas onde as raízes das plantas hospedeiras não alcançam. Também há maior eficácia na absorção de $\mathrm{K}, \mathrm{Zn}$ e Cu, e foram constatados maiores teores de $\mathrm{N}, \mathrm{Ca}, \mathrm{Mg}$ e $\mathrm{S}$ na parte aérea de plantas micorrizadas (Marschner, 1995). Também, atua na relação água-planta, conferindo a planta maior tolerância ao estresse hídrico (Smith \& Read, 1996), como bioprotetores contra o ataque de fitopatógenos pelas raízes e estresse por substâncias tóxicas (Jeffries et al., 2003) e contribuem para a estruturação do solo através de suas hifas, que participam na agregação das partículas do solo e na sua estabilização (Nóbrega et al., 2001).

Sua importância cresce nos solos pobres das regiões do trópico úmido, onde o nível de $\mathrm{P}$ e de micronutrientes são fatores limitantes para o crescimento e a produção vegetal. Geralmente, as plantas nativas desses locais são altamente dependente das associações com FMAs para se desenvolverem (Silveira, 1992; Smith \& Read, 1996). Estudos indicam que os FMAs atuam na estabilização do fluxo nutricional do ecossistema através dos gradientes edáficos e de forma funcional compensam as amplas variações na fertilidade do solo (Barea \& Jeffries, 1995).

A relação entre os FMAs e as plantas hospedeiras pode ser mutualística, neutra ou parasítica, dependendo das circunstâncias. Apesar de comumente ser citado 
como simbiose, devido a predominância do mutualismo, associações onde os FMAs assumem posturas neutras ou parasíticas não são raras. De forma geral, as plantas possuem pouco domínio sobre o controle dos níveis de infecção radicular, desenvolvimento e competição por carboidratos dos fungos (Smith \& Read, 1996). A associação pode ser considerada parasítica quando o custo para a planta hospedeira se tornar maior do que o benefício retornado, que pode ser induzido por fatores genotípicos ou ambientais, influenciado pelas características morfológicas, fenológicas e fisiológicas de cada hospedeiro (Johnson et al., 1997).

Em campos cultivados, o efeito parasítico dos FMAs pode surgir, quando a disponibilidade de nutrientes é muito elevada, principalmente do P. Segundo Peng et al. (1993), em plantas micorrizadas submetidas a altas dosagens de P, há um aumento significativo de ácidos graxos nas raízes fibrosas, que estaria diretamente ligado com o alto dispêndio em $\mathrm{C}$ para produção de novas raízes, devido ao consumo também pelos FMAs, deprimindo, assim, o desenvolvimento da parte aérea.

\subsubsection{Associação micorrízica arbuscular em citros}

As possibilidades de contribuições que os fungos micorrízicos arbusculares (FMA) têm a oferecer para a cultura do citros são significativas. Os citros apresentam alta dependência micorrízica na absorção dos nutrientes P, K, S, Fe, Mn e Zn e quando submetidos a teores adequados de $\mathrm{P}$, as plantas micorrizadas respondem nutricionalmente melhor dos que as não micorrizadas para o mesmo nível de P (Cardoso et al., 1986; Melloni \& Cardoso, 1996). Um dos fatores determinantes para essa dependência é o reduzido sistema radicular dos citros, bastante deficiente em pelos absorventes (Cardoso \& Freitas, 1992; Paul \& Clarck, 1989).

Os resultados são bastante significativos quando os FMAs são aplicados na formação de mudas, chegando a provocar incrementos no seu desenvolvimento, tanto em altura, diâmetro do caule, como em matéria seca da parte aérea, permitindo a antecipação da enxertia (Melloni et al., 2000).

Resultados assim, normalmente, são obtidos em baixas dosagens de P, entretanto, pode haver uma inversão no desempenho se houver adubação fosfatada 
pesada. Gomes \& Cardoso (1997) observaram que a partir de $200 \mathrm{mg}^{\mathrm{kg}} \mathrm{kg}^{-1}$ de P, os portas enxertos micorrizados tiveram seu comprimento do micélio externo ativo (MEA) reduzidos e o comprimento do micélio total (MET) aumentados. Segundo os autores, esse fato pode ser uma das causas da redução no crescimento das plantas micorrizadas e cultivadas em substratos com elevados teores de P, que teriam seus fotoassimilados consumidos pelo dreno de C para os micélios extrarradiculares do fungo, sem, no entanto, obter benefícios em troca. Graham \& Eissenstat (1998) evidenciaram o custo em C através da aplicação de benomyl na área radicular de citros sobre diversos porta enxertos em condições de campo. Quando bem abastecido de P a aplicação de benomyl, indiretamente, promoveu o melhor desenvolvimento da parte aérea, devido à redução dos índices de colonização radicular. Gomes \& Cardoso (1997) também verificaram que a partir de 400 mg.kg-1 de P não houve mais colonização de FMAs e a partir de 600 mg. $\mathrm{kg}^{-1}$ a absorção de macro e micronutriente tendeu a cair.

Ainda é deficiente a quantidade de informações precisas sobre os benefícios dos FMAs em citros sob condições de campo. Espeleta et al. (1998) verificaram que em condições de estresse hídrico as raízes de citros que se encontravam $20 \%$ colonizadas com FMAs, apresentaram 10\% menos de mortalidade em relação às que não estavam micorrizadas.

\subsubsection{O manejo agrícola e os FMAs nativos}

Os resultados apresentados pelos diversos trabalhos de pesquisas com FMAs possibilitam estimar a enorme potencialidade de benefícios que essa associação traria à produção vegetal e ao meio ambiente, pela possibilidade de economia de fertilizantes químicos e defensivos agrícolas, se já fosse possível aplicá-las em campo nas principais culturas econômicas (Barea \& Jeffries, 1995).

Ainda não se pode fazer expectativas em torno da utilização de inóculos de FMAs selecionados, pois os conhecimentos sobre o funcionamento dos FMAs em condições de campo ainda são insuficientes (Marschner, 1995). Pesquisas recentes sobre a aplicabilidade das associações micorrízicas na agricultura têm revelado que ainda há várias lacunas no conhecimento sobre a biologia e ecologia do fungo (Aryal \& Xu, 
2000). Aparentemente, os benefícios efetivos dos FMAs na produção agrícola são mais promissores em circunstâncias cuja infecção potencial dos fungos nativos é manipulada indiretamente através de manejos de solos e rotação de culturas (Marschner, 1995). Assim, os efeitos dos manejos e das práticas agronômicas sobre a comunidade nativa dos FMAs precisam ser mais pesquisados (Aryal \& Xu, 2000).

O manejo agrícola é determinante no estabelecimento e desempenho dos FMAs nativos, pois vários fatores interferem, positiva ou negativamente, na infectividade do fungo e na eficiência da associação, tais como: $\mathrm{pH}$, nível de fertilidade (em especial disponibilidade de P), umidade, aeração, luminosidade, temperatura, aplicação de agroquímicos, manejo do solo e culturas, grau de dependência micorrízica da planta e interações entre fungos e outros organismos do solo (Silveira, 2000). Assim, práticas como revolvimento excessivo do solo, encharcamento, queimadas, adubações pesadas e desequilibradas de NPK, monocultura e uso de determinados pesticidas, refletem negativamente na comunidade de FMAs no cultivo agrícola (Kurle \& Pfleger, 1994).

Oliveira \& Sanders (1999) verificaram menores índices de colonização radicular e densidades de esporos de FMAs em solos submetidos a distúrbios mecânicos ou mantidos nu. Adubações pesadas de N e P podem contribuir para a inibição da colonização micorrízica e se, além disso, houver elevados níveis de carbono no solo somado com alta CTC, podem afetar também a abundância de esporos, conforme relatos de Miller \& Jackson (1998).

Dentre os pesticidas as influências variam conforme as funções do produto, os ingredientes ativos e os tipos de fungos micorrízicos. O estudo mais abrangente foi elaborado por Trappe et al (1984) que levantou o efeito de diversos ingredientes ativos de fungicidas, herbicidas, inseticidas e nematicidas sobre a formação e o desenvolvimento de ecto e endomicorrizas, bem como suas produções de esporos. Os fungicidas são os que apresentam interferências mais significativas. Graham \& Eissenstat (1998) constataram a redução da colonização micorrízica e o P absorvido em laranja sobre quatro tipos de porta enxertos provocados pela aplicação do benomyl. Efeitos negativos dos ingredientes ativos de fungicidas benomyl, fosetyl-Al e metalaxyl 
sobre o crescimento radicular e da parte aérea em cebola (Allium cepa L.), o desenvolvimento dos FMAs, os micélios extrarradiculares e a absorção e transferência de P, foram observados por Sukarno et al. (1993), Sukarno et al. (1996) e Sukarno et al. (1998).

Outros autores constataram os efeitos dos fungicidas sobre os FMAs. Foi verificado que houve redução na atividade da fosfatase alcalina nos micélios externos de FMAs em pepinos (Cucumis sativus L.) por propiconazole e também nos micélios internos por fenpropimorph (Kjoller \& Rosendahl, 2000), queda na abundância de esporos e a colonização micorrízica em ervilhas (Pisum sativum L.) por benomyl, PCNB e captan (Schreiner \& Bethlenfalvay, 1996), interferência sobre o transporte de P e a atividade de succinato desidrogenase em micélio externo de FMAs em ervilhas (Pisum sativum L.) por carbendazim e propiconazole (Kling \& Jakobsen, 1997).

Os benefícios auferidos pelas práticas agrícolas com enfoque mais ecológico sobre os FMAs e a importância disso no alicerçamento da sustentabilidade agrícola também foram estudados. Boddington \& Dodd (2000), testando o efeito do manejo agrícola sobre os FMAs nativos em uma área de produção, verificou que a perturbação sobre a densidade de esporos, diversidade de espécies e comprimento de micélio extra radicular é menor em áreas de manejo agroflorestal, quando comparado com o sistema intensivo e monocultural. Segundo Eriksson (2001) em agroecossistemas mais diversificados e com baixo nível de interferências por práticas agrícolas, os índices de colonização micorrízica são bem maiores do que em situações contrárias. Além disso, cultivos rotacionados ou consorciados e manejos conservacionistas, como o uso de cobertura morta ou adubações verdes também promovem a comunidade de FMAs (Miller \& Jackson, 1998; Jordan et al., 2000).

Tudo indica que a constância do ambiente favorece a maior colonização micorrízica, pois há maior diversidade de espécies hospedeiras favorecendo o estabelecimento dos FMAs (Eriksson, 2001). Por outro lado, segundo Sanders et al. (1995) os FMAs podem influenciar nas interações entre plantas e dessas para com outros componentes da comunidade aérea e subterrânea, portanto, acabam por influenciar a estrutura da comunidade vegetal. Similarmente, a natureza da comunidade de plantas, 
dos quais os fungos dependem para obter os fotoassimilados, também podem influenciar a estrutura da comunidade de FMAs. Para Jordan et al. (2000), há evidências consideráveis para sugerir que os FMAs podem alterar a natureza e a diversidade da vegetação espontânea (mato) nos agroecossistemas, incluindo alterações na abundância das espécies micotróficas. Em muitas espécies a associação com FMAs aumenta a capacidade reprodutiva, devido a maior produção de flores ou sementes resultante do melhor desenvolvimento vegetal em conseqüência do incremento na absorção de $\mathrm{P}$ (Sanders et al., 1995). Esse fenômeno é muito importante para as espécies vegetais nativas, especialmente aqueles cuja perpetuação depende das altas taxas de reprodução, como as anuais de ciclo curto (Koide \& Dickie, 2002).

Esse efeito muda a composição da vegetação espontânea e é bastante plausível que a interação com FMAs venha a viabilizar os efeitos benéficos dessa vegetação no funcionamento do agroecossistema, incrementando seus efeitos positivos sobre a qualidade do solo e dos organismos benéficos. Podem também, limitar a expansão das espécies desinteressantes, como as ruderais não micotróficas, reduzindo assim os supostos danos provocados pela competição do mato em relação à cultura econômica (Jordan et al., 2000). O efeito benéfico dos FMAs sobre a composição e funcionamento da comunidade de plantas espontâneas poderão prover uma nova base ecológica para o manejo do mato na agricultura.

A presença de matéria orgânica, bem como sua adequada aplicação, é fundamental para o desenvolvimento dos FMAs. Para Costa (1985) o principal efeito biológico atribuído à matéria orgânica é o de fornecer energia e nutrientes aos microrganismos. Segundo Durigan \& Pitelli (1994) o mato é um importante fornecedor de matéria orgânica no agroecossistema contribuindo para os microrganismos benéficos do solo. A abundância de esporos de FMAs no solo foi fortemente correlacionada com a diversidade de culturas e a ocorrência de matos nos estudos de Miller \& Jackson (1998). Para se beneficiar com o mato os manejos terão que ser adaptados e planejados para cada tipo de cultura de forma a incentivar a diversidade e abundância de FMAs (Jordan et al., 2000). 


\section{MATERIAL E MÉTODOS}

\subsection{Instalação do experimento}

\subsubsection{Caracterização do local}

A instalação do experimento iniciou-se em fevereiro de 2002 envolvendo uma área de aproximadamente 2 hectares de um pomar comercial de tangor 'Murcott', sobre porta enxerto limão cravo ( Citrus limonia Osbeck), espaçamento 7,0 m x 4,0 m, com 10 anos de implantação, na área do talhão 14-A da Fazenda Santo Antonio, situado no município de Araras, Estado de São Paulo. O solo é do tipo latossolo vermelho amarelo, textura arenosa, de fertilidade média (Tabela 1), com topografia suave e levemente inclinada para o sentido leste. O clima local é classificado como do tipo Cwa, mesotérmico, com verões quentes e úmidos e invernos secos, pela classificação de Köeppen. Os registros de precipitação e temperatura, referentes ao período do experimento, foram obtidos no Centro de Ciências Agrárias da Universidade Federal de São Carlos - CCA/UFSCAR, campus Araras, SP, distante em torno de 25 km, em linha reta, da Fazenda Santo Antonio (Figura 1).

\subsubsection{Delineamento experimental}

O objetivo do trabalho foi avaliar o efeito do manejo Alternativo em um campo de tangor 'Murcott' em produção, cultivado de forma convencional. Prevendo que parcelas pequenas, distribuídas aleatoriamente dentro da área experimental gerariam resultados mascarados pelas interferências dos tratamentos das parcelas vizinhas, optouse pela distribuição do tratamento Alternativo em uma área única de 1 hectare, dentro de um talhão de 5 hectares, sendo esta comparada com área contígua e equivalente. Dessa 
Tabela 1. Análise de fertilidade de solo dos tratamentos, Convencional e Alternativo, em Tangor Murcott, amostradas nos meses de agosto nos anos de

\begin{tabular}{|c|c|c|c|c|c|c|c|c|c|c|c|c|c|}
\hline & \multirow[b]{3}{*}{ Unidades } & \multicolumn{4}{|c|}{2002} & \multicolumn{4}{|c|}{2003} & \multicolumn{4}{|c|}{2004} \\
\hline & & \multicolumn{2}{|c|}{ Convencional } & \multicolumn{2}{|c|}{ Alternativo } & \multicolumn{2}{|c|}{ Convencional } & \multicolumn{2}{|c|}{ Alternativo } & \multicolumn{2}{|c|}{ Convencional } & \multicolumn{2}{|c|}{ Alternativo } \\
\hline & & Linha & Entrelinha & Linha & Entrelinha & Linha & Entrelinha & Linha & Entrelinha & Linha & Entrelinha & Linha & Entrelinha \\
\hline MO & g.dm ${ }^{-3}$ & 22 & 22 & 21 & 21 & 26 & 25 & 27 & 27 & 25 & 23 & 21 & 23 \\
\hline $\mathrm{pH}$ & $\mathrm{CACl}_{2}$ & 6,4 & 5,6 & 6,4 & 5,5 & 6,0 & 5,6 & 6,0 & 5,6 & 6,0 & 5,5 & 5,8 & 5,7 \\
\hline$P$ & $\mathrm{mg} \cdot \mathrm{dm}^{-3}$ & 47 & 9 & 36 & 7 & 27 & 9 & 47 & 7 & 46 & 13 & 49 & 17 \\
\hline $\mathrm{Ca}$ & $\mathrm{mmol}_{\mathrm{c} .} \mathrm{dm}^{-3}$ & 38 & 26 & 35 & 23 & 51 & 30 & 50 & 35 & 49 & 26 & 40 & 28 \\
\hline $\mathrm{Mg}$ & $\mathrm{mmol}_{\mathrm{c} .} \mathrm{dm}^{-3}$ & 12 & 10 & 10 & 8 & 11 & 8 & 13 & 6 & 12 & 9 & 14 & 11 \\
\hline $\mathrm{K}$ & $\mathrm{mmol}_{\mathrm{c} .} \mathrm{dm}^{-3}$ & 3,1 & 2,2 & 2,5 & 2,3 & 2,0 & 1,2 & 1,4 & 1,5 & 3,6 & 1,8 & 2,5 & 2,1 \\
\hline $\mathrm{H}+\mathrm{Al}$ & $\mathrm{mmol}_{\mathrm{c} .} \mathrm{dm}^{-3}$ & 11 & 21 & 13 & 25 & 18 & 22 & 16 & 22 & 15 & 22 & 16 & 22 \\
\hline $\mathrm{Al}$ & $\mathrm{mmol}_{\mathrm{c} .} \mathrm{dm}^{-3}$ & 1 & 1 & 1 & 1 & 0 & 0 & 0 & 0 & 0 & 0 & 0 & 0 \\
\hline SB & $\mathrm{mmol}_{\mathrm{c} .} \mathrm{dm}^{-3}$ & 53,0 & 38,0 & 48,0 & 33,0 & 64,0 & 39,2 & 64,4 & 42,5 & 64,6 & 36,8 & 56,5 & 41,1 \\
\hline СТC & $\mathrm{mmol}_{\mathrm{c} .} \mathrm{dm}^{-3}$ & 64,0 & 59,0 & 61,0 & 58,0 & 82,0 & 61,2 & 80,4 & 64,5 & 79,6 & 58,8 & 72,5 & 63,1 \\
\hline V & $\%$ & 83 & 65 & 79 & 57 & 78 & 64 & 80 & 66 & 81 & 63 & 78 & 65 \\
\hline$B$ & mg.dm & 0,40 & 0,28 & 0,38 & 0,37 & 0,11 & 0,00 & 0,11 & 0,11 & 0,40 & 0,11 & 0,39 & 0,52 \\
\hline $\mathrm{Cu}$ & mg.dm & 5,7 & 3,5 & 5,0 & 5,0 & 3,5 & 2,4 & 3,8 & 2,7 & 0,9 & 1,4 & 1,7 & 1,1 \\
\hline $\mathrm{Fe}$ & mg.dm & 30 & 54 & 31 & 58 & 18 & 40 & 26 & 37 & 34 & 30 & 47 & 46 \\
\hline $\mathrm{Mn}$ & mg.dm & 8,7 & 8,3 & 10,9 & 6,6 & 5,7 & 6,1 & 7,3 & 5,0 & 2,0 & 1,8 & 7,2 & 1,2 \\
\hline $\mathrm{Zn}$ & mg.dm & 3,9 & 1,8 & 2,7 & 2,0 & 1,8 & 1,3 & 2,4 & 1,1 & 0,5 & 1,3 & 1,2 & 0,6 \\
\hline
\end{tabular}

Método de extração: P - resina; B - água quente; Cu, Fé, Mn, Zn - DTPA 

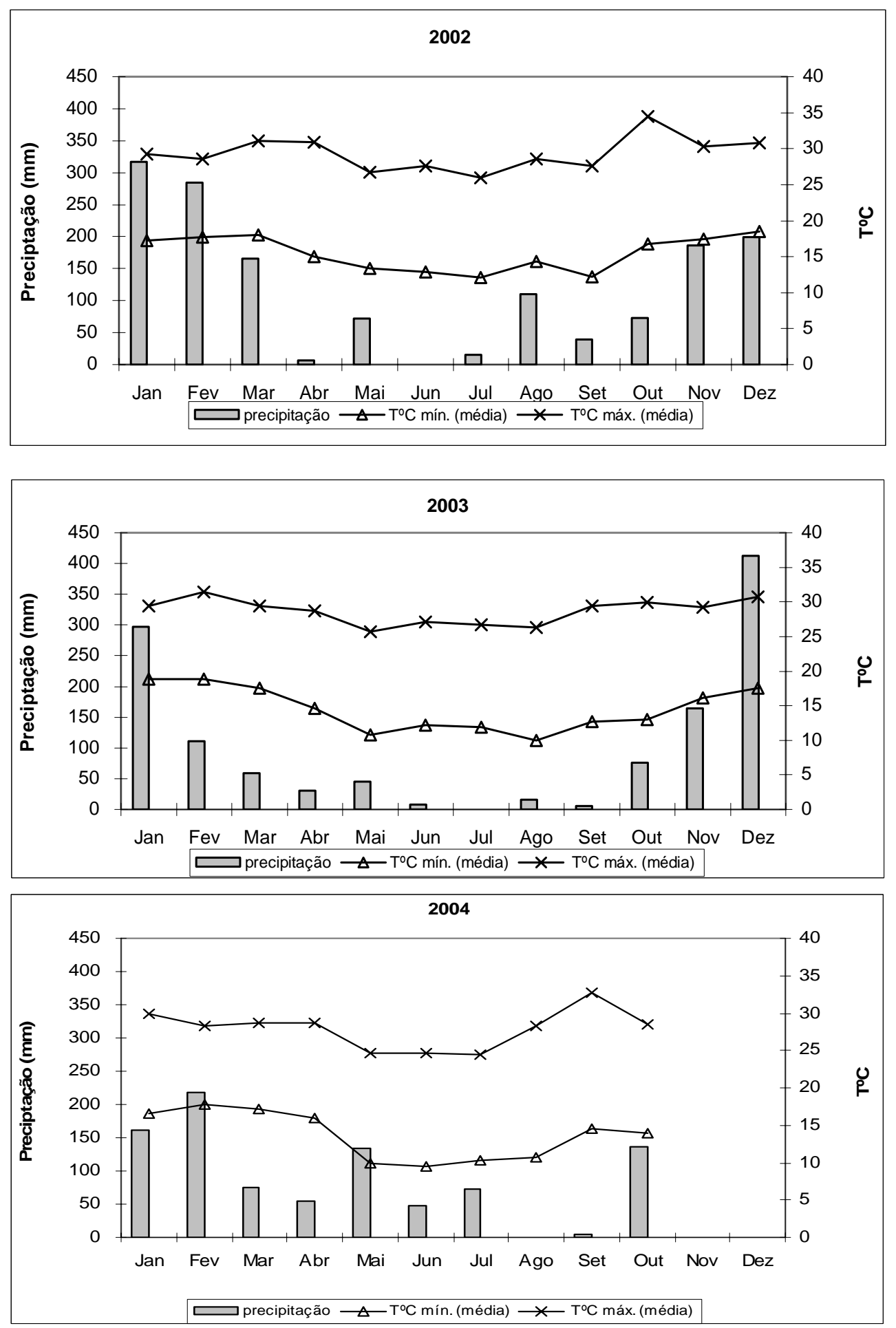

Figura 1 - Precipitação e médias das temperaturas máximas e mínimas durante o período do experimento. Fonte: Centro de Ciências Agrárias da Universidade Federal de São Carlos - CCA/UFSCAR, campus Araras, SP, distante 25 km em linha reta do local do experimento 
forma, o trabalho foi composto por apenas dois tratamentos, sendo um denominado Convencional e o outro Alternativo.

Para configurar as parcelas de avaliação, foram previamente selecionadas e identificadas 100 plantas para cada tratamento, considerando-se a semelhança do porte da copa (diâmetro e altura). Dentro dessas 10 conjuntos de 3 plantas contíguas foram escolhidas para cada tratamento, as quais foram denominadas como A, B e C. Os parâmetros de avaliação foram distribuídos entre as três plantas, de forma que a metodologia de amostragens de um não viesse interferir no resultado do outro (Figura 2).

As avaliações foram distribuídas da seguinte forma: Planta A: compactação de solo; Planta B: colonização micorrízica, esporos de FMA e nutriente foliar; e Planta C: densidade radicular superficial. Para a avaliação de quantidade e qualidade de frutos foram consideradas as três plantas da parcela, ou seja, A, B e C. 


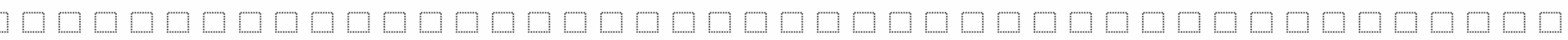
TRATAMEITO AL TERHATIVO

205 000000000000000000000000000000000000000000000

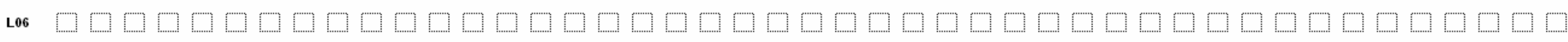

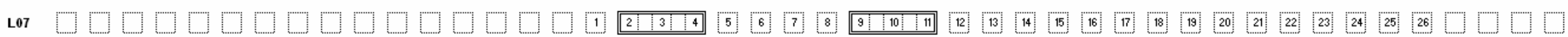

Lo3 D.

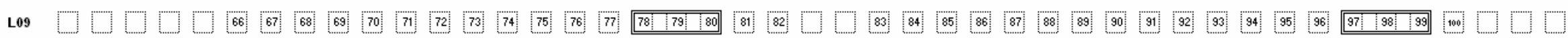

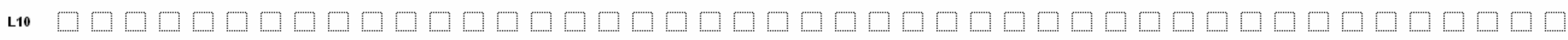

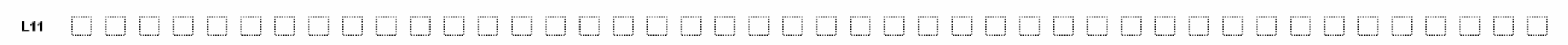

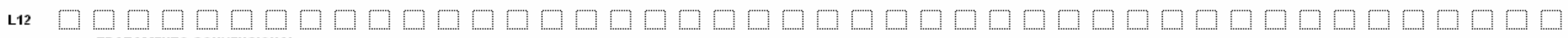

TRATAMEHTO COHVEHCIOHAL

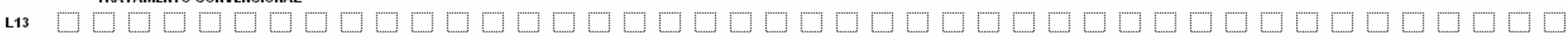

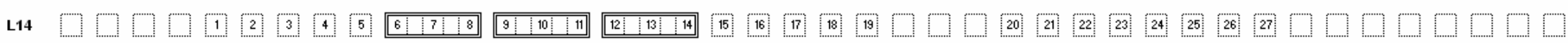

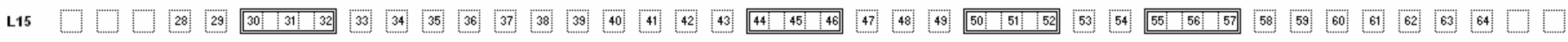

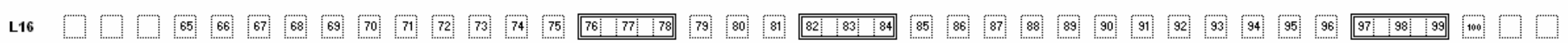

เ17 90000000000000000000000000000000000000000

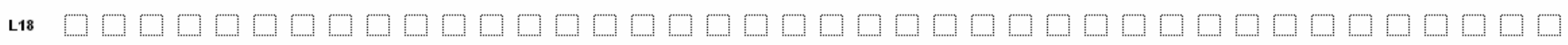

เ19 00000000000000000000000000000000000000

Legendas: $\quad[\square \Rightarrow$ Plantas de Tangor Murcott

[6] 66$]$ [6] $\Rightarrow$ Plantas identificadas e selecionadas para avaliaçổes

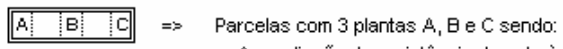

A: avaliaçẩo de resistência do solo à penetraçâå

B: avaliaçăo de colonizaçẫo micorrízica, esporos e conteúdo de nutriente foliar

C: volume radicular superficial
$A, B$ e C: avaliaçấo de quartidade e qualidade de frutos

Figura 2 - Croqui da área experimental e apresentação esquemática do delineamento e das parcelas de avaliação 


\subsection{Tratamentos}

\subsubsection{Tratamento Convencional}

O tratamento Convencional constituiu-se de todas as operações de fertilização, cuidados fitossanitários e práticas culturais aplicadas usualmente no talhão pelo proprietário.

Os insumos utilizados no tratamento Convencional foram:

- Corretivos: calcário dolomítico

- Fertilizantes via solo: Uréia, $\mathrm{KCl}, \mathrm{KNO}$, ácido bórico.

- Fertilizantes foliares: Brexil Top, Citrolino, Citrus Foliar, Nutril 00-30-20, Nutril Citrus, Profol, MnSO4, ZnSO4.

- Acaricidas: Abamectin 18g/l, Enxofre.

- Fungicidas: Propineb, Pyraclostrobin, Carbendazim, Mancozeb, Oxicloreto de Cobre, CuSO4, cal.

- Inseticidas: Acefato, Thiamethoxam, Deltametrina, Ethion, Dimetoato, Methidathion.

- Herbicidas: Glifosate.

- Espalhantes: Óleo mineral.

A vegetação espontânea foi controlada com aplicações de herbicidas na linha e roçadeira mecânica na entrelinha. As quantidades e a cronologia de aplicação dos insumos e tratos culturais ocorreram como apresentadas nos quadros 1, 2 e 3 no Anexo.

\subsubsection{Tratamento Alternativo}

No tratamento Alternativo, a partir do início do experimento, foram suspensas as aplicações de defensivos agrícolas sintéticos, fertilizantes químicos de alta solubilidade e os herbicidas, sendo substituídos por insumos Alternativos.

Os insumos utilizados no tratamento Alternativo foram:

- Corretivos: calcário dolomítico, Sulfato duplo de potássio e magnésio (Sulpomag: $\mathrm{K}_{2} \mathrm{O}: 22 \%$; Mg: 11\% e S: 22\%), Sulfato de Potássio, Termofosfato. 
- Nutri Bokashi: composto orgânico confeccionado a partir da fermentação láctica de uma mistura de farelos e tortas (arroz, trigo, mamona, etc.), fabricado e distribuído pela Korin Agropecuária Ltda, Ipeúna, SP. Sua finalidade é direcionar o processo de fermentação da matéria orgânica no solo, além de fornecer nutrientes. Em citros, a recomendação do fabricante é $800 \mathrm{~kg} \mathrm{ha}^{-1}$ aplicado em área total (linha e entrelinha) sobre a vegetação espontânea quando esta estiver em ponto de ser roçada. Os níveis médios de nutrientes são: $\mathrm{N}=3 \% ; \mathrm{P}=2 \%$; $\mathrm{K}=$ 1,4\%; Mn = 180 mg.kg ${ }^{-1} ; \mathrm{Zn}=110 \mathrm{mg} \cdot \mathrm{kg}^{-1} ; \mathrm{Fé}=900 \mathrm{mg} \cdot \mathrm{kg}^{-1} ; \mathrm{B}=20 \mathrm{mg} \cdot \mathrm{kg}^{-1}$; $\mathrm{Cu}=30 \mathrm{mg} \cdot \mathrm{kg}^{-1}$; M.O. $=60 \% ; \mathrm{pH}=6$; e umidade $12 \%$.

- Extrato aquoso de Bokashi: calda obtida do Garden Bokashi (insumo confeccionado de forma semelhante ao Nutri Bokashi) através de sua imersão em água, em diluições de $5 \mathrm{~kg}$ para cada 1.000 litros de água e pulverizado na copa. Sua finalidade é atuar como biofertilizante e reforçar a comunidade de microrganismos epifíticos do vegetal. As propriedades do produto são semelhantes ao do Nutri Bokashi.

- Fertilizante foliar: mistura de sais de macro e micronutrientes (Ca, K, Zn, Mn e $\mathrm{Cu}$ ) dissolvidos juntamente com cal hidratada, conhecido como calda viçosa.

- Calda Bordalesa: controle de pinta preta

- Calda Sulfocálcica: controle de ácaro da falsa ferrugem

- Enxofre: controle de ácaro da falsa ferrugem

A vegetação espontânea foi administrada através de roçadeira mecânica na entrelinha e roçada manualmente na linha. As quantidades e a cronologia de aplicação dos insumos e tratos culturais ocorreram como apresentadas nos quadros 1, 2 e 3 no Anexo.

As quantidades de insumos e operações de tratos culturais e fitossanitários foram dimensionadas de forma que os custos permaneceram semelhantes ao do tratamento Convencional. 


\subsection{Compactação do solo e sistema radicular}

\subsubsection{Resistência do solo à penetração}

A avaliação do estado de compactação do solo nos tratamentos foi feita através do método da análise da resistência à penetração. $\mathrm{O}$ equipamento utilizado foi 0 Modelo IAA/Planalsucar-Stolf dotado de um peso de curso constante para provocar a penetração da haste no solo através de impactos. Foram avaliadas 6 pontos das plantas A de cada uma das 10 parcelas dos tratamentos, eqüidistantes entre si em $70 \mathrm{~cm}$, partindo do eixo longitudinal da linha de plantio em direção ao centro da entrelinha em sentido Oeste, os quais foram denominados L1, L2 e L3, localizados dentro da faixa da linha de plantio, e E1, E2 e E3, os que se localizam na entrelinha (Figura 3).
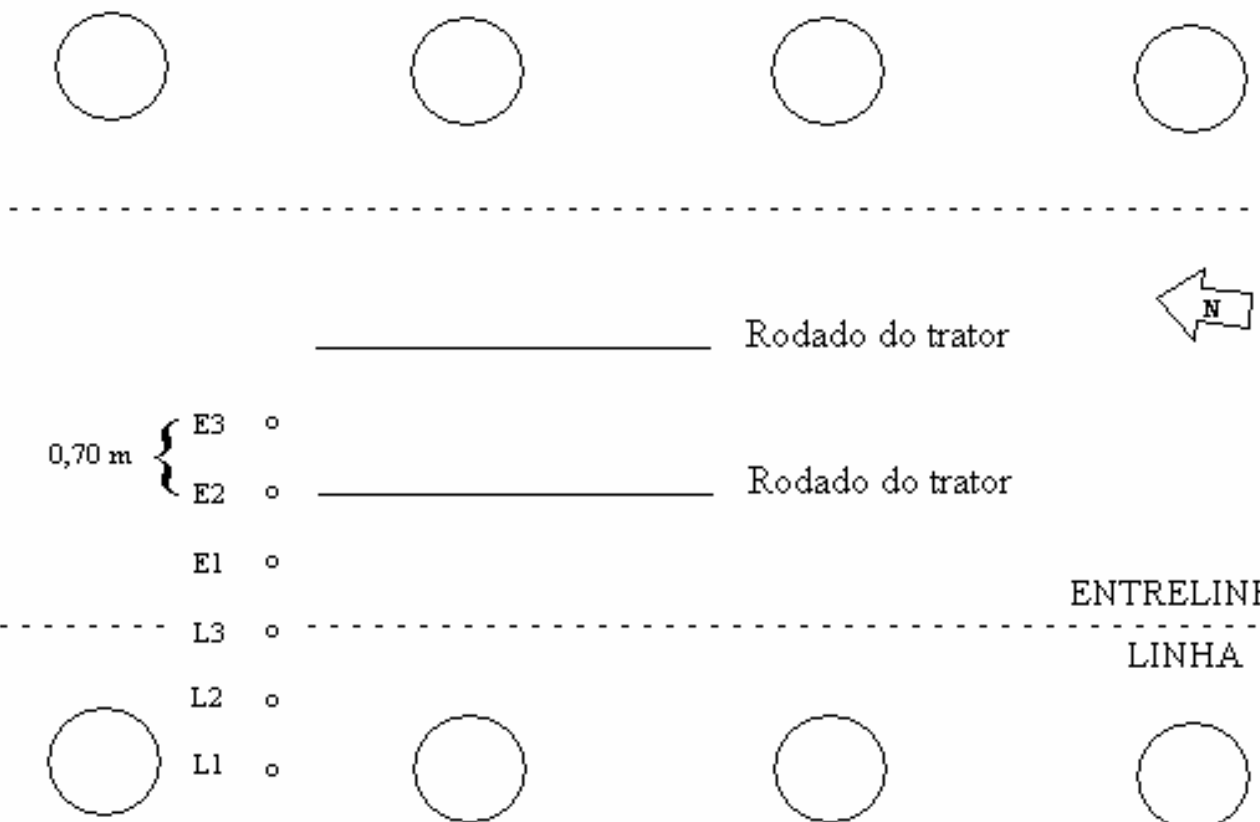

Rodado do trator
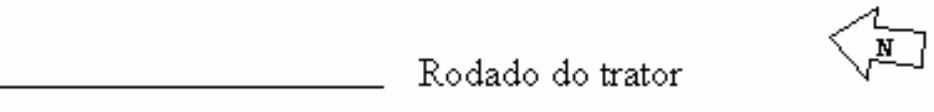

Rodado do trator

E1

ENTRELINHA

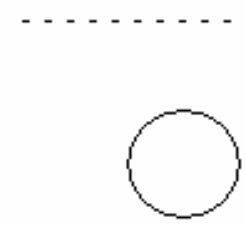

Flanta A

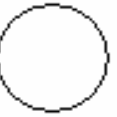

Flanta B
LINHA

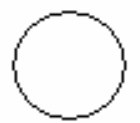

Planta C

Figura 3 - Esquema dos pontos de aferição da resistência do solo à penetração na parcela de avaliação

Com uma régua tipo alfaiate foi medida a profundidade penetrada pela haste do equipamento a cada 3 impactos, anotada em planilha e trabalhada no software 
Impact Penetrometer Stolf Model, versão 2.0. Os valores foram expressos em kgf.cm ${ }^{-2}$ para cada $5 \mathrm{~cm}$ de profundidade.

Concomitantemente à avaliação com penetrômetro, foram retiradas amostras de solo em 5 pontos determinados aleatoriamente em cada tratamento, em profundidades de 0 a 20, 20 a 40 e 40 a 60 cm, utilizando-se trado tipo 'holandês' e enviados ao laboratório para determinação da umidade.

Para obter os dados de resistência à penetração sempre em condições semelhantes entre as avaliações com o penetrômetro, foi escolhida a estação seca (agosto e setembro) para realizá-las.

\subsubsection{Densidade radicular superficial}

Para as avaliações da densidade radicular superficial das plantas das parcelas, optou-se pelo método do trado, descrito por Böhm (1979), avaliado por Köpke (1981).

Como as amostragem foram realizadas em profundidade única de $20 \mathrm{~cm}$, o método foi adaptado utilizando-se um coletor confeccionado a partir de um tubo metálico de 150 mm de diâmetro, tendo as bordas afiadas. Foram amostrados 4 pontos em volta das plantas C, de cada uma das 10 parcelas de avaliação de cada tratamento, nas direções norte, sul, leste e oeste, em distância de 1 metro a partir do tronco. O coletor foi cravado ao solo através de batidas de marreta na parte superior, retirado com cuidado e as amostras de solo contendo as raízes foram acondicionadas em sacos plásticos previamente identificados.

No laboratório as raízes foram separadas em jogo de peneiras de aço inox de malha 1 e $2 \mathrm{~mm}$, lavadas e pesadas. O peso de massa fresca foi expresso em gramas de raízes por $\mathrm{dm}^{3}$ de solo. Nas últimas avaliações, também foi obtido o peso seco das amostras, utilizando-se estufa a $110^{\circ} \mathrm{C}$ durante 24 horas.

Os períodos de avaliação foram os meses de abril e agosto de cada ano do experimento.

Objetivando obter uma visualização mais ampla da situação radicular, em janeiro de 2004 foi realizado um trabalho de remoção de aproximadamente $15 \mathrm{~cm}$ do 
solo superficial através de jatos de água na área do quadrante que corresponde a 2 metros partindo do tronco em direção a outra planta dentro da mesma linha e 2,5 metros partindo do mesmo tronco em direção ao centro da entrelinha. O teste foi realizado em 3 plantas, de porte semelhantes, de cada tratamento, escolhidas fora das parcelas de avaliação. As raízes foram tingidas com tinta branca sintética em aerossol e lavadas novamente para remover a tinta sobre o solo. A área do quadrante das plantas amostradas, que tiveram seu sistema radicular superficial descoberto, foi fotografada e as imagens digitalizadas foram trabalhadas no softaware MS COREL DRAW, versão 11.633, sendo as raízes tingidas com tons de amarelo, aplicando-se a ferramenta "pincel - ponta de feltro” tamanho 3. Posteriormente as imagens foram processadas no software

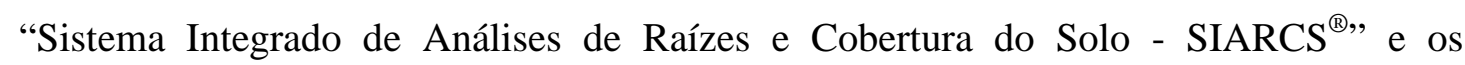
resultados expressos em área $\left(\mathrm{cm}^{2}\right)$ e comprimento de raízes (cm).

\subsection{Associação micorrízica}

\subsubsection{Colonização micorrízica radicular}

A amostragem para avaliação de colonização micorrízica foi realizada colhendo-se aproximadamente 10 gramas de raízes finas em 4 pontos das plantas B das parcelas de avaliação, entre 60 e 100 cm de distância do tronco a uma profundidade de 0 a $20 \mathrm{~cm}$, nas direções norte, sul, leste e oeste, que homogeneizadas formaram uma amostra composta.

No laboratório, as raízes foram lavadas, separadas e mantidas em solução de FAA (13 ml de formaldeído 40\%, $5 \mathrm{ml}$ de ácido acético glacial e $200 \mathrm{ml}$ de etanol 50\%). Aproximadamente $1 \mathrm{~g}$ de raiz das amostras foi acondicionado em tubo de ensaio para digestor, submerso com solução de $\mathrm{KOH} 10 \%$ e mantido à temperatura de $90^{\circ} \mathrm{C}$ constantes durante 1 hora no bloco digestor ${ }^{1}$. Esse processo remove o conteúdo citoplasmático clarificando o tecido cortical. Posteriormente, as raízes foram coloridas

\footnotetext{
${ }^{1}$ Método adaptado pelo Técnico Francisco Carlos Montrazi do Laboratório de Microbiologia do Centro de Energia Nuclear na Agricultura - CENA, USP, Piracicaba, SP, que substitui o banho maria pelo bloco digestor.
} 
com o corante Trypan blue $(0,05 \%)$ a $90^{\circ} \mathrm{C}$ por 30 minutos e conservadas em lactoglicerol claro até a contagem (Phillips \& Hayman, 1970).

A quantificação da colonização micorrízica foi realizada através do método do comprimento em lâmina (McGonigle et al., 1990). Foram utilizadas 4 lâminas por amostra, as quais continham 10 fragmentos de raízes com aproximadamente $1,2 \mathrm{~cm}$ dispostos paralelamente e delicadamente amassados de forma a quebrar a camada suberificada e permitir a visualização do seu interior. Através de observação em microscópio óptico 100X, registrou-se em cada campo ocular ao longo do fragmento, no total de 10, a presença ou ausência dos micélios do fungo. Ao final da observação, o índice de colonização radicular foi calculado através das médias de percentuais dos campos com presença micorrízica expresso em porcentagem de raízes infectadas.

\subsubsection{Quantidade de esporos no solo}

Para a quantificação de esporos, as amostras de solo foram retiradas em quatro sub-amostras nos mesmos pontos onde foram coletadas as raízes para análise de colonização micorrízica (planta B), que compuseram a amostra final.

A extração dos esporos foi feita pela técnica do peneiramento por via úmida (Gerdemann \& Nicolson, 1963) onde uma amostra de 50 g de solo é colocada em um recipiente com $1.000 \mathrm{ml}$ de água, agitada e após uma breve decantação foi passada em peneiras com abertura de 0,710 e 0,053 mm, repetindo-se essa operação por 3 vezes. O material retido na peneira de $0,053 \mathrm{~mm}$ foi coletado com água e centrifugado a 3.500 rpm por 4 minutos. O sobrenadante foi cuidadosamente eliminado, acrescido de solução de sacarose $50 \%$ e centrifugado a $1.500 \mathrm{rpm}$ durante 3 minutos. O sobrenadante foi passado em peneira 0,044 mm, lavado em água corrente para eliminar a sacarose, acrescido água destilada e mantido sob refrigeração. A quantificação procedeu-se em placa canelada e lupa 40X. Os resultados foram expressos em números de esporos viáveis para cada 50 gramas de solo.

As avaliações de colonização micorrízica e quantidade de esporos foram realizadas nos meses de abril e agosto de cada ano do experimento. 


\subsection{Conteúdo de nutrientes foliares}

As amostras para análise de conteúdo de nutrientes foliares também foram coletadas das plantas B das parcelas de avaliação colhendo-se 3 folhas de cada quadrante da árvore, nas direções Norte, Sul, Leste e Oeste, em altura mediana na terceira folha a partir do fruto (Quaggio et al., 1997). As amostras foram acondicionadas em sacos de papel, fechadas e enviadas ao Laboratório de Análises de Plantas do Departamento de Solos e Nutrição de Plantas da ESALQ-USP para análises.

As amostragens para análises de conteúdo de nutrientes foliares foram realizadas nos meses de abril e setembro de cada ano do experimento. As interpretações foram feitas utilizando-se as recomendações do Grupo Paulista de Adubação e Calagem para Citros - GPACC (1994).

\subsection{Produção e qualidade de frutos}

\subsubsection{Produção de frutos}

As frutas das parcelas de avaliação dos tratamentos foram colhidas, contadas e pesadas e os dados expressos em quilogramas e número de frutos por planta.

\subsubsection{Teores de sólidos solúveis ( ${ }^{\circ}$ brix) e acidez total}

A amostragem foi realizada colhendo-se no total 20 frutos aleatoriamente das 3 plantas que compõem as parcelas de avaliação de ambos os tratamentos. Os frutos amostrados foram armazenados em sacos plásticos, etiquetados e levados ao laboratório.

Os teores de sólidos solúveis foram determinados pelo método da leitura refratométrica e os valores expressos em graus Brix. A acidez total foi avaliada pelo método acidimétrico e os valores expressos em gramas de ácido cítrico por $100 \mathrm{ml}$ de suco (Carvalho et al., 1990). 


\subsection{Outras avaliações}

\subsubsection{Fitomassa da entrelinha}

A avaliação da fitomassa ocorrente na entrelinha da área experimental foi aplicada apenas no final do experimento, em janeiro de 2005, quando a maioria das espécies se encontrava em ponto máximo de vegetação. Foi utilizado o método do quadrado inventário ou censo da população vegetal (Braun-Blanquet, 1983), que consiste na utilização de um quadrado, com área interna conhecida, arremessado ao acaso na área a ser avaliada. Neste trabalho foi utilizado um quadrado confeccionado com arame grosso, com medidas internas de 0,55 x 0,55 m, totalizando 0,3 $\mathrm{m}^{2}$, arremessado ao acaso na entrelinha.

Foram aplicadas 10 repetições para cada tratamento, coletando-se toda a parte aérea da vegetação existente dentro do quadrado, separando-se por gêneros e armazenados em sacos plásticos distintos e identificados. O material foi levado ao laboratório, onde foi feita a identificação das espécies utilizando-se a publicação “Plantas Daninhas do Brasil: terrestres, aquáticas, parasitas e tóxicas” de Lorenzi (2000). As espécies foram pesadas separadamente obtendo-se a massa fresca.

\subsection{2 Ácaro da Falsa Ferrugem}

Os dados foram obtidos pelo monitoramento realizado na propriedade através do Manejo Integrado de Pragas - MIP, executado por “pragueiro” treinado, entre novembro de 2002 a setembro de 2004. Os procedimentos foram conforme descreve Gravena (1984) e Thomazini (2001), sendo inspecionadas periodicamente quatro plantas para cada tratamento, amostrando-se três frutos verdes por planta, na periferia da copa, ou em três folhas, quando não havia frutos. A verificação foi feita com auxílio de uma lupa com aumento de 10X, procedendo-se o controle sempre que foram detectados, em média, 10\% dos frutos ou folhas com mais de 20 ácaros. $\mathrm{cm}^{-2}$.

\subsubsection{Ortézia}

Os dados também foram obtidos pelo monitoramento realizado na propriedade, através do Manejo Integrado de Pragas - MIP, executado por “pragueiro” 
treinado, entre os anos de 2002 à 2004. Os procedimentos foram conforme descreve Gravena (1999) e Thomazini (2001), sendo o pomar periodicamente inspecionado e as plantas que apresentaram sintomas nas folhas e frutos, foram marcadas com uma fita de plástico, bem como a primeira planta da respectiva fileira, próximo ao carreador, que também foi marcada para facilitar a sua localização. O controle químico foi realizado diretamente nas plantas marcadas e nas plantas ao redor.

\subsection{Estatística}

As médias dos dados foram comparadas pelo Teste $t$ de Student, em níveis de 5\% de probabilidade $(\mathrm{P}<0,05)$ conforme Pimentel Gomes (1985). A quantidade de repetições recomendada para esse modelo é no mínimo 30. Entretanto, como as metodologias das avaliações são bastante trabalhosas, além de custosas, e considerando que para experimentos dessa natureza um parâmetro único pode não expressar os resultados de forma conclusiva, o número de repetições foi limitado a 10. 


\section{RESULTADOS E DISCUSSÃO}

\subsection{Compactação do solo e sistema radicular}

\subsubsection{Resistência do solo à penetração}

As avaliações de resistência do solo à penetração foram acompanhadas, concomitantemente, de análises do seu estado de umidade, conforme recomendado por Camargo \& Alleoni (1997). Os resultados não apresentaram diferenças estatísticas entre os tratamentos, dentro do mesmo período de avaliação e das mesmas faixas de profundidades amostradas de 0 a 20, 20 a 40 e 40 a $60 \mathrm{~cm}$ (Tabela 2). Portanto, pode-se afirmar que os resultados obtidos entre os tratamentos dentro do mesmo período são válidos. No entanto, como houve variação da umidade do solo entre os períodos de avaliação 2002, 2003 e 2004, não foi possível a formação de coeficientes lógicos que determinassem a evolução do parâmetro avaliado nos tratamentos em escala temporal.

Entretanto, considerando o fato das condições de textura e umidade do solo serem equivalentes para os tratamentos e que os tratos culturais do tratamento Convencional foram mantidos, portanto, não sofrendo nenhuma alteração em relação à fase anterior ao início do experimento, é possível correlacionar os valores obtidos no tratamento Alternativo com o Convencional, uma vez que o último foi constante. 
Tabela 2. Teores de umidade do solo (\%) em 3 profundidades, nos dois tratamentos, Convencional e Alternativo, na faixa de plantio (linha) e na faixa de trânsito (entrelinha), no período de 2002 a 2004, coletadas concomitantemente à avaliação de resistência do solo à penetração

\begin{tabular}{|c|c|c|c|c|c|c|c|}
\hline \multirow{3}{*}{ Local } & \multirow{3}{*}{$\begin{array}{c}\text { Profundidade } \\
0-20 \mathrm{~cm}\end{array}$} & \multicolumn{2}{|c|}{ Agosto 2002} & \multicolumn{2}{|c|}{ Agosto 2003} & \multicolumn{2}{|c|}{ Agosto 2004} \\
\hline & & \multicolumn{6}{|c|}{ Umidade do solo (\%) } \\
\hline & & $8,9 a$ & $7,8 \mathrm{a}$ & $8,2 \mathrm{a}$ & $8,1 \mathrm{a}$ & $10,8 a$ & $10,4 a$ \\
\hline \multirow[t]{2}{*}{ LINHA } & $20-40 \mathrm{~cm}$ & $10,1 \mathrm{a}$ & $9,8 \mathrm{a}$ & $9,1 \mathrm{a}$ & $9,8 a$ & $11,7 \mathrm{a}$ & $11,7 \mathrm{a}$ \\
\hline & $40-60 \mathrm{~cm}$ & $10,9 a$ & $10,8 \mathrm{a}$ & $9,5 a$ & $9,9 a$ & $12,5 \mathrm{a}$ & $12,6 \mathrm{a}$ \\
\hline ENTRE- & $0-20 \mathrm{~cm}$ & $8,1 \mathrm{a}$ & $8,2 \mathrm{a}$ & $9,0 \mathrm{a}$ & $8,1 \mathrm{a}$ & $9,8 \mathrm{a}$ & $10,2 \mathrm{a}$ \\
\hline \multirow[t]{2}{*}{ LINHA } & $20-40 \mathrm{~cm}$ & $9,7 a$ & $10,3 a$ & $9,2 \mathrm{a}$ & $9,1 \mathrm{a}$ & $12,0 \mathrm{a}$ & $12,4 \mathrm{a}$ \\
\hline & $40-60 \mathrm{~cm}$ & $10,8 \mathrm{a}$ & $11,3 \mathrm{a}$ & $9,8 \mathrm{a}$ & $9,8 \mathrm{a}$ & $12,5 \mathrm{a}$ & $13,6 \mathrm{a}$ \\
\hline
\end{tabular}

Letras diferentes na linha, dentro de cada época de amostragem, indicam significância pelo teste t em nível de $5 \%$ de probabilidade.

Médias de 5 repetições.

A avaliação do estado de compactação do solo realizada em agosto de 2002, na linha (L1, L2 e L3) e na entrelinha (E1, E2 e E3) dos tratamentos, demonstraram que a área do tratamento Convencional apresentava menor resistência do solo à penetração, em relação ao tratamento Alternativo, ocorrendo diferença estatística nas posições L1, L2, L3, E1 e E3. Esses resultados indicam que a área do tratamento Alternativo se encontrava em piores condições de compactação do solo, em relação ao Convencional, no início do experimento (Figura 4 e 5).

Em agosto de 2003 nas posições de avaliação L1 e L3 observou-se a equiparação do estado de compactação entre os tratamentos, desfazendo-se as diferenças estatísticas registradas na avaliação anterior. Esses resultados mantiveram-se até agosto de 2004. Já na posição L2, a equiparação somente ocorreu em agosto de 2004.

Esses resultados não permitem quantificar numericamente a melhora do estado de compactação do tratamento Alternativo, mas mostram claramente que houve 
uma evolução positiva em relação ao tratamento Convencional ao longo do experimento (Figura 4).

Nas posições de avaliação E1 e E3, o tratamento Alternativo apresentou maior resistência à penetração do solo até a avaliação de agosto de 2003. Já em agosto de 2004, foi detectada também, a equiparação do estado de compactação do solo entre os tratamentos, não diferindo mais entre si, denotando evolução positiva no estado físico do solo na entrelinha do tratamento Alternativo em relação ao Convencional.

A posição de avaliação E2 apresentou os maiores valores de resistência à penetração, quando comparado às outras posições na mesma avaliação, em todos os períodos. Esse fato se deve à coincidência da posição com a faixa de maior incidência do rodado de máquinas e implementos, coincidindo com a observação de Lima et al. (2004). Também, nessa posição os tratamentos não apresentaram diferenças estatisticamente válidas $(\mathrm{P}<0,05)$ em nenhum dos períodos avaliados ao longo do experimento (Figura 5).

A melhoria do estado de compactação na linha e entrelinha do tratamento Alternativo deste experimento se assemelha aos resultados observados por Rizzo (2000), que mostrou a capacidade das braquiárias em recuperar a estrutura do solo, através do crescimento do sistema radicular fasciculado nas fissuras naturais produzidas pela desidratação do perfil e que progressivamente geram os bioporos. De acordo com Cardoso \& Freitas (1992) e Tisdall (1994), o sistema radicular das gramíneas associadas com os FMAs, formam uma extensa malha de raízes e hifas entrelaçadas, cobertas por polissacarídeos extracelulares, as quais prendem os microagregados, e mantém os macroagregados intactos sem que sofram colapso com a presença de água, mantendo assim o solo descompactado. 
Linha 1

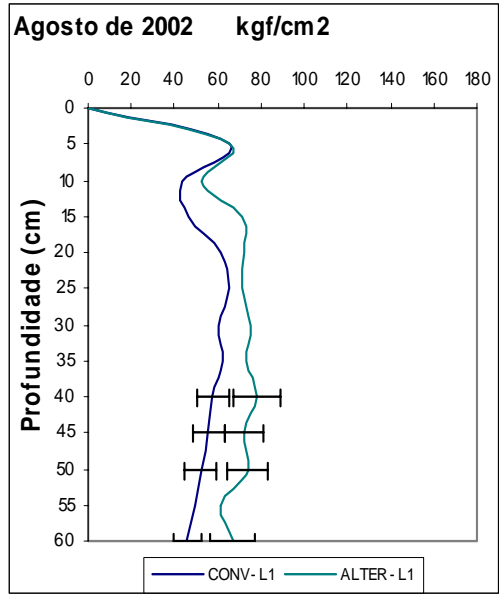

Agosto de $2003 \quad \mathrm{kgf} / \mathrm{cm} 2$

$\begin{array}{llllllllll}0 & 20 & 40 & 60 & 80 & 100 & 120 & 140 & 160 & 180\end{array}$

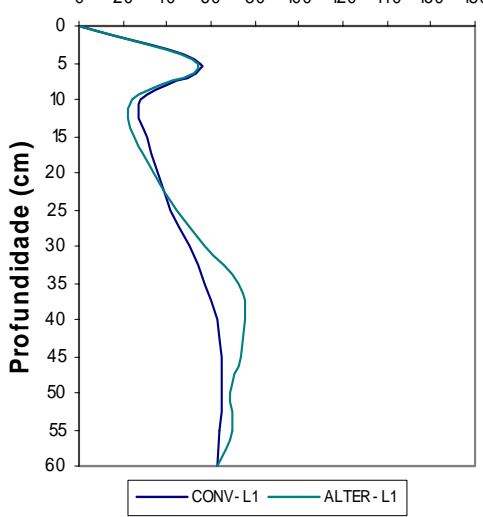

Agosto de $2004 \quad \mathrm{kgf} / \mathrm{cm} 2$

$\begin{array}{llllllllll}0 & 20 & 40 & 60 & 80 & 100 & 120 & 140 & 160 & 180\end{array}$

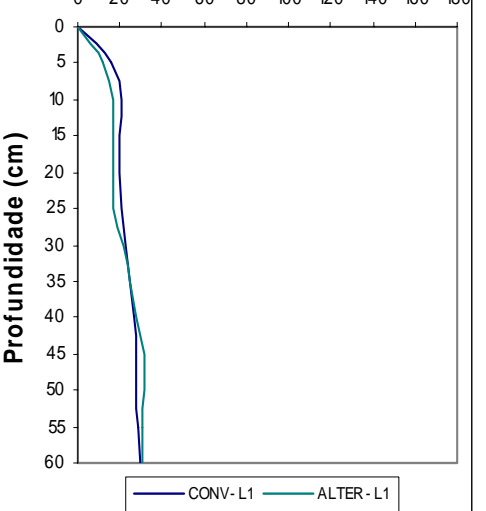

Linha 2
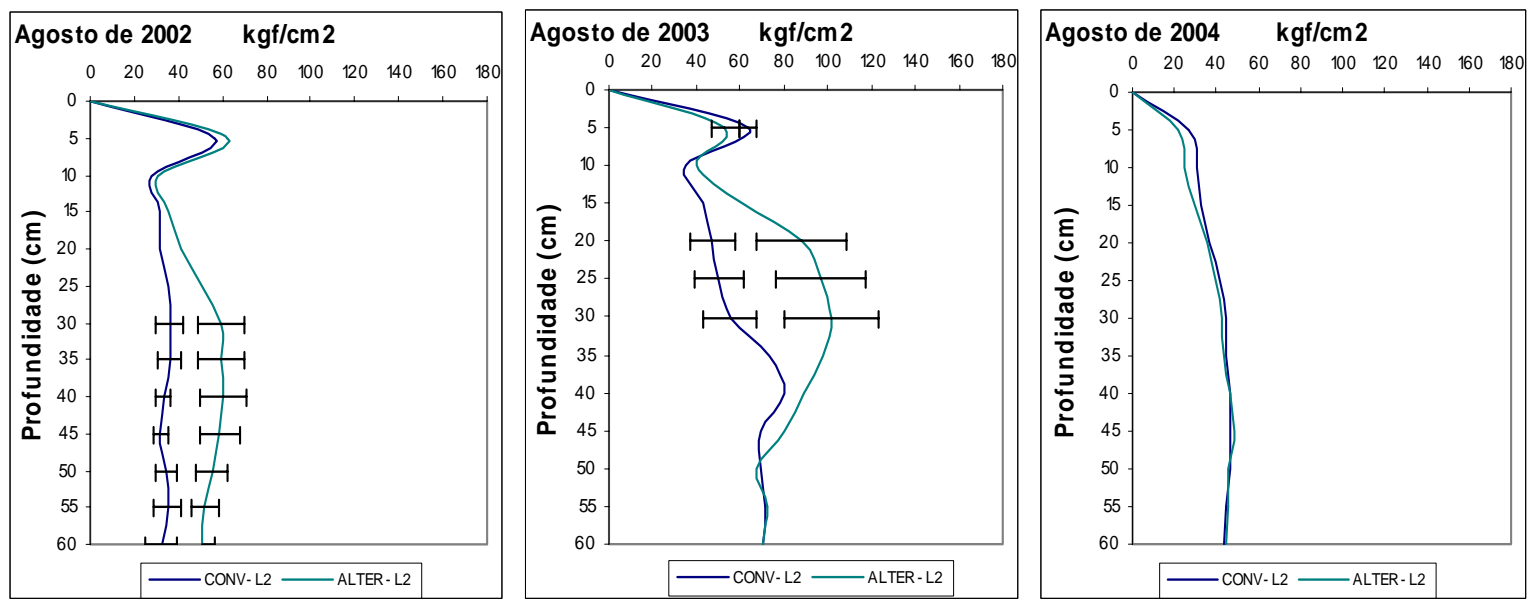

Linha 3
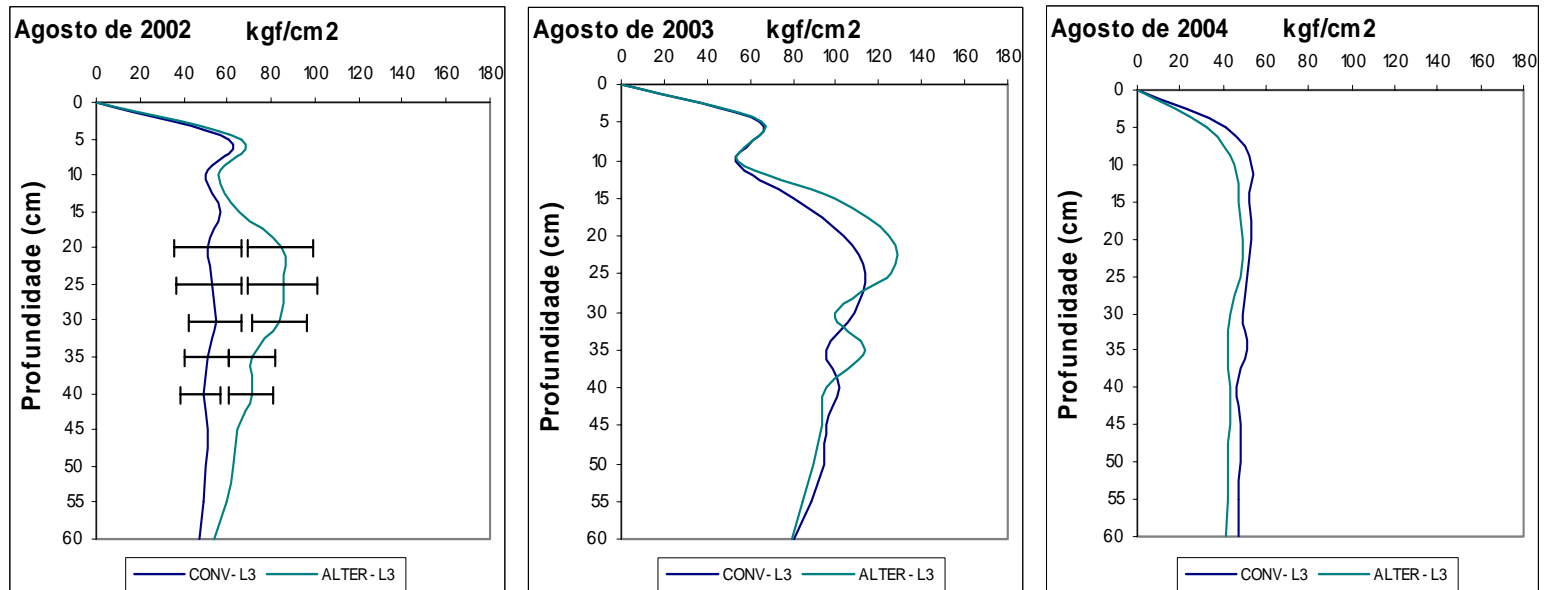

Figura 4 - Resistência do solo à penetração em $\left(\mathrm{kgf}_{\mathrm{cm}} \mathrm{cm}^{-2}\right)$ em 3 pontos da faixa da linha de plantio (L1, L2 e L3 = 0, 70 e $140 \mathrm{~cm}$ a partir do eixo da linha em direção a entrelinha) em dois tratamentos, Convencional e Alternativo, em pomar de tangor 'Murcott'no período de 2002 a 2004. As barras de erro padrão nas curvas dos gráficos indicam significância estatística a $5 \%$ pelo teste $\mathrm{T}$ para as respectivas profundidades. Médias de 10 repetições 


\section{Entrelinha 1}

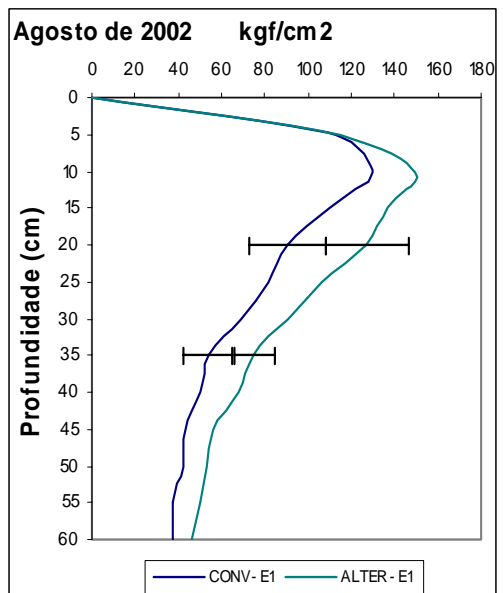

\section{Entrelinha 2}

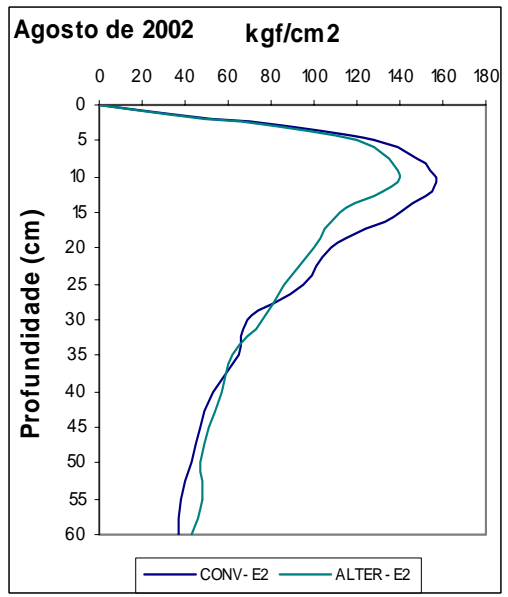

\section{Entrelinha 3}

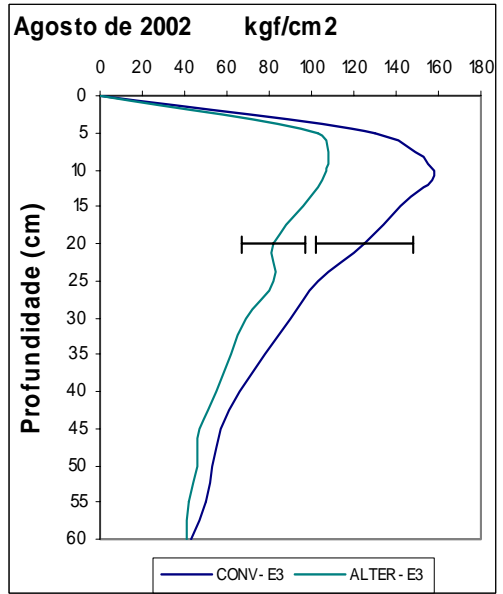

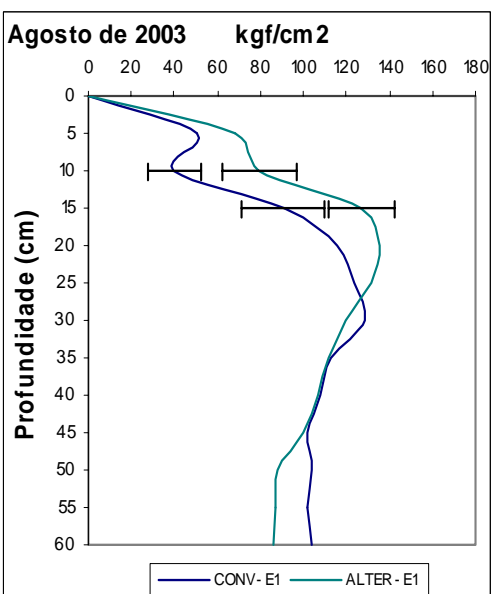

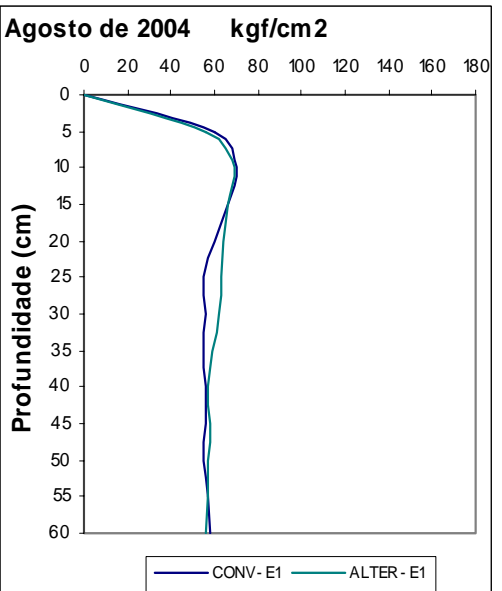

Agosto de $2003 \mathrm{kgf} / \mathrm{cm} 2$

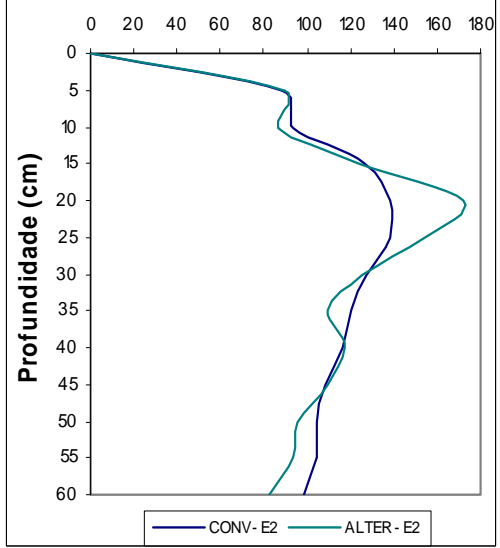

\section{Agosto de $2004 \quad \mathrm{kgf} / \mathrm{cm} 2$}

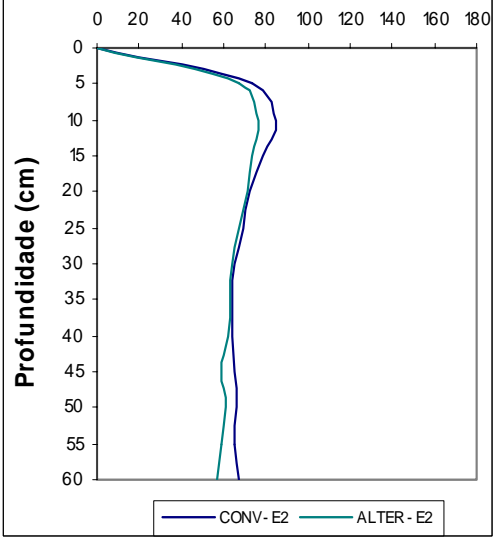

Figura 5 - Resistência do solo à penetração $\left(\mathrm{kgf}_{\mathrm{c}} \mathrm{cm}^{-2}\right)$ em 3 pontos da faixa da entrelinha (E1, E2 e E3 = 210, 280 e $350 \mathrm{~cm}$ a partir do eixo da linha em direção a entrelinha) em dois tratamentos, Convencional e Alternativo, em pomar de tangor 'Murcott'no período de 2002 a 2004. As barras de erro padrão nas curvas dos gráficos indicam significância estatística a 5\% pelo teste $\mathrm{T}$ para as respectivas profundidades. Médias de 10 repetições

Agosto de $2003 \mathrm{kgf} / \mathrm{cm} 2$

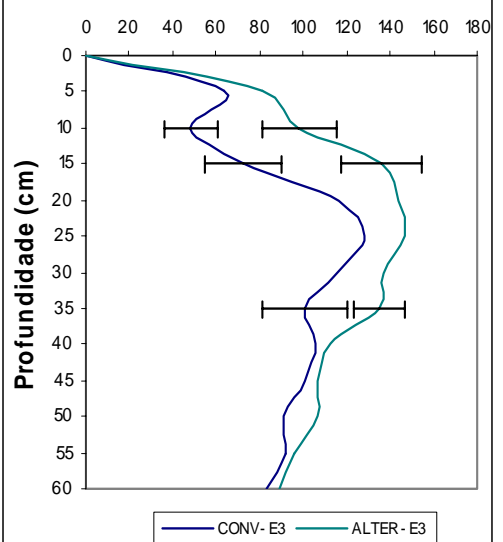

\section{Agosto de $2004 \mathrm{kgf} / \mathrm{cm} 2$}

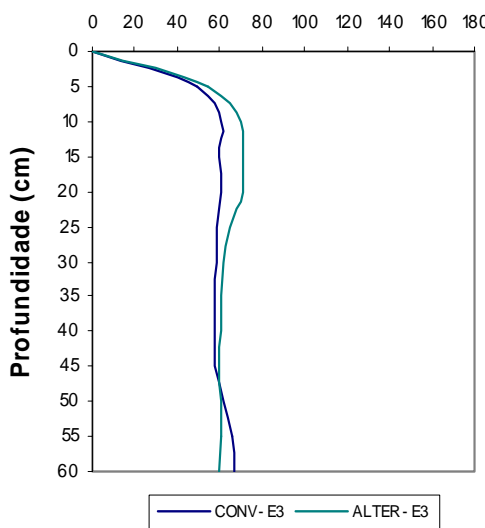




\subsubsection{Densidade radicular superficial}

Embora o método do trado tenha se mostrado eficaz para coletas de raízes em citros, a forma de distribuição dos pontos de amostragens adotada neste trabalho, 4 pontos distantes $1 \mathrm{~m}$ do tronco ao redor da árvore, não foi suficiente para avaliar o comportamento do sistema radicular superficial neste experimento. Moreira (1983) e Oliveira et al. (1998) obtiveram boa representação do comportamento do sistema radicular em citros, amostrando em diversos pontos eqüidistantes entre si, partindo do tronco em direção à planta vizinha, portanto, na linha de plantio, e no sentido transversal em direção ao centro da entrelinha.

As avaliações em 10 repetições não produziram resultados estatisticamente significativos nos parâmetros massa fresca (2002 a 2004) e massa seca (2004) de raízes por $\mathrm{dm}^{3}$ de solo, indicando que não houve diferenças na densidade de raízes nessa distância do tronco (Tabela 3 e 4).

Tabela 3. Massa fresca de raízes de tangor 'Murcott' em dois tratamentos, Convencional e Alternativo, coletadas em duas diferentes épocas do ano no período de 2002 a 2004

\begin{tabular}{lccc}
\hline Período & $\begin{array}{c}\text { Convencional } \\
\text { Massa fresca }\left(\mathbf{g . d m}^{-3}\right)\end{array}$ & $\mathbf{P}^{1}$ \\
\hline Agosto $2002^{2}$ & $1,40 \pm 0,21 \mathrm{a}$ & $1,51 \pm 0,21 \mathrm{a}$ & 0,7184 \\
${\text { Abril } 2003^{2}}^{\text {Agosto } 2003^{3}}$ & $1,11 \pm 0,23 \mathrm{a}$ & $1,60 \pm 0,34 \mathrm{a}$ & 0,2437 \\
${\text { Abril } 2004^{3}}^{\text {Agosto } 2004^{3}}$ & $0,41 \pm 0,11 \mathrm{a}$ & $0,46 \pm 0,12 \mathrm{a}$ & 0,7919 \\
\hline
\end{tabular}

Letras diferentes na linha, dentro de cada época de amostragem, indicam significância pelo teste t em nível de $5 \%$ de probabilidade.

${ }^{1}$ Probabilidade de que as diferenças sejam nulas pelo teste $t$.

${ }^{2}$ Foram computadas todas as raízes contidas nas amostras sem considerar suas espessuras.

${ }^{3}$ Foram consideradas apenas as raízes finas $(1 \mathrm{~mm})$.

Apresentação: média de 10 repetições \pm erro padrão. 
Tabela 4. Massa seca de raízes de tangor 'Murcott' em dois tratamentos, Convencional e Alternativo, coletadas em duas diferentes épocas do ano 2004

\begin{tabular}{|c|c|c|c|}
\hline \multirow[b]{2}{*}{ Período } & Convencional & Alternativo & \multirow{2}{*}{$\mathbf{P}^{1}$} \\
\hline & \multicolumn{2}{|c|}{ Massa seca $\left({\left.\mathrm{g} . \mathrm{dm}^{-3}\right)}^{-3}\right.$} & \\
\hline Abril $2004^{2}$ & $0,22 \pm 0,04 a$ & $0,22 \pm 0,03 a$ & 0,9150 \\
\hline Agosto $2004^{2}$ & $0,15 \pm 0,04 a$ & $0,13 \pm 0,03 a$ & 0,6681 \\
\hline $\begin{array}{l}\text { Letras diferentes } \\
\text { de } 5 \% \text { de probabi } \\
{ }^{1} \text { Probabilidade d } \\
{ }^{2} \text { Foram consider }\end{array}$ & $\begin{array}{l}\text { dentro de cada époc } \\
\text { iferenças sejam nul } \\
\text { as as raízes finas (1 }\end{array}$ & & \\
\hline
\end{tabular}

Segundo Moreira (1983) e Oliveira et al. (1998) a maior parte do sistema radicular de citros localiza-se em regiões bastante superficiais do solo. Assim, com o objetivo de obter uma visão mais ampla da situação das raízes, foi removido o solo superficial sobre o sistema radicular de 3 plantas de cada tratamento, utilizando-se jatos de água. Constatou-se que, visualmente, o volume de raízes superficiais no tratamento Alternativo era maior do que no tratamento Convencional (Figura 6).

As imagens processadas no software SIARCS são referentes a uma área sob as copas, sendo $2 \mathrm{~m}$ a partir do tronco na direção da linha e $1,5 \mathrm{~m}$ em direção a entrelinha. Os resultados demonstram que as plantas do tratamento Alternativo foram superiores tanto em área (56,1\% maior) como em comprimento de raízes (26,9\% maior), quando comparado com o tratamento Convencional (Tabela 5). Embora o número de repetições não permita uma apuração estatisticamente válida, os resultados indicam que o manejo Alternativo favoreceu o crescimento radicular superficial do tangor 'Murcott'. O efeito coincide com as recomendações de Mazza (2000) e Sanches (2000). Carvalho et al. (1999) observaram um incremento de até 146,8\% em laranja 'Pêra', sobre porta enxerto de limão 'Cravo', em condições de cobertura vegetal estimulada na entrelinha associada com subsolagem. 
CONVENCIONAL
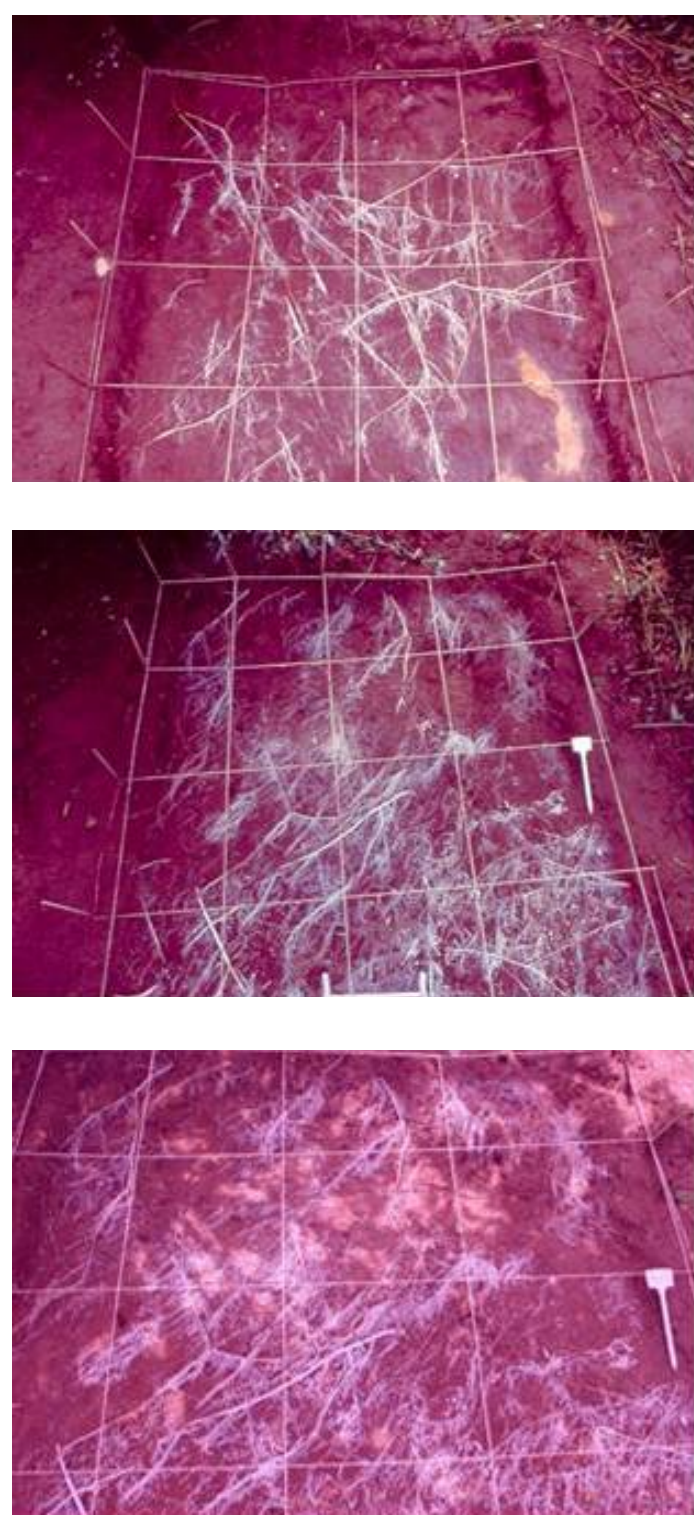

ALTERNATIVO
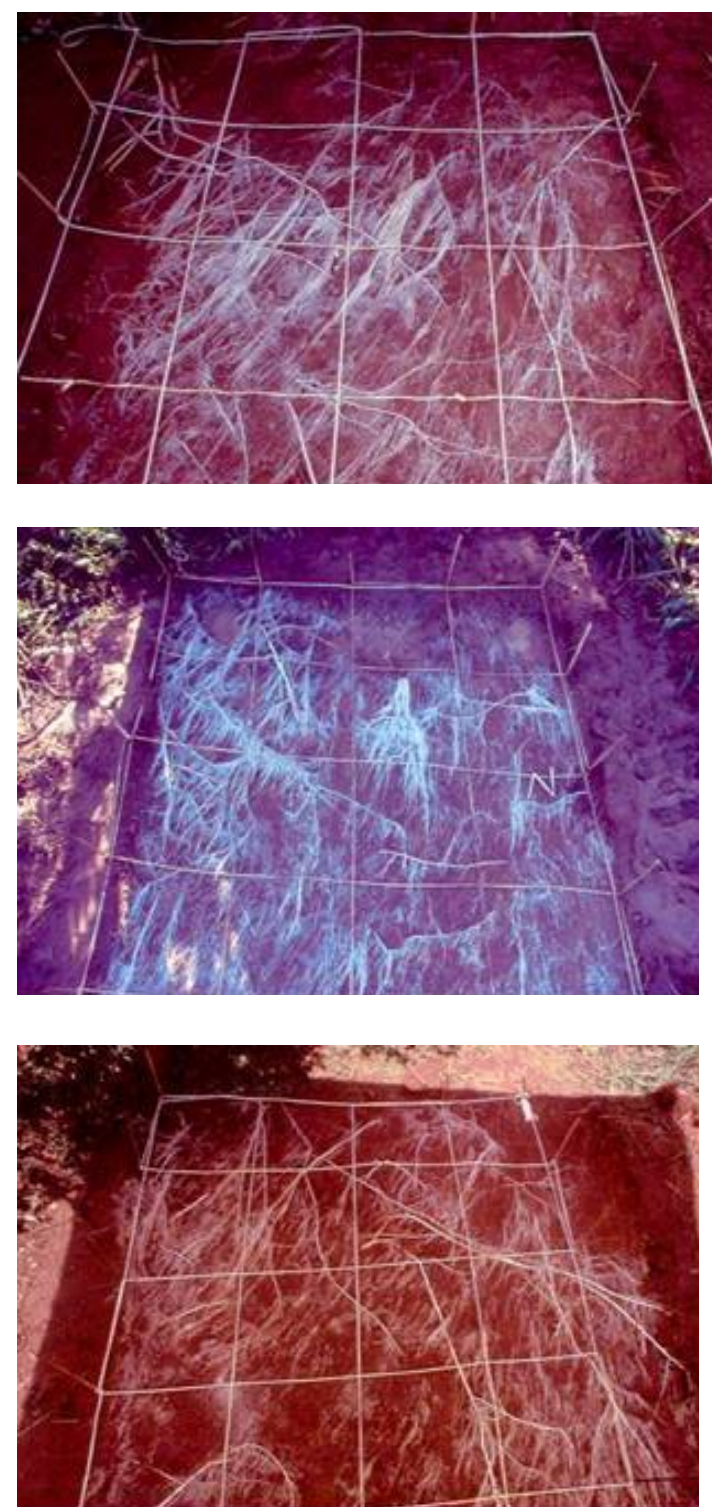

Figura 6 - Imagens de raízes de tangor Murcott de dois tratamentos, Convencional e Alternativo, após remoção do solo superficial com jatos de água e tingimento com tinta branca 
Tabela 5. Resultados em área $\left(\mathrm{cm}^{2}\right)$ e comprimento $(\mathrm{cm})$ de raízes superficiais obtidas pelo processamento de imagens digitalizadas no software SIARCS de três plantas de tangor 'Murcott', provenientes de dois tratamentos, Convencional e Alternativo, referente à área de $3 \mathrm{~m}^{2}$ sob a copa, $2 \mathrm{~m}$ a partir do tronco na direção da linha e $1,5 \mathrm{~m}$ em direção a entrelinha

\section{Convencional}

\section{Alternativo}

Área de raiz Comp. de raiz

Área de raiz Comp. de raiz $\mathbf{c m}^{2}$

$\mathbf{c m}$ $\mathbf{c m}^{2}$

cm

\begin{tabular}{ccccc}
\hline Planta 1 & $6.373,53$ & $8.496,86$ & $9.262,99$ & $13.383,56$ \\
Planta 2 & $6.200,51$ & $11.775,20$ & $6.703,63$ & $11.639,41$ \\
Planta 3 & $5.684,17$ & $9.284,76$ & $11.721,55$ & $12.497,06$ \\
Total & $18.258,21$ & $29.556,82$ & $27.688,17$ & $37.520,03$ \\
\hline
\end{tabular}

\subsection{Associação micorrízica}

\subsubsection{Colonização micorrízica radicular}

Na avaliação de agosto de 2002 não foram verificadas diferenças no índice de colonização de FMAs nativos nas raízes finas amostradas. Esse resultado, provavelmente, indica que os 6 meses que se passaram após o início do experimento não foram suficientes para provocar diferenças entre os índices de colonização. Já nas avaliações posteriores, foram verificadas diferenças nas amostragens de abril e agosto de 2003. Em abril e agosto de 2004, embora as diferenças não sejam estatisticamente válidas em nível de 5\%, as médias apuradas tenderam a ser maiores no tratamento Alternativo, quando comparado com o Convencional, com probabilidades baixas das diferenças serem nulas (21,12\% e 10,75\%) (Tabela 6). 
Tabela 6. Colonização de FMAs nativos em raízes finas de tangor 'Murcott' em dois tratamentos, Convencional e Alternativo, coletadas em duas diferentes épocas do ano no período de 2002 a 2004

\begin{tabular}{llcc}
\hline & \multicolumn{2}{c}{ Colonização de FMAs nativos (\%) } & \multirow{2}{*}{ P } \\
Período & Convencional & Alternativo & \\
\hline Agosto 2002 & $61,37 \pm 2,44 \mathrm{a}$ & $62,56 \pm 2,87 \mathrm{a}$ & 0,7553 \\
Abril 2003 & $68,58 \pm 1,45 \mathrm{~b}$ & $75,90 \pm 1,72 \mathrm{a}$ & 0,0044 \\
Agosto 2003 & $60,63 \pm 3,91 \mathrm{~b}$ & $73,69 \pm 2,49 \mathrm{a}$ & 0,0114 \\
Abril 2004 & $64,50 \pm 1,84 \mathrm{a}$ & $69,00 \pm 2,94 \mathrm{a}$ & 0,2112 \\
Agosto 2004 & $62,23 \pm 3,49 \mathrm{a}$ & $69,92 \pm 2,91 \mathrm{a}$ & 0,1075 \\
\hline
\end{tabular}

Letras diferentes na linha, dentro de cada época de amostragem, indicam significância pelo teste t em nível de $5 \%$ de probabilidade.

${ }^{1}$ Probabilidade de que as diferenças sejam nulas pelo teste $t$.

Apresentação: média de 10 repetições \pm erro padrão.

\subsubsection{Quantidade de esporos no solo}

Em relação à quantidade de esporos viáveis de FMAs nativos a cada $50 \mathrm{~g}$ de solo, a primeira avaliação, em agosto de 2002, não foi realizada por motivo de adequação de metodologia. Na avaliação de abril de 2003 não houve diferença significativa. Em agosto de 2003 e abril de 2004 os resultados foram estatisticamente favoráveis para o tratamento Alternativo. Em agosto de 2004, apesar de não diferir estatisticamente, a probabilidade de nulidade foi bastante baixa (14,4\%) (Tabela 7).

Os resultados da quantificação de esporos viáveis de FMAs nativos foram coerentes com os índices de colonização micorrízica apurados nas raízes finas das plantas dos tratamentos conforme se observa no gráfico da Figura 7.

A suspensão dos fertilizantes químicos e fungicidas e a substituição por insumos alternativos provavelmente favoreceram o aumento inicial do índice de colonização dos FMAs nativos e a quantidade de esporos no tratamento Alternativo. Miller \& Jackson (1998) observaram as perturbações produzidas pelas adubações pesadas sobre a colonização micorrízica e a abundância de esporos no solo. Trappe et al. (1984) e Kling \& Jakobsen (1997) relatam efeitos negativos sobre os FMAs, gerados por 
fungicidas com princípios ativos iguais aos utilizados no tratamento Convencional ao longo do experimento.

Tabela 7. Quantidade de esporos viáveis de FMAs nativos encontrados em $50 \mathrm{~g}$ de solo coletado sob a copa de plantas de tangor 'Murcott' em dois tratamentos, Convencional e Alternativo, em duas diferentes épocas nos anos de 2003 e 2004

\begin{tabular}{|c|c|c|c|}
\hline \multirow{2}{*}{ Período } & \multicolumn{2}{|c|}{$\mathrm{N}^{\mathrm{o}}$ de esporos/50 g de solo } & \multirow{2}{*}{$\mathbf{P}^{1}$} \\
\hline & Convencional & Alternativo & \\
\hline Agosto 2002 & N/D & N/D & N/D \\
\hline Abril 2003 & $206,5 \pm 10,3 a$ & $213,5 \pm 24,4 a$ & 0,7949 \\
\hline Agosto 2003 & $198,1 \pm 9,5 b$ & $244,1 \pm 14,3 a$ & 0,0153 \\
\hline Abril 2004 & $156,5 \pm 11,3 b$ & $200,0 \pm 15,8 a$ & 0,0377 \\
\hline Agosto 2004 & $184,5 \pm 14,5 a$ & $219,0 \pm 17,4 a$ & 0,1444 \\
\hline
\end{tabular}

Letras diferentes na linha, dentro de cada época de amostragem, indicam significância pelo teste t em nível de $5 \%$ de probabilidade.

${ }^{1}$ Probabilidade de que as diferenças sejam nulas pelo teste $\mathrm{t}$.

Apresentação: média de 10 repetições \pm erro padrão.

$\mathrm{N} / \mathrm{D}=$ não determinado

O maior volume de raízes de plantas hospedeiras, principalmente gramíneas, pode ter contribuído para a elevação de colonização por FMAs nativos no tangor 'Murcott'. Miller \& Jackson (1998) observaram correlação positiva entre a presença de mato e a colonização micorrízica na espécie cultivada e o número de esporos no solo. Boddington \& Dodd (2000), Eriksson (2001), Miller \& Jackson (1998) e Jordan et al. (2000) concluíram que os FMAs são favorecidos pelos manejos agrícolas que contemplam a constância do ambiente, presença de diversidade de plantas hospedeiras, cobertura morta e insumos de baixo impacto sobre o endófito. 


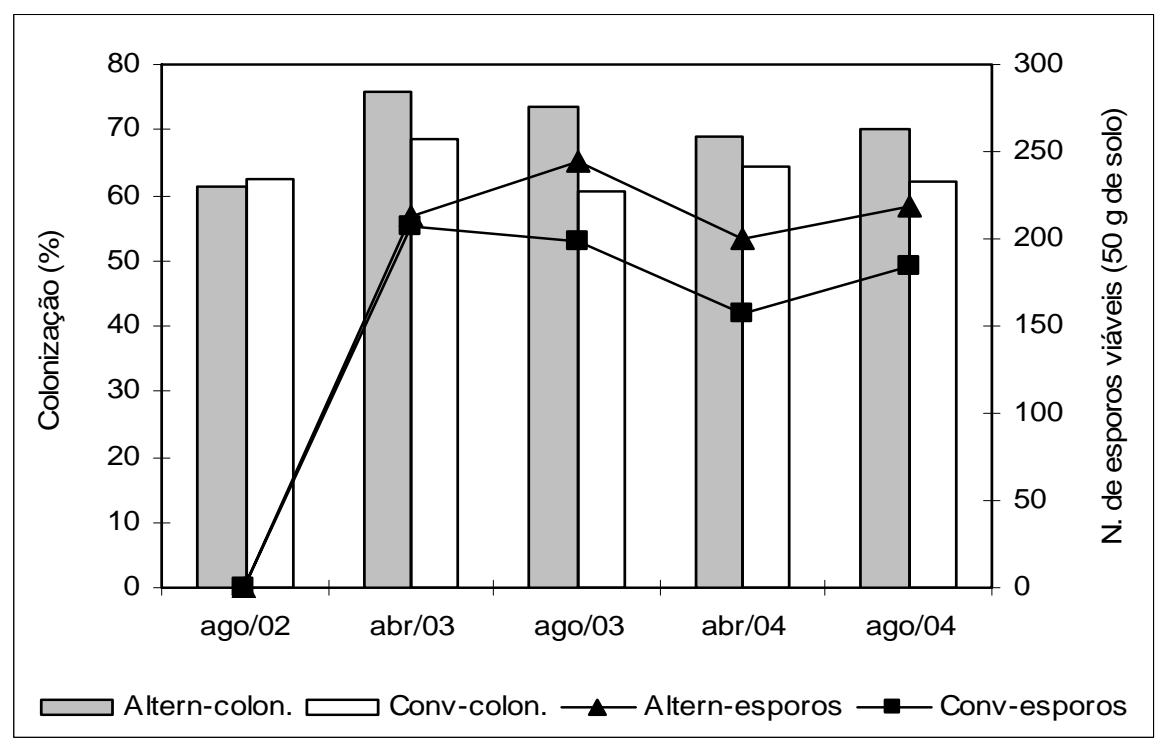

Figura 7 - Colonização de FMAs nativos em raízes finas e esporos viáveis encontrados em $50 \mathrm{~g}$ de solo em pomar de tangor 'Murcott' em dois tratamentos, Convencional e Alternativo, coletadas em duas diferentes épocas do ano no período de 2002 a 2004

\subsection{Conteúdo de nutrientes foliares}

Não foi possível avaliar com precisão o desempenho nutricional entre os dois tratamentos deste trabalho, uma vez que os insumos e os manejos aplicados foram bastante diferentes e as quantidades de nutrientes aportadas não foram comparadas. As análises apenas permitiram comparar os teores de nutrientes absorvidos nas folhas resultantes dos tratamentos.

Até a avaliação de abril de 2003 a maioria das médias dos teores de macro e micronutrientes contidos nas folhas foram maiores para o tratamento Convencional quando comparado com o tratamento Alternativo, sendo que, N, P, K e Cu foram superiores com significância estatística $(\mathrm{P}<0,05)$ em setembro de 2002 e, da mesma forma, o N, Cu, Mn e Zn em abril de 2003.

A partir da avaliação de setembro de 2003, os teores médios de nutrientes foliares do tratamento Alternativo começaram a superar os do tratamento Convencional. Na avaliação de setembro de 2003 é necessário ponderar que, a baixa produção do 
tratamento Alternativo daquele ano, pode ter permitido um maior residual nas folhas, devido a menor transferência para os frutos, principalmente de N, P e K. Em abril de 2004 os resultados foram bastante semelhantes à avaliação anterior e em setembro de 2004 a maioria dos elementos foram superiores ao tratamento Convencional, inclusive com diferenças estatísticas para $\mathrm{N}, \mathrm{Mg}, \mathrm{Cu}, \mathrm{Mn}$ e B. A exceção ficou para o K e Zn, que tiveram baixo desempenho durante quase todo o período experimental (Tabela 8).

Os teores médios de $\mathrm{K}$ foliar do tratamento Alternativo foram superiores ao do tratamento Convencional apenas na avaliação de setembro de 2003, muito provavelmente devido à baixa transferência do elemento para os frutos, resultante da quebra de produtividade de suas plantas apresentada no período. A aplicação de 1,2 kg de sulfato duplo de potássio granulado (22\% de $\mathrm{K}_{2} \mathrm{O}$ ) para cada planta em janeiro de 2004 não foi suficiente para abastecer a demanda durante a formação e maturação dos frutos, provavelmente por se tratar de fonte de liberação muita lenta. Isso indica que é preciso planejar melhor a suplementação de $\mathrm{K}$ através de fontes pouco solúveis nas propostas alternativas de manejo para citros.

Provavelmente, os baixos níveis de $\mathrm{K}$ foliar contribuíram para a maior sensibilidade das plantas do tratamento Alternativo ao período de estiagem registrado durante o ano de 2003, tendo agravado a baixa produtividade da respectiva safra. O K tem importante papel no controle da abertura dos estômatos, mecanismo que regula o regime hídrico nas plantas superiores, e no potencial osmótico dos vacúolos, que mantêm a umidade nos tecidos mesmo em condições de baixa umidade, conferindo aos vegetais maior tolerância à seca (Marschner, 1995).

A deficiência de K é a causa mais provável para os frutos não atingirem melhores desempenhos no quesito peso médio dos frutos neste experimento. Em citros, frutos pequenos podem estar associados com baixo nível de $\mathrm{K}$ nas folhas, segundo du Plessis (1992). Mattos Junior et al. (2004) constataram que o tangor 'Murcott' responde aumentando o tamanho dos frutos quando se aumenta a dose de $\mathrm{K}$.

$\mathrm{O}$ teor médio de $\mathrm{Zn}$ foliar no tratamento Alternativo foram significativamente inferiores ao tratamento Convencional em todas as avaliações, com exceção apenas de setembro de 2002, e os níveis permaneceram abaixo do limite 
adequado, conforme as recomendações do Grupo Paulista de Adubação e Calagem para Citros (1994), nas avaliações de setembro de 2002, abril de 2003 e setembro de 2004. O Zn é componente de uma larga quantidade de enzimas que atuam em diversos processos fisiológico nos vegetais, além de preservar a integridade de membranas, interagir na absorção de outros elementos e atuar na síntese de proteínas (Marschner, 1995). Dessa forma, é difícil estimar se houve e quais foram as interferências do Zn nos períodos em que houve deficiência. A absorção de Zn é mais eficiente em aplicações via foliar do que via solo, segundo Quaggio et al. (2003), portanto, pulverizações desse nutriente com mais intensidade poderiam contornar o problema.

Os teores médios de $\mathrm{P}$ foliar do tratamento Alternativo se manteve superior, em relação ao tratamento Convencional, em todas as avaliações a partir de abril de 2004, apesar dos níveis de ambos terem se apresentado um pouco abaixo dos limites adequados recomendado pelo Grupo Paulista de Adubação e Calagem para Citros (1994). Esse resultado pode ser conseqüência dos índices superiores de colonização de FMAs verificados no tratamento Alternativo associados à aplicação de termofosfato na faixa da entrelinha (31 g.m ${ }^{-2}$ em outubro de 2003 e 18 g.m ${ }^{-2}$ em fevereiro de 2004). Cardoso et al. (1986) e Melloni \& Cardoso (1996) observaram incremento no P acumulado na parte aérea relacionado com aumento da colonização micorrízica em porta enxertos cítricos sob doses adequadas de P no solo.

Os teores médios de $\mathrm{B}$ foliar no tratamento Alternativo despertam a atenção para o comportamento deste nutriente. Excetuando a amostragem de setembro de 2002, todas as avaliações posteriores apresentaram valores superiores, quando comparado com o tratamento Convencional, atingindo até $280 \%$ a mais de B foliar com teores de até 161,35 mg. $\mathrm{kg}^{-1}$. Também é igualmente interessante, a forma crescente como evoluíram os teores do B foliar ao longo deste experimento, no tratamento Alternativo, recuando apenas na última avaliação, mesmo porque, o nível do elemento já estava bastante elevado.

Não foram encontradas muitas referências que explicassem claramente esse comportamento do B nas plantas do tratamento Alternativo. A absorção de B está 
Tabela 8. Análise química foliar de tangor 'Murcott' em dois tratamentos, Convencional e Alternativo, coletadas em duas diferentes épocas do ano no período de 2002 a 2004

\begin{tabular}{|c|c|c|c|c|c|c|c|c|c|c|c|c|}
\hline & \multirow{2}{*}{ Unidade } & \multirow{2}{*}{$\begin{array}{c}\text { Limite } \\
\text { Adequado }\end{array}$} & \multicolumn{2}{|c|}{ Set 2002} & \multicolumn{2}{|c|}{ Abr 2003} & \multicolumn{2}{|c|}{ Set 2003} & \multicolumn{2}{|c|}{ Abr 2004} & \multicolumn{2}{|c|}{ Set 2004} \\
\hline & & & Conv. & Altern. & Conv. & Altern. & Conv. & Altern. & Conv. & Altern. & Conv. & Altern. \\
\hline $\mathbf{N}$ & g. $\mathrm{Kg}^{-1}$ & $23-27$ & $29,76 \mathrm{a}$ & $23,42 \mathrm{~b}$ & 28,67 a & $25,49 \mathrm{~b}$ & $22,53 \mathrm{~b}$ & $25,06 \mathrm{a}$ & 22,58 & 23,90 & $20,22 \mathrm{~b}$ & $22,78 \mathrm{a}$ \\
\hline $\mathbf{P}$ & g. $\mathrm{Kg}^{-1}$ & $1,2-1,6$ & $1,98 \mathrm{a}$ & $1,36 \mathrm{~b}$ & 1,09 & 1,21 & $0,93 \mathrm{~b}$ & $1,17 \mathrm{a}$ & 1,16 & 1,24 & 0,94 & 1,02 \\
\hline $\mathbf{K}$ & g. $\mathrm{Kg}^{-1}$ & $10-15$ & 14,85 a & $11,06 \mathrm{~b}$ & 9,34 & 9,57 & $7,27 \mathrm{~b}$ & $12,17 \mathrm{a}$ & 8,16 & 7,35 & 11,81 & 9,23 \\
\hline Ca & g. $\mathrm{Kg}^{-1}$ & $35-45$ & 17,34 b & 23,92 a & 31,82 & 30,16 & 38,45 & 34,14 & 43,44 a & 37,39 b & 36,72 & 38,60 \\
\hline Mg & g. $\mathrm{Kg}^{-1}$ & $2,5-4,0$ & 2,83 & 2,82 & 2,15 & 2,56 & 2,65 & 2,83 & 2,96 & 3,23 & $2,5 \mathrm{~b}$ & 3,39 a \\
\hline S & g. $\mathrm{Kg}^{-1}$ & $2,0-3,0$ & 2,12 & 2,16 & 2,33 & 2,24 & 2,95 & 3,07 & $3,13 b$ & 3,90 a & 2,16 & 2,18 \\
\hline $\mathrm{Cu}$ & $\mathrm{mg} \cdot \mathrm{Kg}^{-1}$ & $04-10$ & 16,50 a & $7,51 \mathrm{~b}$ & 30,86 a & $20,13 \mathrm{~b}$ & 11,73 a & $6,63 \mathrm{~b}$ & 83,14 & 71,87 & $21,31 \mathrm{~b}$ & $30,24 \mathrm{a}$ \\
\hline Fé & mg.Kg ${ }^{-1}$ & $50-120$ & 186,05 & 228,92 & 178,61 & 179,99 & 159,43 & 166,13 & 478,50 & 529,00 & 159,07 & 167,63 \\
\hline Mn & mg.Kg ${ }^{-1}$ & $35-50$ & 32,80 & 34,07 & 58,82 a & 33,94 b & $57,09 \mathrm{~b}$ & 99,04 a & 63,55 & 75,55 & $42,32 \mathrm{~b}$ & $52,32 \mathrm{a}$ \\
\hline Zn & mg.Kg ${ }^{-1}$ & $35-50$ & 32,55 & 25,86 & 35,77 a & 21,38 b & 81,62 a & 65,92 b & 93,12 a & 46,92 b & 61,41a & 33,36 b \\
\hline B & mg. $\mathrm{Kg}^{-1}$ & $36-100$ & 59,18 & 61,30 & $45,76 \mathrm{~b}$ & $96,18 \mathrm{a}$ & $36,47 \mathrm{~b}$ & 138,70 a & $44,60 \mathrm{~b}$ & $161,35 \mathrm{a}$ & $51,17 \mathrm{~b}$ & 140,57 \\
\hline
\end{tabular}

Método de extração: P=resina; B=água quente; $\mathrm{Cu}, \mathrm{Fe}$, Mn e Zn= DTPA.

${ }^{1}$ Conforme Grupo Paulista de Adubação e Calagem para Citros (GPACC).

Letras diferentes na linha, dentro de cada época de amostragem, indicam significância pelo teste t em nível de 5\% de probabilidade.

Apresentação: média de 10 repetições. 
relacionada a uma boa disponibilidade do nutriente no solo, fato não observado neste experimento para nenhum dos tratamentos.

A disponibilidade de B para as plantas depende das reações de adsorção, dessorção e lixiviação do elemento no solo, que por sua vez, são influenciadas pelo seu $\mathrm{pH}$, textura, umidade, temperatura e matéria orgânica, bem como o teor e a mineralogia das argilas (Goldberg, 1997). A adsorção é mais ocorrente em solos com maior teor de argila, óxido de ferro e de alumínio (Alleoni \& Camargo, 2000), como também em solos com C orgânico e pH mais elevados (Valladares et al., 1999). A matéria orgânica pode adsorver muito mais $\mathrm{B}$ do que os minerais componentes das argilas e tem papel bastante importante nos solos arenosos, onde o elemento é mais facilmente lixiviado (Yermiyahu et al., 2001). Maiores perdas de B pela lixiviação podem ocorrer em regiões quentes e de alta precipitação (Shorrocks, 1997).

Ainda há bastante contradição entre os resultados experimentais e as observações de campo, sugerindo que os fatores que determinam a absorção do B ainda são bastante desconhecidos (Hu \& Brown, 1997). De acordo com Goldberg (1997) o B é absorvido diretamente pela planta quando o elemento está disponível na solução do solo, no entanto, quando o mesmo estiver adsorvido nos constituintes de solo, a absorção somente é possível por meios indiretos. É possível que as condições biológicas mais intensas, geradas pelo tratamento Alternativo, tenham contribuído para o desempenho do B foliar. Martins et al. (2002) verificaram maior conteúdo de nitrogênio, cálcio e boro em pêssegos (Prunus persica L. Batsch) produzidos em pomares manejados com cobertura vegetal no manejo de solo do que no cultivo tradicional.

Para a citricultura, esse resultado com o B é bastante interessante e merece mais estudos, pois a deficiência do elemento está associada a uma infinidade de prejuízos à planta.

\subsection{Produção e qualidade dos frutos}

\subsubsection{Produção de frutos}

A idade avançada das plantas e os baixos preços nos últimos anos não estimularam a aplicação de todos os recursos possíveis, principalmente de fertilização, 
no pomar de tangor 'Murcott' da propriedade. Dessa maneira, os patamares de produtividade no pomar, em geral, foram abaixo das quantidades citadas por Figueiredo (1991).

Na primeira colheita do experimento, em agosto de 2002, as médias de peso e número de frutos por planta nas parcelas avaliadas foram de 54,6 kg e 320,4 frutos para o tratamento Convencional e 61,5 kg.planta ${ }^{-1}$ e 371 frutos para o tratamento Alternativo, não apresentando diferenças estatísticas entre si (Tabela 9). Provavelmente, a produção do tratamento Alternativo deste período ainda seja resultante dos tratos aplicados até o início do experimento, que ocorreu em fevereiro de 2002.

Em 2003 houve uma sensível queda na produção e na qualidade dos frutos nas parcelas do tratamento Alternativo, colhendo-se médias de 32,0 kg e 267,1 frutos contra 81,4 kg e 564,1 frutos por planta do tratamento Convencional, diferindo estatisticamente entre si. A suspensão brusca das fontes solúveis de nutrientes e a substituição por insumos alternativos não responderam positivamente na produtividade no primeiro momento, indicando que, na adoção de mudanças de manejo o processo deve ser gradativo.

Em 2004 as plantas do tratamento Alternativo recuperaram parcialmente a capacidade produtiva, inclusive apresentando médias de massa e quantidade de frutos por plantas superiores ao tratamento Convencional. As médias foram 42,9 kg e 367,0 frutos para as parcelas do tratamento Convencional e 58,6 kg e 589,6 frutos por planta no Alternativo. 
Tabela 9. Produção, quantidade e peso médio de frutos de tangor 'Murcott' em dois tratamentos, Convencional e Alternativo, no período de 2002 a 2004

\section{Convencional}

Alternativo

\begin{tabular}{ccccccc} 
Ano & kg.planta $^{-1}$ & frutos.planta $^{-1}$ & Kg.fruto $^{-1}$ & kg.planta $^{-1}$ & frutos.planta $^{-1}$ & kg.fruto $^{-1}$ \\
\hline 2002 & $54,6 \pm 4,8 \mathrm{a}$ & $320,4 \pm 30,5 \mathrm{a}$ & 0,172 & $61,5 \pm 5,8 \mathrm{a}$ & $371,0 \pm 38,5 \mathrm{a}$ & 0,202 \\
2003 & $81,4 \pm 8,7 \mathrm{a}$ & $564,4 \pm 61,4 \mathrm{a}$ & 0,144 & $32,0 \pm 5,4 \mathrm{~b}$ & $267,1 \pm 44,5 \mathrm{~b}$ & 0,120 \\
2004 & $42,9 \pm 5,9 \mathrm{~b}$ & $367,0 \pm 59,0 \mathrm{~b}$ & 0,117 & $58,6 \pm 4,4 \mathrm{a}$ & $589,6 \pm 50,7 \mathrm{a}$ & 0,099 \\
\hline
\end{tabular}

Letras diferentes na linha, dentro de cada época de amostragem, indicam significância pelo teste t em nível de $5 \%$ de probabilidade.

Apresentação: média de 30 repetições \pm erro padrão.

As repetidas operações de amostragens para determinação de densidade radicular superficial e colonização micorrízica ao longo do experimento causaram visível estado de estresse às plantas eleitas para avaliação e acabaram por prejudicar o desempenho de produção das parcelas, tanto no tratamento Convencional como no Alternativo. Para avaliar a intensidade do efeito do estresse provocado, foi selecionada uma parcela extra para cada tratamento, formada também por 3 plantas contíguas, com porte e aparência semelhantes entre si, cujas massas e os números de frutos foram determinados. As médias das parcelas extras foram superiores às médias das parcelas experimentais, demonstrando que houve efeito do estresse sobre a produtividade (Tabela 10).

Tabela 10. Avaliação da produção, quantidade e peso médio de frutos de 3 plantas de cada tratamento, Convencional e Alternativo, fora das parcelas de avaliação, com porte e aparência semelhante, escolhidas dentro da área experimental, comparada com as médias das parcelas experimentais no ano de 2004

\section{Convencional}

Alternativo

\begin{tabular}{lcccccc} 
Local & kg.planta & frutos.planta & kg.fruto $^{-1}$ & kg.planta $^{-1}$ & frutos.planta $^{-1}$ & kg.fruto $^{-1}$ \\
\hline $\begin{array}{l}\text { Parcela } \\
\text { Extra }^{1}\end{array}$ & $70,2^{1}$ & $582,3^{1}$ & 0,120 & 79,7 & 783,7 & 0,102 \\
$\begin{array}{l}\text { Parcelas } \\
\text { Experimentais }\end{array}$ & 42,9 & 367,0 & 0,117 & 58,6 & 589,6 & 0,099 \\
$\begin{array}{l}\text { Quebra de } \\
\text { Produtividade }\end{array}$ & $38,9 \%$ & $37,0 \%$ & & $26,5 \%$ & $24,8 \%$ & \\
\hline
\end{tabular}

${ }^{1}$ Média de 3 plantas de porte e aparência semelhante. 
A produtividade menor no tratamento Convencional se repetiu, demonstrando que os critérios adotados para a composição das parcelas extras foram justos e, portanto, a comparação é válida.

A média da massa de frutos por planta das parcelas do tratamento Convencional sofreu queda de 38,9\% em relação à média da respectiva parcela extra e no tratamento Alternativo a queda foi de $26,5 \%$. Em relação ao volume de frutos a quebra também foi maior no tratamento Convencional, 37,0\% contra 24,8\%. O percentual menor na quebra de massa e quantidade de frutos em relação ao tratamento Convencional indica que as plantas do tratamento Alternativo toleraram melhor o estresse provocado pelas amostragens.

O desbaste de fruto no início da frutificação no tratamento Alternativo, prática não realizada pelo receio da queda de frutos observada no ano anterior nas mesmas parcelas, poderia ter garantido melhor tamanho dos frutos.

\subsubsection{Teores de sólidos solúveis $\left({ }^{\circ}\right.$ brix) e acidez total}

Em 2002 não houve diferenças significativas entre os tratamentos para o quesito qualidade dos frutos, sendo que, as médias de brix, acidez total e 'ratio' foram melhores do que os padrões para o tangor 'Murcott', brix 12,6\%, acidez 0,92\% e 'ratio' de 13,7, definidos por Figueiredo (1991).

Em 2003 as médias de brix do tratamento Alternativo e do Convencional não apresentaram diferenças significativas entre si e se mantiveram próximas aos padrões para a fruta. No entanto, no tratamento Alternativo a acidez total ficou elevada, e consequentemente o 'ratio' ficou baixo, em relação ao tratamento Convencional diferindo significativamente. As médias de brix, acidez total, 'ratio' e peso médio dos frutos do tratamento Convencional se apresentaram dentro dos padrões da literatura.

Semelhante à avaliação de 2003, os teores de brix, em 2004, não diferiram estatisticamente entre os tratamentos e os valores permaneceram próximos aos padrões de literatura. Já no quesito acidez e 'ratio' as médias do tratamento Alternativo ficaram fora dos padrões para o tangor 'Murcott' e também em relação ao tratamento 
Convencional com diferenças significativas. A insuficiência de $\mathrm{K}$ e a falta do desbaste de frutos na época apropriada podem ter prejudicado os resultados em peso médio dos frutos e acidez total no tratamento Alternativo em 2004 (Tabela 11).

Tabela 11. Sólidos solúveis totais, acidez total (ácido cítrico) e 'ratio' médio de frutos de tangor 'Murcott' em dois tratamentos, Convencional e Alternativo, no período de 2002 a 2004

\begin{tabular}{ccccccc}
\hline \multirow{2}{*}{ Ano } & \multicolumn{3}{c}{ Convencional } & \multicolumn{3}{c}{ Alternativo } \\
& ${ }^{\mathbf{o}}$ Brix & Acidez total $^{1}$ & Ratio $^{2}$ & ${ }^{\mathbf{o}}$ Brix & Acidez total & Ratio \\
\hline 2002 & $13,96 \pm 0,29 \mathrm{a}$ & $0,57 \pm 0,02 \mathrm{a}$ & 24,563 & $14,50 \pm 0,20 \mathrm{a}$ & $0,58 \pm 0,02 \mathrm{a}$ & 24,940 \\
2003 & $11,70 \pm 0,20 \mathrm{a}$ & $0,76 \pm 0,03 \mathrm{~b}$ & 15,440 & $11,88 \pm 0,15 \mathrm{a}$ & $1,01 \pm 0,05 \mathrm{a}$ & 11,810 \\
2004 & $12,31 \pm 0,43 \mathrm{a}$ & $0,85 \pm 0,03 \mathrm{~b}$ & 14,550 & $11,89 \pm 0,20 \mathrm{a}$ & $1,00 \pm 0,02 \mathrm{a}$ & 11,900 \\
\hline
\end{tabular}

Letras diferentes na linha, dentro de cada época de amostragem, indicam significância pelo teste t em nível de $5 \%$ de probabilidade.

${ }^{1}$ Valores expressos em gramas de ácido cítrico para cada $100 \mathrm{ml}$ de suco.

${ }^{2}$ Valores obtidos pela divisão do ${ }^{\circ}$ Brix pela acidez total.

Apresentação: média de 10 repetições \pm erro padrão.

\subsection{Outras avaliações}

\subsubsection{Fitomassa na entrelinha}

O volume de fitomassa na entrelinha do pomar no tratamento Alternativo, resultante da vegetação espontânea, foi maior do que no Convencional, sendo 107\% superior em janeiro de 2005 (Tabela 12). As aplicações de Nutri Bokashi, somado com o calcáreo e termofosfato, na entrelinha do tratamento Alternativo, são os principais responsáveis pela expansão e vigor da vegetação espontânea. Esse resultado conferiu melhor cobertura vegetal e maior volume de palhada ao tratamento Alternativo, convergindo com os objetivos das recomendações de Durigan \& Pitelli (1994), Mazza et al. (2000), Sanches (2000) e Yamada et al. (2000). 
Tabela 12. Quantidade de massa fresca da vegetação espontânea na entrelinha de dois tratamentos, Convencional e Alternativo, em tangor 'Murcot', roçada em novembro de 2004 e avaliada em janeiro de 2005

\begin{tabular}{|c|c|c|c|}
\hline & & & $\mathbf{p}^{1}$ \\
\hline \multicolumn{4}{|c|}{ Massa fresca (g.m ${ }^{-2}$ ) } \\
\hline Fitomassa da entrelinha & $1.248,7 \pm 141,5 b$ & $2.590,7 \pm 187,1 \mathrm{a}$ & 0,0000 \\
\hline
\end{tabular}

Além do maior volume, o tratamento Alternativo também proporcionou melhor distribuição de fitomassa entre as espécies (Tabela 13). Embora o perfil da vegetação espontânea no início e durante o experimento não ter sido registrado, foi verificado visualmente que houve alterações na composição e distribuição das espécies. Alterações semelhantes na vegetação espontânea foram citadas por Sanders et al. (1995), Jordan et al. (2000) e Koide \& Dickie (2002) como conseqüência da interação dos FMAs nativos com a comunidade vegetal espontânea.

O volume maior de fitomassa, no tratamento Alternativo, também proporcionou maiores quantidades de gramíneas perenes que, provavelmente, favoreceram a melhoria no estado de compactação em relação ao tratamento Convencional. Para Oades (1984) e Sanches (2000) as gramíneas perenes são as mais indicadas para recuperar e proteger as propriedades físicas do solo devido ao seu sistema radicular agressivo. Resultados de recuperação e preservação dos agregados de solo por gramíneas perenes foram observados por Silva e Mielniczuck (1997a), Silva e Mielniczuck (1997b) e Rizzo (2000).

Apesar da visível diferença de diversidade de espécies ocorrentes na linha de tangor 'Murcott' entre os tratamentos, por dificuldades operacionais não foi possível sincronizar o mesmo período de aplicação do herbicida na linha do tratamento Convencional e o roço na linha do tratamento Alternativo, impossibilitando, assim, a comparação da fitomassa nesse local. 
Tabela 13. Espécies ocorrentes e respectivas massa fresca, em g.m ${ }^{-2}$, da vegetação espontânea na entrelinha de dois tratamentos, Convencional e Alternativo, em tangor 'Murcot' apurada em janeiro de 2005

\begin{tabular}{|c|c|c|c|}
\hline Espécies ocorrentes & Nome comum & $\begin{array}{r}\text { Convencional } \\
\text { Massa fr }\end{array}$ & $\begin{array}{l}\text { Alternativo } \\
\left.\text { (g. } \mathbf{~ m}^{-2}\right)\end{array}$ \\
\hline Alternanthera ficoidea (L.) & apaga-fogo & 3,3 & $1.933,3$ \\
\hline Bidens pilosa $L$. & picão preto & 6,7 & 246,7 \\
\hline Brachiaria decumbens Stapt & capim braquiária & $2.070,0$ & $2.206,7$ \\
\hline Chamaesyce hirta (L.) Millsp & erva santa luzia & - & 103,3 \\
\hline Commelina benghalensis $L$. & trapoeraba & 3,3 & - \\
\hline Cynodon dactylon & grama seda & 340,0 & - \\
\hline Cyperus sp. & tiririca & 250,0 & 136,7 \\
\hline Digitaria horizontalis Wild & capim colchão & 866,7 & 16,7 \\
\hline Digitaria insularis (L.) Fedde & capim amargoso & - & $1.100,0$ \\
\hline Emilia sanchifolia (L.) DC. & falsa serralha & - & 3,3 \\
\hline Euphorbia heterophylla (L.) & amendoim bravo & 26,7 & 120,0 \\
\hline Panicum maximum Jacq. & capim colonião & - & $2.046,7$ \\
\hline Paspalum notatum Flugge & grama batatais & - & $2.123,3$ \\
\hline Paspalum paniculatum L. & grama touceira & $8.310,0$ & $15.786,7$ \\
\hline Phyllantus tenellus Roxb. & quebra pedra & 3,3 & - \\
\hline Portulaca oleracea L. & beldroega & - & 23,3 \\
\hline Sida ssp. & guanxuma & 133,3 & 60,0 \\
\hline Talinum paniculatum (Jacq.) G. & maria gorda & 80,0 & - \\
\hline Brachiaria arrecta & tanner grass & 393,3 & - \\
\hline
\end{tabular}




\subsection{2 Ácaro da falsa ferrugem}

O ácaro da falsa ferrugem (Phyllocoptruta oleivora) apresentou maior incidência entre os períodos de janeiro e março de 2003 e 2004 no tratamento Alternativo, coincidindo com a época de maior demanda nutricional, demonstrando uma possível correlação entre nutrição e suscetibilidade a pragas (Figura 8). Na maioria das avaliações os níveis de incidências no tratamento Alternativo foram equiparáveis ao tratamento Convencional, mesmo não havendo a aplicação de acaricidas específicos.

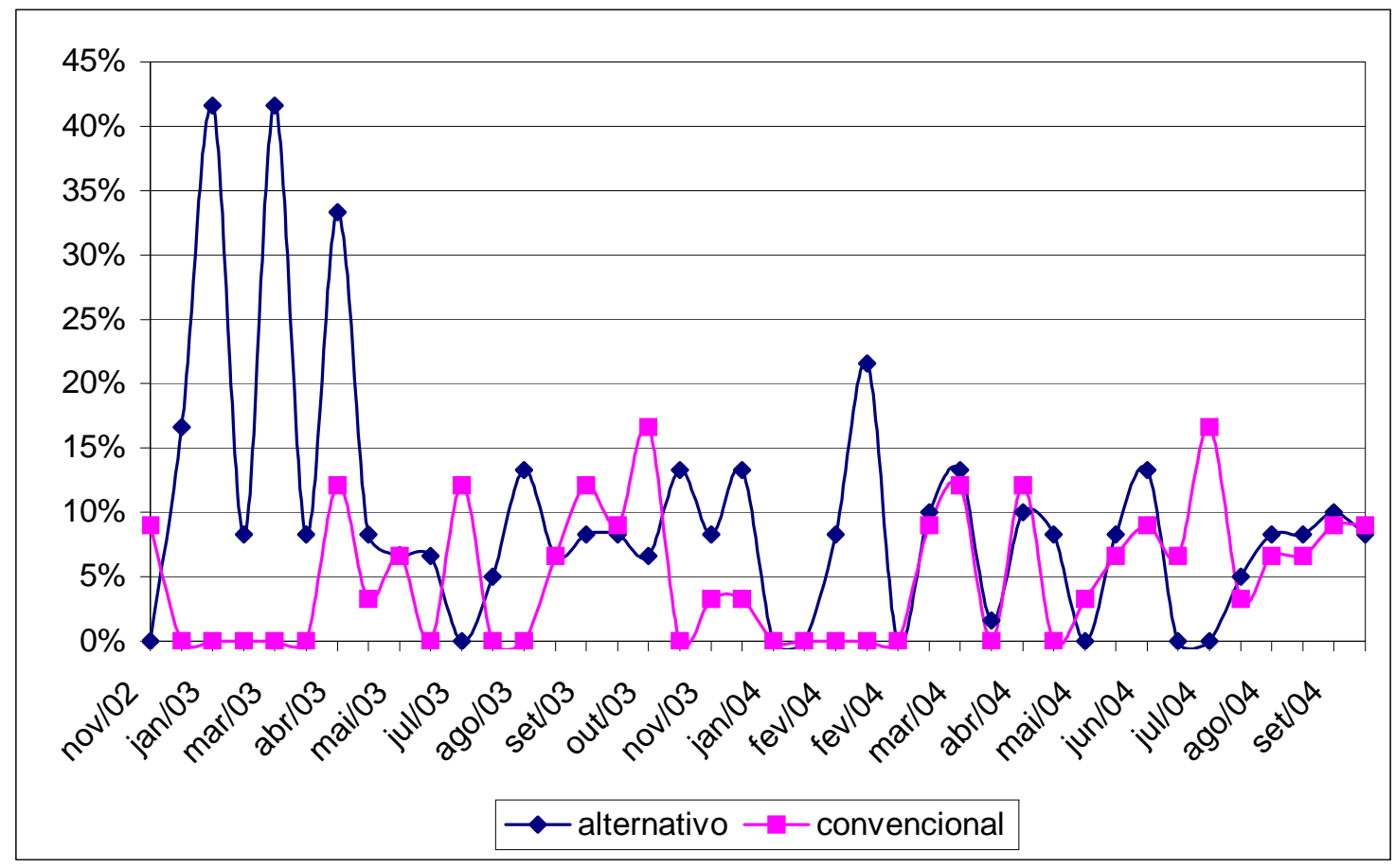

Figura 8 - Flutuação populacional de ácaro da falsa ferrugem (Phyllocoptruta oleivora) em plantas de tangor 'Murcott' em dois tratamentos, Convencional e Alternativo, no período de novembro de 2002 a setembro de 2004. Dados fornecidos pelo proprietário

\subsubsection{Ortézia}

Foi observada incidência significativamente menor de ortézia (Orthezia praelonga) na área de tratamento Alternativo (0,54\%) em relação ao tratamento convencional (14,06\%) (Tabela 14). A ausência de aplicação de fungicidas no tratamento Alternativo pode ter favorecido a presença de inimigos naturais da ortézia. 
A ortézia, classificado como praga secundária na década de 80 (Gravena, 1984), é considerada atualmente como a que mais dano pode provocar ao citros no Brasil, devido à facilidade com que adquire resistência aos inseticidas (Gravena, 1999). O uso intensivo de inseticidas e fungicidas, além de gerar populações resistentes, prejudica os insetos predadores e os fungos benéficos, que exercem o controle biológico pressionando a população de ortézia mantendo-a equilibrada, segundo Benvenga (2002).

Tabela 14. Incidência de Orthezia praelonga verificada em 9 linhas de tangor 'Murcott' dos tratamentos Convencional e Alternativo da área experimental, no período de julho de 2003 a agosto de 2004, apurado através do MIP (Manejo Integrado de Pragas) aplicado na propriedade

\begin{tabular}{ccccc}
\hline & \multicolumn{2}{c}{ Convencional } & \multicolumn{2}{c}{ Alternativo } \\
& $\mathbf{N}^{\mathbf{0}}$ de plantas & Plantas atacadas & $\mathbf{N}^{\mathbf{0}}$ de plantas & Plantas atacadas \\
\hline linha 1 & 43 & 6 & 45 & 0 \\
linha 2 & 43 & 4 & 45 & 0 \\
linha 3 & 42 & 4 & 45 & 0 \\
linha 4 & 42 & 5 & 46 & 2 \\
linha 5 & 40 & 3 & 46 & 0 \\
linha 6 & 41 & 6 & 46 & 0 \\
linha 7 & 44 & 11 & 42 & 0 \\
linha 8 & 43 & 8 & 35 & 0 \\
linha 9 & 39 & 6 & 19 & 0 \\
Total & 377 & 53 & 369 & 2 \\
Incidência (\%) & & $\mathbf{1 4 , 0 6 \%}$ & & $\mathbf{0 , 5 4 \%}$ \\
\hline
\end{tabular}




\section{CONCLUSÕES}

Pelos dados obtidos neste experimento podemos concluir que:

- O manejo alternativo, com aplicação de composto fermentado Bokashi, principalmente nas entrelinhas, favoreceu a cobertura vegetal nessa faixa do pomar, que se apresentou 107,5\% superior em janeiro de 2005;

- Houve redução na resistência do solo à penetração na linha e entrelinha do tratamento Alternativo, em relação ao tratamento Convencional, ao longo do experimento, denotando melhora no estado de compactação do solo, muito provavelmente pelo efeito da maior cobertura vegetal obtida, principalmente de gramíneas;

- Imagens digitalizadas e tratadas pelo SIARCS indicam que houve melhor desenvolvimento do sistema radicular superficial do tangor 'Murcott' com o tratamento Alternativo, quando comparado com o tratamento Convencional;

- O índice de colonização radicular de FMAs nativos nas plantas do tangor 'Murcott', que inicialmente se apresentavam semelhantes nos dois tratamentos, próximos a $62 \%$, foi maior no tratamento Alternativo, em média $70 \%$, ao passo que no tratamento Convencional a média se situou em torno de $63 \%$ ao longo do experimento. Da mesma forma a quantidade de esporos viáveis no solo foi maior, pois a partir da avaliação de agosto de 2003, as médias do tratamento Alternativo foram cerca de $23 \%$ maiores em relação ao tratamento Convencional em todas as avaliações; 
- A quantidade aportada de K no tratamento Alternativo não foi suficiente para suprir adequadamente as necessidades das plantas, demonstrando que é preciso dar maior atenção a esse nutriente nas propostas alternativas de manejo para citros;

- O teor de B foliar se apresentou significativamente superior e em níveis crescentes nas plantas submetidas ao manejo Alternativo ao longo do período experimental, atingindo níveis $280 \%$ maiores do que o tratamento Convencional, com teores de até $161,35 \mathrm{mg} \cdot \mathrm{kg}^{-1}$, resultado altamente desejável para este nutriente em citros;

- Apesar da redução na produtividade inicialmente, o tratamento Alternativo foi superior em massa de frutos por planta na última avaliação, em agosto de 2004, sendo 58,2 kg. planta ${ }^{-1}$ contra 42,9 kg.planta ${ }^{-1}$ do Convencional, embora o tamanho dos frutos e a acidez total tenham sido prejudicados pela deficiência do $\mathrm{K}$. Isso demonstra que em pomar de idade avançada o manejo alternativo deve ser adotado de forma gradual;

- O manejo alternativo proporcionou maior equilíbrio na população de Orthezia praelonga, apresentando $0,54 \%$ das plantas atacadas, contra $14,06 \%$ no manejo Convencional ao longo do período experimental.

De um modo geral, para confirmar a viabilidade do manejo alternativo em citros é necessário desenvolver mais pesquisas, principalmente as que tratam das interações dos fatores biológicos no ecossistema citrícola em prol da produção ecologicamente correta e economicamente viável. Ainda que os resultados deste experimento não possam apurar a fórmula definitiva para a citricultura sustentável, certamente servirão de subsídios aos trabalhos que estiverem em busca de novas alternativas para a citricultura. 
ANEXOS 
CONVENCIONAL

\begin{tabular}{|c|c|c|c|}
\hline mês & fitossanitários & Adubação/correção & controle de mato \\
\hline 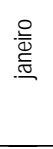 & $\begin{array}{l}\text { 1,6 I carbendazim } \\
3,3 \mathrm{~kg} \text { mancozeb } \\
\text { 13,0 I óleo mineral } \\
\end{array}$ & \begin{tabular}{|l|}
4,4 I nutr. quelat. foliar \\
$178,5 \mathrm{~kg}$ Nitrato de Potássio \\
\end{tabular} & roçadeira \\
\hline 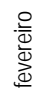 & & & \\
\hline 总 & 3,6 kg Enxofre & $\begin{array}{l}\text { 2,3 I nutriente foliar(c) } \\
\text { 0,65 kg Ác. Bórico }\end{array}$ & roçadeira \\
\hline$\frac{\overline{\bar{c}}}{\bar{\tau}}$ & $\begin{array}{l}\text { 13,0 I óleo mineral } \\
\text { 3,6 kg Enxofre }\end{array}$ & $1,62 \mathrm{~kg}$ nutr. foliar(a) & $\begin{array}{l}2,0 \text { I glifosate(a) } \\
\text { roçadeira }\end{array}$ \\
\hline$\frac{\circ}{\stackrel{\widetilde{\tau}}{E}}$ & & 800 kg calcáreo & \\
\hline 옫 & $\begin{array}{l}\text { 3,6 kg enxofre } \\
13,0 \text { I óleo mineral } \\
1,3 \text { I decis }\end{array}$ & $1,62 \mathrm{~kg}$ nutr. foliar(a) & roçadeira \\
\hline 올 & $\begin{array}{l}\text { 13,0 I óleo mineral } \\
3,25 \text { I methidathion } \\
3,6 \mathrm{~kg} \text { enxofre }\end{array}$ & $1,62 \mathrm{~kg}$ nutr. foliar(a) & \\
\hline 品 & $\begin{array}{l}\text { 13,0 I óleo mineral } \\
1,3 \text { I decis }\end{array}$ & & \\
\hline 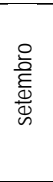 & \begin{tabular}{|l|}
$3,6 \mathrm{~kg}$ enxofre \\
\\
$3,4 \mathrm{~kg}$ oxicloreto $\mathrm{Cu}$ \\
2,3 I dimetoato \\
\end{tabular} & $\begin{array}{l}14,6 \text { kg ureia } \\
4,4 \text { I nutr. quelat. foliar } \\
178,5 \mathrm{~kg} \text { Nitrato de Potássio } \\
4,4 \text { I nutr. quelat. foliar } \\
178,5 \mathrm{~kg} \text { Nitrato de Potássio } \\
14,6 \mathrm{~kg} \text { ureia } \\
\end{array}$ & \\
\hline $\begin{array}{l}\text { 을 } \\
\text { 롱 }\end{array}$ & $\begin{array}{l}\text { 3,6 kg enxofre } \\
\text { 13,0 I óleo mineral } \\
\text { 2,3 I dimetoato }\end{array}$ & $\begin{array}{l}14,6 \mathrm{~kg} \text { ureia } \\
2,3 \text { I nutriente foliar(c) } \\
2,6 \mathrm{~kg} \text { foliar } 00-30-20\end{array}$ & \\
\hline 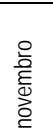 & \begin{tabular}{|l|}
0,4 I abamectin \\
1,6 I carbendazim \\
3,4 kg oxicloreto $\mathrm{Cu}$ \\
13,0 I óleo mineral
\end{tabular} & $\begin{array}{l}\text { 2,3 I nutriente foliar(c) } \\
178,5 \mathrm{~kg} \text { Nitrato de Potássio }\end{array}$ & \\
\hline $\begin{array}{l}\text { 은 } \\
\text { 를 } \\
\text { N } \\
\text { d }\end{array}$ & $\begin{array}{l}\text { 13,0 I óleo mineral } \\
\text { 1,3 I deltametrina } \\
\text { 13,0 I óleo mineral } \\
\text { 3,3 kg mancozeb } \\
\text { 1,6 I carbendazim }\end{array}$ & $\begin{array}{l}2,6 \text { kg foliar 00-30-20 } \\
0,65 \mathrm{~kg} \text { Ác. Bórico } \\
\text { 178,5 kg Nitrato de Potássio } \\
\text { 71,4 kg Cloreto de Potássio } \\
\text { 2,3 I nutriente foliar(c) } \\
\text { 178,5 kg Nitrato de Potássio }\end{array}$ & $\begin{array}{l}3,25 \text { I glifosate(b) } \\
\text { roçadeira }\end{array}$ \\
\hline
\end{tabular}

ALTERNATIVO

\begin{tabular}{|c|c|c|c|}
\hline mês & fitossanitários & adubação/correção & controle de mato \\
\hline $\begin{array}{l}\text { 옾 } \\
\text { 胥 }\end{array}$ & & & roçadeira \\
\hline 爱 & & $\begin{array}{l}5 \text { I extrato aquoso bokashi } \\
850 \text { kg Nutri Bokashi }\end{array}$ & \\
\hline 总 & & $\begin{array}{l}5 \text { I extrato aquoso bokashi } \\
850 \mathrm{~kg} \text { Nutri Bokashi }\end{array}$ & roçadeira \\
\hline 言 & 3,6 kg Enxofre & $\begin{array}{l}5 \text { I extrato aquoso bokashi } \\
850 \text { kg Nutri Bokashi }\end{array}$ & \\
\hline 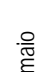 & & $\begin{array}{l}51 \text { extrato aquoso bokashi } \\
850 \mathrm{~kg} \text { Nutri Bokashi }\end{array}$ & roçadeira \\
\hline 哭 & & $\begin{array}{l}5 \text { I extrato aquoso bokashi } \\
850 \mathrm{~kg} \text { Nutri Bokashi }\end{array}$ & \\
\hline 올 & $\begin{array}{l}3,6 \mathrm{~kg} \text { Enxofre } \\
9,0 \mathrm{~kg} \text { cal }\end{array}$ & 5 I extrato aquoso bokashi & \\
\hline $\begin{array}{l}\text { 号 } \\
\text { 兽 }\end{array}$ & & 5 I extrato aquoso bokashi & \\
\hline 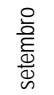 & & 5 I extrato aquoso bokashi & \\
\hline $\begin{array}{l}\text { 을 } \\
\text { 言 }\end{array}$ & $\begin{array}{l}18 \mathrm{~kg} \text { calda bordalesa } \\
3,6 \mathrm{~kg} \text { Enxofre } \\
9,0 \mathrm{~kg} \text { cal }\end{array}$ & & \\
\hline 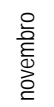 & $18 \mathrm{~kg}$ calda bordalesa & $\begin{array}{l}5 \text { I extrato aquoso bokashi } \\
850 \mathrm{~kg} \text { Nutri Bokashi }\end{array}$ & \\
\hline 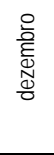 & $\begin{array}{l}18 \mathrm{~kg} \text { calda bordalesa } \\
3,6 \mathrm{~kg} \text { Enxofre } \\
9,0 \mathrm{~kg} \text { cal }\end{array}$ & 5 I extrato aquoso bokashi & roçadeira \\
\hline
\end{tabular}

Quadro 1 - Descrição dos controles fitossanitários, adubações e correções e controle de mato dos tratamentos Convencional e Alternativo no ano de 2002. Dosagens do produto comercial contendo o ingrediente ativo relacionado por 1 ha de área 

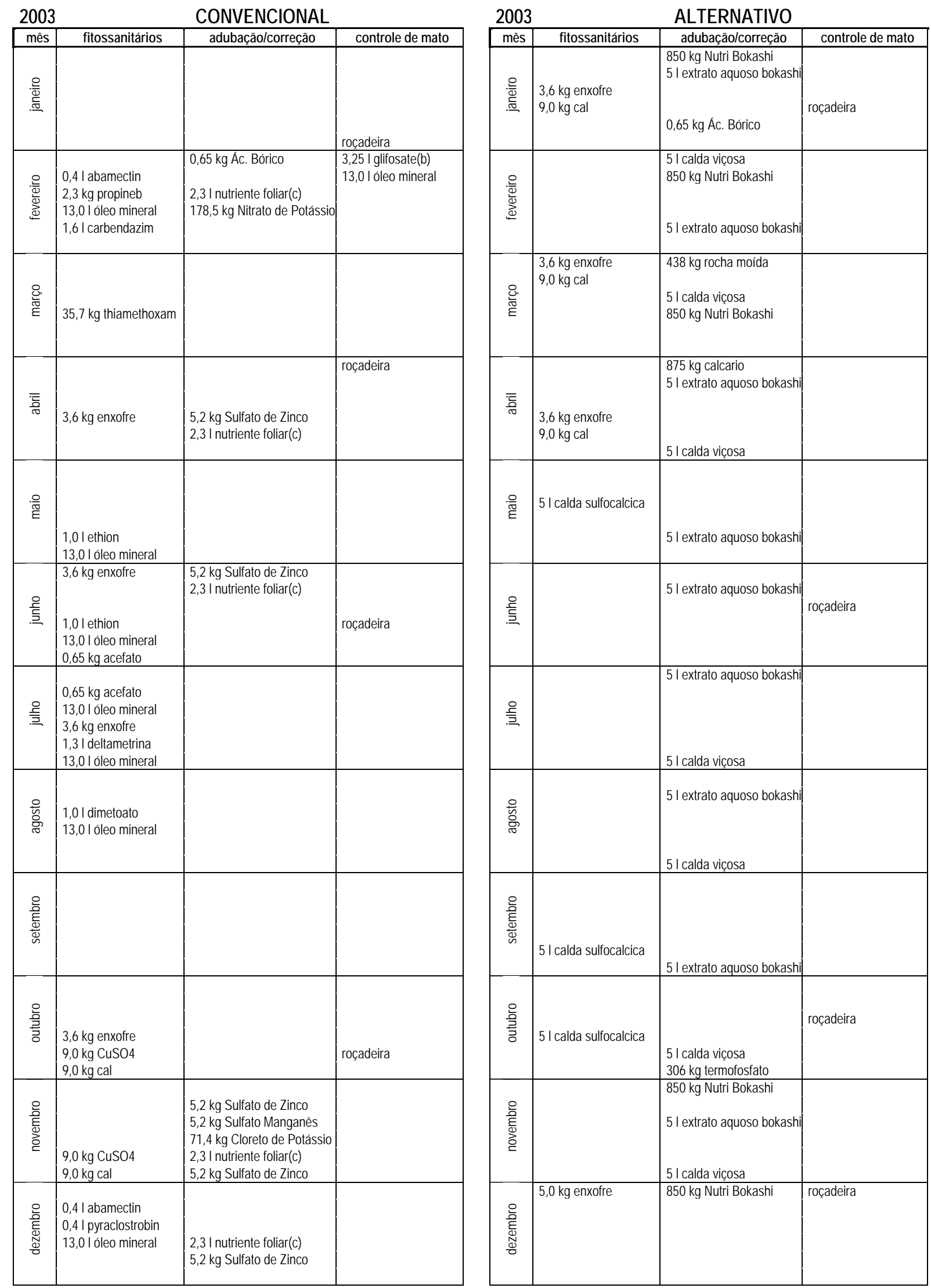

Quadro 2 - Descrição dos controles fitossanitários, adubações e correções e controle de mato dos tratamentos Convencional e Alternativo no ano de 2003. Dosagens do produto comercial contendo o ingrediente ativo relacionado por 1 ha de área 
2004CONVENCIONAL

\begin{tabular}{|c|c|c|c|}
\hline mês & fitossanitários & adubação/correção & controle de mato \\
\hline 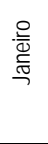 & $\begin{array}{l}7 \mathrm{~kg} \mathrm{cal} \\
7 \mathrm{~kg} \text { CuSO} 4\end{array}$ & & \\
\hline 爱 & & $\begin{array}{l}10 \mathrm{~kg} \text { cloreto de potassio } \\
500 \mathrm{~g} \text { Sulfato de Zinco } \\
1 \text { I nutriente foliar (c) }\end{array}$ & roçadeira \\
\hline 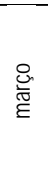 & $\begin{array}{l}5,0 \mathrm{~kg} \text { enxofre } \\
5,0 \mathrm{~kg} \text { enxofre } \\
1 \mathrm{~kg} \text { acefato }\end{array}$ & $\begin{array}{l}3 \mathrm{~kg} \text { Acido borico } \\
10 \mathrm{~kg} \text { Cloreto de Potássio } \\
1 \text { I nutriente foliar ( c) } \\
500 \text { g Sulfato de Zinco } \\
200 \text { g Cloreto potassio }\end{array}$ & 3,5 I Glifosato \\
\hline$\overline{\bar{c}}$ & $\begin{array}{l}500 \mathrm{ml} \text { deltametrina } \\
5,0 \mathrm{~kg} \text { enxofre }\end{array}$ & & roçadeira \\
\hline$\stackrel{\circ}{\stackrel{\circ}{\widetilde{N}}}$ & 2 I dimetoato & & \\
\hline 宊 & $1 \mathrm{~kg}$ acefato & & \\
\hline 을 & $5,0 \mathrm{~kg}$ enxofre & & \\
\hline $\begin{array}{l}\text { 莺 } \\
\text { 兽 }\end{array}$ & $\begin{array}{l}7 \mathrm{~kg} \text { cal } \\
7 \mathrm{~kg} \text { CuSO } 4\end{array}$ & & roçadeira \\
\hline 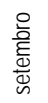 & & & \\
\hline $\begin{array}{l}\text { 을 } \\
\text { 름 }\end{array}$ & $\begin{array}{l}7 \mathrm{~kg} \mathrm{cal} \\
7 \mathrm{~kg} \mathrm{CuSO} 4 \\
5,0 \mathrm{~kg} \text { enxofre }\end{array}$ & 71,4 kg KCl & \\
\hline 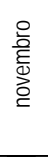 & $\begin{array}{l}0,4 \text { I abamectin } \\
7 \mathrm{~kg} \text { CuSO } 4 \\
13,0 \text { I óleo mineral } \\
\end{array}$ & 1,8 I nutriente foliar(c) & roçadeira \\
\hline $\begin{array}{l}\text { 을 } \\
\text { E్ } \\
\mathbb{N} \\
\frac{\mathbb{O}}{0}\end{array}$ & $\begin{array}{l}7 \mathrm{~kg} \mathrm{cal} \\
7 \mathrm{~kg} \text { CuSO } 4 \\
7 \mathrm{~kg} \mathrm{cal} \\
7 \mathrm{~kg} \text { CuSO } 4 \\
5,0 \mathrm{~kg} \text { enxofre }\end{array}$ & & \\
\hline
\end{tabular}

2004 ALTERNATIVO

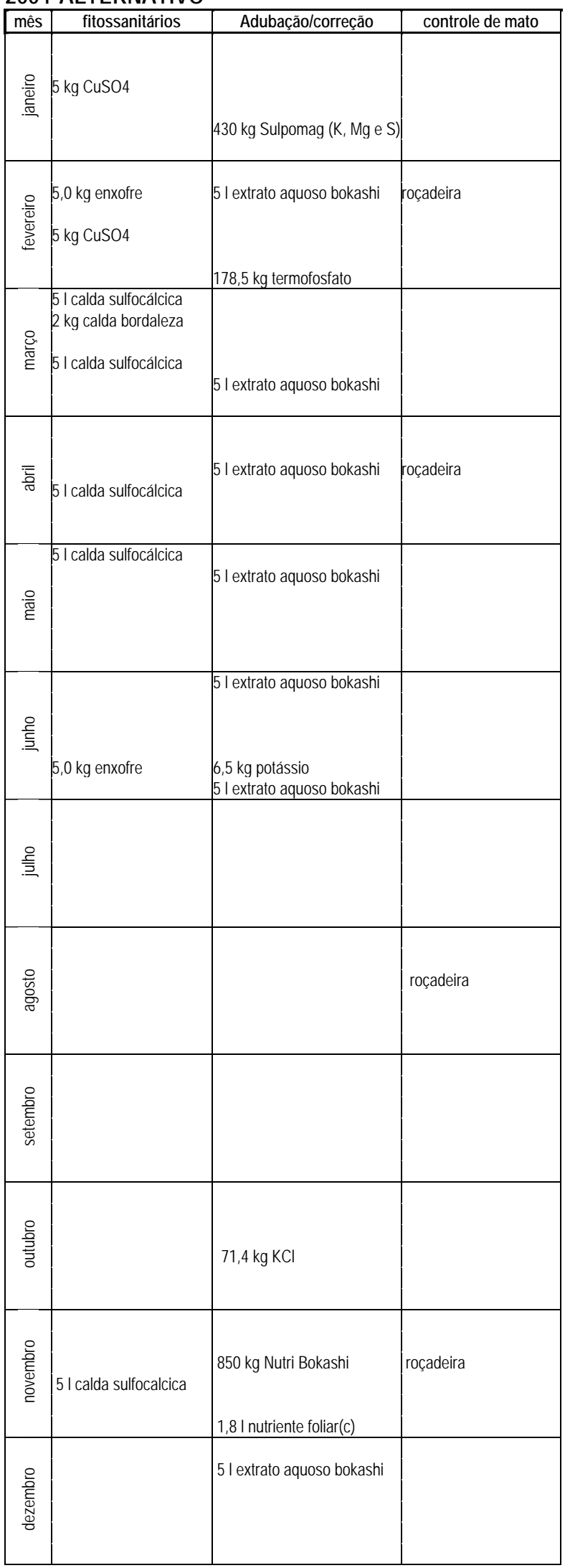

Quadro 3 - Descrição dos controles fitossanitários, adubações e correções e controle de mato dos tratamentos Convencional e Alternativo no ano de 2004. Dosagens do produto comercial contendo o ingrediente ativo relacionado por 1 ha de área 


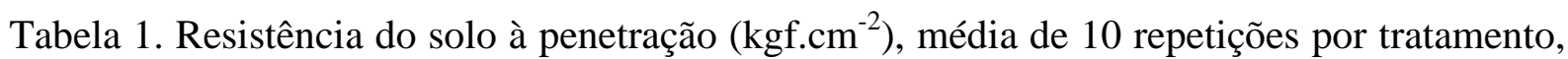
a cada 5 cm de profundidade, em 3 posições da linha, nos anos de 2002 a 2004

\begin{tabular}{|c|c|c|c|c|c|c|c|c|c|}
\hline \multirow[b]{2}{*}{$\begin{array}{c}\text { Profundidade } \\
\text { cm }\end{array}$} & \multicolumn{3}{|c|}{2002} & \multicolumn{3}{|c|}{2003} & \multicolumn{3}{|c|}{2004} \\
\hline & \multicolumn{2}{|c|}{ kgf. cm $^{-2}$} & $\mathbf{P}^{1}$ & \multicolumn{2}{|c|}{ kgf. $\mathbf{c m}^{-2}$} & $\mathbf{P}$ & \multicolumn{2}{|c|}{ kgf. $\mathbf{c m}^{-2}$} & $\mathbf{P}$ \\
\hline \multicolumn{10}{|l|}{ LINHA 1} \\
\hline 5 & 64,9 & 65,3 & 0,974 & 54,8 & 54,2 & 0,862 & 16,0 & 12,4 & 0,111 \\
\hline 10 & 43,3 & 52,8 & 0,481 & 27,8 & 23,9 & 0,161 & 20,6 & 16,6 & 0,066 \\
\hline 15 & 46,5 & 70,8 & 0,159 & 31,0 & 25,5 & 0,160 & 19,9 & 16,6 & 0,097 \\
\hline 20 & 61,1 & 71,8 & 0,448 & 35,7 & 33,7 & 0,675 & 19,5 & 16,4 & 0,135 \\
\hline 25 & 65,7 & 71,5 & 0,660 & 41,7 & 44,9 & 0,731 & 20,4 & 17,1 & 0,110 \\
\hline 30 & 60,1 & 74,8 & 0,252 & 50,8 & 57,3 & 0,554 & 23,0 & 21,4 & 0,547 \\
\hline 35 & 62,5 & 72,9 & 0,176 & 56,8 & 72,8 & 0,192 & 24,6 & 24,7 & 0,990 \\
\hline 40 & 57,6 & 78,1 & 0,025 & 63,2 & 75,9 & 0,310 & 26,5 & 28,1 & 0,579 \\
\hline 45 & 55,7 & 72,5 & 0,030 & 64,7 & 73,2 & 0,182 & 27,6 & 31,4 & 0,124 \\
\hline 50 & 52,1 & 73,8 & 0,011 & 65,1 & 68,4 & 0,642 & 27,9 & 32,1 & 0,116 \\
\hline 55 & 49,2 & 61,5 & 0,066 & 64,0 & 69,5 & 0,514 & 28,7 & 30,8 & 0,428 \\
\hline 60 & 45,9 & 66,8 & 0,014 & 63,1 & 63,2 & 0,998 & 30,1 & 30,7 & 0,855 \\
\hline \multicolumn{10}{|l|}{ LINHA 2} \\
\hline 5 & 56,5 & 62,5 & 0,409 & 63,9 & 53,3 & 0,030 & 26,5 & 21,5 & 0,161 \\
\hline 10 & 27,3 & 30,6 & 0,607 & 35,2 & 39,7 & 0,477 & 30,3 & 24,7 & 0,143 \\
\hline 15 & 31,8 & 35,2 & 0,662 & 43,4 & 61,0 & 0,120 & 32,2 & 29,2 & 0,540 \\
\hline 20 & 32,0 & 40,8 & 0,302 & 47,4 & 87,8 & 0,012 & 36,1 & 35,7 & 0,955 \\
\hline 25 & 35,0 & 50,5 & 0,101 & 50,3 & 96,6 & 0,005 & 41,3 & 39,1 & 0,775 \\
\hline 30 & 35,9 & 59,2 & 0,006 & 55,3 & 102,0 & 0,008 & 44,3 & 43,0 & 0,871 \\
\hline 35 & 36,0 & 59,2 & 0,007 & 73,3 & 97,9 & 0,078 & 44,9 & 43,9 & 0,909 \\
\hline 40 & 33,1 & 60,2 & 0,001 & 79,9 & 88,9 & 0,424 & 46,3 & 46,0 & 0,975 \\
\hline 45 & 31,8 & 58,8 & 0,000 & 69,2 & 80,5 & 0,362 & 46,8 & 48,5 & 0,833 \\
\hline 50 & 34,4 & 55,1 & 0,002 & 69,0 & 67,4 & 0,892 & 46,6 & 46,0 & 0,927 \\
\hline 55 & 35,1 & 51,8 & 0,009 & 71,3 & 72,1 & 0,942 & 44,2 & 45,5 & 0,830 \\
\hline 60 & 32,3 & 50,8 & 0,005 & 70,2 & 70,6 & 0,962 & 43,4 & 44,8 & 0,800 \\
\hline \multicolumn{10}{|l|}{ LINHA 3} \\
\hline 5 & 60,2 & 66,1 & 0,442 & 64,1 & 65,0 & 0,832 & 41,2 & 32,9 & 0,150 \\
\hline 10 & 49,8 & 55,8 & 0,714 & 53,7 & 54,3 & 0,943 & 53,4 & 45,6 & 0,291 \\
\hline 15 & 56,6 & 65,8 & 0,546 & 80,7 & 99,6 & 0,161 & 51,7 & 47,6 & 0,540 \\
\hline 20 & 50,8 & 84,4 & 0,025 & 103,6 & 125,1 & 0,192 & 53,5 & 48,8 & 0,457 \\
\hline 25 & 52,7 & 85,6 & 0,022 & 113,8 & 125,3 & 0,555 & 51,6 & 48,1 & 0,510 \\
\hline 30 & 54,6 & 84,1 & 0,014 & 108,9 & 99,8 & 0,594 & 49,3 & 43,3 & 0,212 \\
\hline 35 & 50,6 & 71,0 & 0,044 & 95,9 & 113,5 & 0,416 & 51,4 & 41,9 & 0,215 \\
\hline 40 & 48,9 & 71,0 & 0,014 & 101,4 & 95,3 & 0,652 & 46,1 & 43,5 & 0,588 \\
\hline 45 & 51,3 & 64,7 & 0,086 & 95,2 & 93,2 & 0,859 & 48,2 & 43,4 & 0,417 \\
\hline 50 & 50,0 & 62,5 & 0,067 & 94,1 & 89,4 & 0,614 & 47,9 & 42,6 & 0,261 \\
\hline 55 & 49,3 & 59,5 & 0,073 & 88,9 & 84,4 & 0,594 & 47,5 & 41,9 & 0,241 \\
\hline 60 & 46,9 & 53,9 & 0,144 & 80,3 & 79,3 & 0,896 & 47,1 & 41,5 & 0,266 \\
\hline
\end{tabular}

\footnotetext{
${ }^{1}$ Probabilidade de que as diferenças sejam nulas pelo teste $\mathrm{t}$.
} 
Tabela 2. Resistência do solo à penetração $\left(\mathrm{kgf.cm}^{-2}\right)$, média de 10 repetições por tratamento, a cada 5 cm de profundidade, em 3 posições da entrelinha, nos anos de 2002 a 2004

\begin{tabular}{|c|c|c|c|c|c|c|c|c|c|}
\hline $\begin{array}{c}\text { Profundidade } \\
\text { cm } \\
\end{array}$ & $\begin{array}{r}\text { Conv. } \\
\text { kgf. }\end{array}$ & $\begin{array}{l}2002 \\
\text { Alter. } \\
\mathrm{cm}^{-2} \\
\end{array}$ & $\mathbf{P}^{1}$ & $\begin{array}{r}\text { Conv. } \\
\text { kgf. }\end{array}$ & $\begin{array}{l}2003 \\
\text { Alter. } \\
\mathrm{cm}^{-2} \\
\end{array}$ & $\mathbf{P}$ & $\begin{array}{r}\text { Conv. } \\
\text { kgf. }\end{array}$ & $\begin{array}{l}2004 \\
\text { Alter. } \\
\mathrm{cm}^{-2} \\
\end{array}$ & $\mathbf{P}$ \\
\hline \multicolumn{10}{|l|}{ ENTRELINHA 1} \\
\hline 5 & 113,1 & 115,2 & 0,906 & 50,8 & 68,7 & 0,164 & 59,8 & 56,4 & 0,692 \\
\hline 10 & 129,8 & 149,6 & 0,409 & 39,9 & 79,4 & 0,008 & 70,5 & 69,7 & 0,908 \\
\hline 15 & 110,5 & 136,5 & 0,244 & 90,5 & 126,9 & 0,030 & 66,3 & 66,6 & 0,965 \\
\hline 20 & 90,1 & 127,3 & 0,039 & 115,3 & 135,5 & 0,205 & 60,2 & 64,4 & 0,375 \\
\hline 25 & 81,8 & 106,2 & 0,084 & 123,9 & 131,7 & 0,629 & 55,3 & 62,9 & 0,064 \\
\hline 30 & 68,6 & 90,2 & 0,082 & 128,8 & 119,4 & 0,621 & 55,9 & 61,6 & 0,124 \\
\hline 35 & 53,7 & 75,1 & 0,037 & 113,1 & 111,7 & 0,932 & 55,2 & 59,2 & 0,171 \\
\hline 40 & 49,7 & 67,9 & 0,084 & 107,4 & 107,2 & 0,984 & 55,9 & 57,4 & 0,660 \\
\hline 45 & 43,0 & 55,9 & 0,131 & 101,6 & 99,9 & 0,890 & 55,8 & 57,6 & 0,572 \\
\hline 50 & 42,0 & 52,8 & 0,199 & 103,7 & 87,9 & 0,192 & 54,9 & 57,4 & 0,379 \\
\hline 55 & 37,1 & 50,4 & 0,076 & 101,4 & 86,7 & 0,203 & 57,1 & 56,6 & 0,885 \\
\hline 60 & 37,8 & 46,1 & 0,269 & 103,7 & 85,6 & 0,150 & 58,4 & 56,3 & 0,548 \\
\hline \multicolumn{10}{|l|}{ ENTRELINHA 2} \\
\hline 5 & 128,2 & 120,1 & 0,645 & 88,8 & 89,7 & 0,959 & 73,2 & 67,4 & 0,588 \\
\hline 10 & 157,3 & 140,2 & 0,438 & 93,7 & 87,0 & 0,644 & 85,3 & 76,3 & 0,373 \\
\hline 15 & 139,7 & 112,2 & 0,070 & 126,7 & 123,6 & 0,858 & 78,1 & 73,3 & 0,540 \\
\hline 20 & 108,3 & 100,5 & 0,636 & 138,7 & 171,7 & 0,103 & 72,9 & 71,2 & 0,797 \\
\hline 25 & 94,8 & 85,7 & 0,526 & 138,4 & 154,6 & 0,325 & 69,5 & 67,1 & 0,714 \\
\hline 30 & 68,8 & 76,0 & 0,527 & 127,0 & 125,4 & 0,935 & 65,1 & 64,0 & 0,859 \\
\hline 35 & 64,7 & 62,0 & 0,775 & 120,0 & 109,3 & 0,530 & 64,6 & 62,8 & 0,738 \\
\hline 40 & 53,0 & 56,6 & 0,645 & 115,9 & 117,6 & 0,924 & 64,2 & 61,7 & 0,646 \\
\hline 45 & 47,0 & 51,2 & 0,570 & 108,7 & 109,7 & 0,946 & 65,1 & 59,3 & 0,229 \\
\hline 50 & 42,9 & 47,0 & 0,546 & 104,2 & 95,3 & 0,472 & 66,6 & 60,9 & 0,250 \\
\hline 55 & 38,2 & 48,1 & 0,080 & 104,8 & 93,7 & 0,439 & 65,5 & 59,1 & 0,176 \\
\hline 60 & 37,0 & 42,9 & 0,286 & 98,8 & 82,5 & 0,237 & 67,2 & 57,1 & 0,044 \\
\hline \multicolumn{10}{|l|}{ ENTRELINHA 3} \\
\hline 5 & 130,2 & 103,1 & 0,124 & 63,2 & 81,2 & 0,054 & 49,1 & 55,0 & 0,336 \\
\hline 10 & 157,9 & 106,8 & 0,092 & 48,3 & 98,2 & 0,002 & 60,7 & 69,5 & 0,193 \\
\hline 15 & 142,3 & 96,3 & 0,080 & 72,4 & 135,6 & 0,001 & 60,0 & 71,3 & 0,057 \\
\hline 20 & 124,7 & 81,6 & 0,024 & 116,7 & 143,7 & 0,159 & 60,7 & 71,2 & 0,110 \\
\hline 25 & 103,4 & 81,8 & 0,161 & 128,0 & 147,2 & 0,230 & 58,7 & 65,2 & 0,334 \\
\hline 30 & 90,0 & 69,3 & 0,125 & 115,5 & 137,0 & 0,375 & 58,4 & 61,8 & 0,552 \\
\hline 35 & 78,5 & 62,2 & 0,157 & 100,8 & 135,0 & 0,030 & 57,9 & 60,7 & 0,575 \\
\hline 40 & 66,5 & 55,3 & 0,264 & 106,1 & 112,3 & 0,674 & 57,5 & 60,3 & 0,450 \\
\hline 45 & 57,4 & 47,1 & 0,153 & 100,8 & 106,3 & 0,661 & 58,0 & 59,9 & 0,636 \\
\hline 50 & 52,6 & 46,2 & 0,392 & 90,6 & 106,8 & 0,069 & 61,9 & 60,8 & 0,771 \\
\hline 55 & 50,0 & 42,3 & 0,269 & 91,5 & 95,7 & 0,709 & 65,4 & 60,9 & 0,229 \\
\hline 60 & 42,9 & 41,3 & 0,762 & 82,8 & 89,3 & 0,498 & 66,6 & 59,6 & 0,109 \\
\hline
\end{tabular}

\footnotetext{
${ }^{1}$ Probabilidade de que as diferenças sejam nulas pelo teste $\mathrm{t}$.
} 


\section{REFERÊNCIAS BIBLIOGRÁFICAS}

ALLEONI, L. R. F.; CAMARGO, O. A. Boron adsorption in soils from state of são Paulo, Brazil. Pesquisa Agropecuária Brasileira, v.35, n.35, p.413-421, 2000.

ARYAL, U. K.; XU, H. l. Mycorrhizal associations and their manipulations for long term agricultural stability and productivity. Nature farming and microbial applications. Journal of Crop Production, v. 3, n.1, p.285-302, 2000.

BAJWA, R.; JAVAID. A.; HANEEF, B. EM and VAM technology in Pakistan. Effect of co-inoculation of effective microrganisms (EM) and VA-mycorrhiza on plant growth and nutrient uptake in chickpea (Cicer arietnum L.). Pakistan Journal Phytopathology, v.10, p.48-52, 1998.

BAREA, J. M.; JEFFRIES, P. Arbuscular mycorrhizas in sustainable soil plant systems. In: VARMA, A.; HOCK, B. (Ed.). Mycorrhiza: structure, function, molecular biology and biotechnology. New York: Springer-Verlag, 1995. p.521-560.

BENVENGA, S. R. Manejo de cochonilha ortézia em pomares cítricos. Revista Ciência e Prática, n.5, p.8-9, 2002.

BODDINGTON, C.L.; DODD, J.C. The effect of agricultural practices on the development of indigenous arbuscular mycorrhizal fungi. I. Field studies in an Indonesian ultisol. Plant and Soil, v.218, n.1, p.137-144, 2000. 
BÖHM, W. Methods of studying root systems. New York: Springer Verlag, 1979. 190p.

BORGES, R. S.; PIO, R. M. Estudo comparativo das características dos frutos dos híbridos de tangerina: nova, murcott e ortanique, na região de Capão Bonito, SP. http://www.todafruta.com.br/todafruta/mostra conteudo.asp?conteudo=5742 fev. 2005).

BRAUN-BLANQUET, J. Plant sociology: the study of plant communities. Koenigstein: Koeltz Scientific Book, 1983, 439 p.

CAMARGO, O. A.; ALLEONI, L. R. F. Compactação do solo e o desenvolvimento das plantas. Piracicaba: Editoração Eletrônica Degaspari Designers, 1997. 132p.

CARDOSO, E. J. B. N.; FREITAS, S. S. A rizosfera. In: CARDOSO, E. J. B. N.; TSAI, S. M.; NEVES, M. C. P. (Ed.). Microbiologia do Solo. Campinas: Sociedade Brasileira de Ciência do Solo, 1992. cap.19. p.41-57.

CARDOSO, E. J. B. N., ANTUNES, V.; SILVEIRA, A. P. B.; OliVEIRA, M. H. A. Eficiência de fungos micorrízicos vesículo-arbuscular em porta enxerto de citros. Revista Brasileira de Ciência do Solo, v.10, p.25-30, 1986.

CARVAlHO, C. R. L.; MANTOVANI, D. M. B.; CARVALHO, P. R. N.; DE MORAES, R. M. Manual Técnico de Análises Químicas de Alimentos. Biblioteca do ITAL. Campinas: ITAL - Instituto de Tecnologia de Alimentos, 1990. 121p.

CARVALHO, J. E. B.; SOUZA, L. S.; JORGE, L. A. C.; RAMOS, W. F.; NETO, A. O. C.; ARAUJO, A. M. A.; LOPES, L. C.; JESUS, M. S. de Manejo de coberturas do solo e sua interferência no desenvolvimento do sistema radicular da laranja 'pêra'. Revista Brasileira de Fruticultura, v. 21, n. 2, p. 140-145, ago 1999. 
COSTA, M. B. B. Adubação Orgânica: Nova síntese e novo caminho para a agricultura. São Paulo: ICONE. 1985. 104p.

CRESTANA, S.; GUIMARÃES, M.F.; JORGE, L.A.C.; RALISCH, R.; TOZZI, C.L.; TORRE, A.; VAZ, C.M.P. Avaliação da distribuição de raízes no solo auxiliada por processamento de imagens digitais. Revista Brasileira de Ciência do Solo, v.18, p.365-371, 1994.

DEMATTÊ, J. L.; VITTI, G. C. Alguns aspectos relacionados ao manejo de solos para os citros. In: SEMINÁRIO INTERNACIONAL DE CITROS, 2., Campinas, SP, 1992. Anais. Campinas: Fundação Cargill. 1992. p.67-89.

DU PLESSIS, C. J. Relação entre elementos nutricionais, produção e qualidade dos citros. In: SEMINÁRIO INTERNACIONAL DE CITROS, 2., Campinas, SP, 1992. Anais. Campinas: Fundação Cargill, 1992. p.121-131.

DURIGAN, J. C.; PITELLI, R. A. A importância das plantas daninhas no manejo integrado de pragas da cultura de citros. In: SEMINÁRIO INTERNACIONAL DE CITROS - MIP, 3., Bebedouro, SP, 1994. Anais. Campinas: Fundação Cardill, 1994. p. 277-290.

ERIKSSON, A. Arbuscular mycorrhiza in relation to management history, soil nutrients and plant species diversity. Plant Ecology, v.155, n.2, p.129-137, 2001.

ESPELETA, J. F.; EISSENSTAT, D. M.; GRAHAM, J. H. Citrus root responses to localized drying soil: A new approach to studying mycorrhizal effects on the roots of mature trees. Plant and Soil, v.206, n.1, p.1-10, 1998. 
FIGUEIREDO, J. O. Variedades comerciais. In: RODRIGUES, O.; VIÉGAS, F.; POMPEU JÚNIOR, J.; AMARO, A. S. (Ed.). Citricultura brasileira. 2.ed. Campinas, SP: Fundação Cargill, v.1, p.228-264, 1991.

FNP CONSULTORIA \& COMÉRCIO. Agrianual 2005: Anuário da agricultura brasileira. São Paulo, 2004a. p.30-34.

FNP CONSULTORIA \& COMÉRCIO. Agrianual 2005: Anuário da agricultura brasileira. São Paulo, 2004b. p.287-290.

FNP CONSULTORIA \& COMÉRCIO. Agrianual 2005: Anuário da agricultura brasileira. São Paulo, 2004c. p.291.

FNP CONSULTORIA \& COMÉRCIO. Agrianual 2005: Anuário da agricultura brasileira. São Paulo, 2004d. p.292-320.

FORLI, F.; VITTI, G. C. Produção de silagem de capim braquiária em pomar de laranja. Piracicaba-SP, 2003. 75p. Tese (Mestrado) - Escola Superior de Agricultura "Luiz de Queiroz”, Universidade de São Paulo.

FRACARO A. A.; PEREIRA, F. M. Distribuição do sistema radicular da goiabeira 'rica' produzida a partir de estaquia herbácea. Revista Brasileira de Fruticultura, v. 26, n. 1, p.183-185, 2004.

FUNDECITRUS. Nova avaliação: PENSA/USP faz mapeamento e quantifica a importância da laranja. Revista do Fundecitrus, n.122, p.8-9, mai/jun, 2004a.

FUNDECITRUS. Europa aperta o cerco: a partir de 2005, legislação proibirá quase a metade dos produtos usados no controle de pragas na agricultura. Revista do Fundecitrus, n.123, p.14-15, jul/ago, 2004b. 
GERDEMANN, J. W.; NICOLSON, T. H. Spores of mycorryzal Endogone extracted from soil by wet sieving and decanting. Transactions of the British Mycological Society, v. 46, p.235-244, 1963.

GOLDBERG, S. Reactions of boron with soils. Plant and Soil, v.193, n.1, p.35-48, 1997.

GOMES, V. F. F; CARDOSO, E.J.B.N. Desenvolvimento de fungos micorrízicos arbusculares em três espécies de porta-enxertos cítricos sob níveis de fósforo. Piracicaba, 1997. 89p. Tese (Doutorado) - Escola Superior de Agronomia "Luiz de Queiroz”, Universidade de São Paulo.

GRAHAM, J. H.; EISSENSTAT, D. M. Field evidence for the carbon cost of citrus mycorrhizas. New Phytologisty, v.140, p.103-110, 1998.

GRAVENA, S. Manejo integrado de pragas dos citros. Laranja, n.5, p.323-361, 1984.

GRAVENA, S. Coluna do MIP - Previna-se. Contra a ortézia, só o manejo funciona. Revista Coopercitrus, n.147, p.14, 1999.

GRUPO PAULISTA DE ADUBAÇÃO E CALAGEM PARA CITROS. Recomendação de adubação e calagem para citros no Estado de São Paulo. Laranja, Edição especial, p.27, 1994.

HIGA, T. Effective microorganisms: their role in Kyusei Nature Farming and sustainable agriculture. In: INTERNATIONAL CONFERENCE ON KYUSEI NATURE FARMing, 3, Santa Bárbara, Ca, 1993. Proceedings. Washington: Agricultural Research Service/USDA, 1996. p.20-23. 
HIGA, T.; KINJO, S. Effect of lactic acid fermentation on plant growth and soil humus formation. In: INTERNATIONAL CONFERENCE ON KYUSEI NATURE FARMING, 1, Khon Kaen, 1989. Proceedings. Washington: Agricultural Research Service/USDA, 1991. p.140-147.

HIGA, T.; WIDIDANA, G.N. Changes in the soil micoflora induced by effective microrganism. In: INTERNATIONAL CONFERENCE ON KYUSEI NATURE FARMING, 1, Khon Kaen, 1989. Proceedings. Washington: Agricultural Research Service/USDA, 1991. p.153-162.

HIGA, T.; PARR, J. F. Benefficial and effective microorganisms for a sustainable agriculture. Atami: International Nature Farming Research Center, 1994. 16p.

HU, H.; BROWN, P. H. Absorption of boron by plant roots. Plant and Soil, v.193, n.1, p.49-58, 1997.

INSTITUTO DE ECONOMIA AGRÍCOLA Banco de dados IEA. http://www.iea.sp.gov.br/out/ibcoiea.php (02 fev. 2005).

JEFFRIES, P; GIANINAZZI, S.; PEROTTO, S.; TURNAU, K.; BAREA, J. M. The contribution of arbuscular mycorrhizal fungi in sustainable maintenance of plant health and soil fertility. Biology and Fertility of Soils, v.37, n.1, p.1-16, 2003.

JOHNSON, N. C.; GRAHAM, J. H.; SMITH, F. A. Functioning of mycorrhizal associations along the mutualism parasitism continuum. New Phytologist, v.135, n.4, p.575, 1997.

JORDAN, N.R.; ZHANG J.; HUERD S. Arbuscular-mycorrhizal fungi: potential roles in weed management. Weed Research, v.40, n.5, p.397-410, 2000. 
KJOLLER, R.; ROSENDAHL, S. Effects of fungicides on arbuscular mycorrhizal fungi: differential responses in alkaline phosphatase activity of external and internal hyphae. Biology Fertility Soils, v.31, p.361-365, 2000.

KLING, M.; JAKOBSEN, I. Direct application of carbendazim and propiconazole at field rates to the external mycelium of three arbuscular mycorrhizal fungi species: effect on ${ }^{32} \mathrm{P}$ transport and succinate dehydrogenase activity. Mycorrhiza, v.7, n.1, p.33-37, 1997.

KOIDE, R. T.; DICKIE, I. A. Effects of mycorrhizal fungi on plant populations. Plant and Soil, v.244, p.307-317, 2002.

KÖPKE, U. Methods for studying root growth. In: RUSSEL, R. S.; IGUE, K.; MEHTA, Y. R. J. (Ed.). The soil/root system in relation to Brazilian agriculture. Londrina: IAPAR, 1981. p.303-318.

KORIN. Nutri Bokashi: fertilizante orgânico composto (folder). Ipeúna: Korin Agropecuária, 2004. 2p.

KURLE, J. E.; PFLEGER, F. L. The effects of cultural practices and pesticides on VMA fungi. In: PFLEGER, J. E.; LINDERMAN, R.G. (Ed.) Mycorrhizal and plant health. St. Paul: The Americam Phytopathological Society, 1994. cap.5, p.101-131.

LIMA, C. L. R.; SILVA, A . P.; IMHOFF, S.; LIMA, H. V.; LEÃO, T. P. Heterogeneidade da compactação de um latossolo vermelho-amarelo sob pomar de laranja. Revista Brasileira de Ciência do solo, v.28, n.3, p. 409-414, 2004.

LORENZI, H. Plantas daninhas do Brasil: terestres, aquáticas, parasitas e tóxicas. 3.ed. Nova Odessa: Instituto Plantarum, 2000. 607p. 
MARTINS, C. R.; CANTILLANO, R. F. F.; TREPTOW, R.; FARIAS R. M.; ROMBALDI, C. V. Influência do manejo do solo na conservação, qualidade sensorial, teor de nutrientes e incidência de fitopatias e fisiopatias pós-colheita de pêssegos cv. Cerrito. Revista Brasileira Fruticultura, v. 24, n. 2, p.359-363, 2002.

MARSCHNER, H. Mineral nutrition of higher plants. 2.ed. San Diego: Academic Press, 1995. 889p.

MATHEIS, H. A. san M.; VICTORIA FILHO, R.. Efeitos de diferentes coberturas mortas obtidas a partir do manejo mecânico com roçadeira latreral na dinâmica populacional de pantas daninhas em citros. Piracicaba, 2004. 68p. Dissertação (Mestrado) - Escola Superior de Agricultura “Luiz de Queiroz”, Universidade de São Paulo.

MATTOS JUNIOR, D.; QUAGGIO, J. A.; CANTARELLA, H.; CARVALHO, S. A. Superfície de resposta do tangor 'Murcott' à fertilização com N, P e K. Revista Brasileira de Fruticultura, v.26, n.1, p.164-167, 2004.

MAZZA, J. A.; VITTI, G. C.; SILVA, M. M. Características de solo e desenvolvimento radicular de citros (compact disc). In: SIMPÓSIO SOBRE FISIOLOGIA, NUTRIÇÃO, ADUBAÇÃO E MANEJO PARA PRODUÇÃO SUSTENTÁVEL DE CITROS, Piracicaba, SP, 2000. Anais. Piracicaba: POTAFOS, 2000.

MCGONIGLE, T.P.; MILLER, M.H.; EVANS, D.G.; FAIRCHILD, G.L.; SWAN, J.A. A new method which gives an objective measure of colonization of roots by vesicular-arbuscular mycorrhizal fungi. New Phytologist, v 115, p495-501, 1990. 
MELLONI, R.; CARDOSO, J. B. N. Quantificação de micélio extrarradicular de fungos micorrízicos arbusculares em plantas cítricas. Piracicaba, 1996. 83p. Dissertação (Mestrado) - Escola Superior de Agronomia “Luiz de Queiroz”, Universidade de São Paulo.

MELLONI, R.; NOGUEIRA, M. A.; FREIRE, V. F.; CARDOSO, E. J. B. N. Fósforo adicionado e fungos micorrízicos arbusculares no crescimento e nutrição mineral de limoeiro-cravo [Citrus limonia (L.) Osbeck]. Revista Brasileira de Ciência do Solo, v.24, p.767-775, 2000.

MILLER, R. L.; JACKSON, L. E. Survey of vesicular-arbuscular mycorrhizae in lettuce production in relation to management and soil factors. The Journal of Agricultural Science, v.130, n.2, p.173-182, 1998.

MOREIRA, C. S. Estudo da distribuição do sistema radicular da laranjeira 'Pêra' (Cistrus sinensis, Osbeck) com diferentes manejos de solo. Piracicaba, 1983. 97p. Tese (Livre-Docência) - Escola Superior de Agricultura "Luiz de Queiroz", Universidade de São Paulo.

MOREIRA, C. S. O sistema radicular das plantas cítricas. In: SEMINÁRIO INTERNACIONAL DE CITROS, 2, Campinas, SP, 1992. Anais. Campinas: Fundação Cargill, 1992. p.67-89.

NEVES, C. S. V. J.; DECHEN, A. R.; FELLER, C.; GONZALEZ, M.G.N. Influência de sistemas de manejo de solo em pomar de tangerina -'Poncã' sobre limão-'cravo' em Latossolo roxo. Revista Brasileira de Fruticultura, v. 20, n.3, p. 367-374, 1998. 
NEVES, C. S. V. J.; DECHEN, A. R.; MEDINA, C. C.; GUIMARÃES, M. F. Comparison of citrus rooting evaluation methods using root images in soil profiles and root weight. Revista Pequisa Agropecuária Brasileira, v.35, n.12, p.25372541, 2000.

NÓBREGA, J. C. A.; LIMA, J. M.; CURI, N.; SIQUEIRA, J. O.; MOTTA, P. E. F. Fosfato e micorriza na estabilidade de agregados em amostras de latossolos cultivados e não-cultivados. Pesquisa Agropecuária Brasileira, v.36, n.11, p.14251435, 2001.

OADES, J. M. Soil organic matter and structural stability: mechanisms and implications for management. Plant and Soil, v.76, p.319-337, 1984.

OLIVEIRA, A. A. R.; SANDERS, F. E. Effect of management practices on mycorrhizal infection, growth and dry matter partitioning in field-grown bean. Pesquisa Agropecuária Brasileira, v.34, n.7, p.1247-1254, 1999.

OLIVEIRA, L. F. C.; VIEIRA, D. B.; SOUZA, I. S. Estudo do sistema radicular da tangerineira 'Cleópatra' com copa de laranjeira 'Pêra'. Laranja, v.19, n.1, p107116. 1998.

PANCHABAN, S. Effect of EM on growth and field of corn. In: INTERNATIONAL CONFERENCE ON KYUSEI NATURE FARMING, 1., Khon Kaen, 1989. Proceedings. Washington: Agricultural Research Service/USDA, 1991. p.132-139.

PAUL, E. A.; CLARCK, F. E. Soil microbiology and biochemistry. United Kingdon: Academic Press, 1989. 275p. 
PENG, S.; EISSENSTAT, D. M.; CRAHAM, J. H.; WILLIAMS, K.; HODGE N. C. Growth depression in mycorrhizal citrus at high-phosphorus supply Plant Physiology, v.101, p.1063-1071, 1993.

PIMENTEL GOMES, F. Curso de estatística experimental. 11.ed. São Paulo: Nobel, 1985. 466p.

PHILLIPS, J. M.; HAYMAN, D. S. Improved procedures for clearing roots and staining parasitic and vesicular-arbuscular mycorrhizal fungi for rapid assessment of infection. Transactions of the British Mycological Society, v. 55, p.158-161, 1970.

\section{PLANETA ORGÂNICO Citricultura Orgânica I.}

www.planetaorganico.com.br/citricult1.htm. (30 jan. 2005).

QUAGGIO, J. A.; VAN RAIJ, B.; PIZA JUNIOR. Recomendações para frutíferas. In:VAN RAIJ, B.;CANTARELLA H.; QUAGGIO, J.A.;FURLANI, A.M.C. Boletim Técnico n. 100: Recomendações de adubações e calagem para o Estado de São Paulo , 2.ed. Campinas: Instituto Agronômico/Fundação IAC, 1997. 285p.

QUAGGIO, J. A.; MATTOS JUNIOR, D.; CANTARELLA, H.; TANK JUNIOR, A. Fertilização com boro e zinco no solo em complementação à aplicação via foliar em laranjeira 'Pêra’. Pesquisa Agropecuária Brasileira, v.38, n.5, p.627-634, 2003.

RIZZO, L. T. B.; CASTRO S. S Indicadores da resiliência do latossolo vermelho escuro cultivado com citros e eucalipto em Itapetininga - SP: recuperação de um solo degradado pela compactação. São Paulo, 2000. 200p. Tese (Doutorado) - Faculdade de Filosofia, Letras e Ciências Humanas, Universidade de São Paulo. 
RODRIGUEZ et al. Citricultura brasileira. 2.ed. Campinas: Fundação Cargill, 1991. v.1, 230p.

SAKAKIBARA, C. O fundamento da agricultura natural. São Paulo: Fundação Mokiti Okada, 1998. 46p.

SANCHES, A.C. Manejo para produção sustentável de citros: Resultados práticos (compact disc). In: SIMPÓSIO SOBRE FISIOLOGIA, NUTRIÇÃO, ADUBAÇÃO E MANEJO PARA PRODUÇÃO SUSTENTÁVEL DE CITROS, Piracicaba, SP, 2000. Anais. Piracicaba: POTAFOS, 2000.

SANDERS, I. R.; KOIDE, R. T.; SHUMWAY, D. L. Community-level interaction between plants and vesicular-arbuscular mycorrhizal fungi. In: VARMA, A.; HOCK, B. (Ed.) Mycorrhiza: structure, function, molecular biology and biotechnology. New York: Springer-Verlag, 1995, p.608-621.

SARTORI, V. C.; AZEVEDO, J. L. Dinâmica das populações de fungos endofíticos e epifíticos, impacto ecológico em diferentes sistemas de produção da macieira (Malus domestica) e seu potencial biotecnológico. Curitiba, 2003. 109p. Tese (Doutorado) - Universidade Federal do Paraná.

SCHREINER, R. P.; BETHLENFALVAY, G. J. Mycorrhizae, biocides, and biocontrol. 4. Response of a mixed culture of arbuscular mycorrhizal fungi and host plant to three fungicides. Mycorrhiza, v.23, n.2, p.189-195, 1996.

SHORROCKS, V. M. The occurrence and correction of boron deficiency. Plant and Soil, v.193, p.121-148, 1997. 
SILVA, I. F.; MIELNICZUCK, J. Ação do sistema radicular de plantas na formação e estabilização de agregados de solo. Revista Brasileira de Ciência do Solo, v.21, p.113-117, 1997a.

SILVA, I. F.; MIELNICZUCK, J. Avaliação do estado de agregação do solo afetado pelo uso agrícola. Revista Brasileira de Ciência do Solo, v.21, p313-319, 1997b.

SILVEIRA, A. P. D. Micorrizas. In: CARDOSO, E. J. B. N.; TSAI, S. M.; NEVES, M. C. P. (Ed.). Microbiologia do Solo. Campinas: Sociedade Brasileira de Ciência do Solo, 1992. cap.19, p.257-282.

SILVEIRA, A.P.D. da. Avaliação de fungos micorrízicos arbusculares e sua importância ambiental. In: FRIGHETTO, R. T. S. ; VALARINI, P.J. Manual técnico: Indicadores biológicos e bioquímicos da qualidade do solo. Jagariúna: Embrapa, 2000. p.61-77.

SMITH, S. E.; READ, D. J. Mycorrhizal Symbiosys. 2.ed. San Diego: Academic Press, 1996. 605p.

STOLF, R. A compactação do solo e perspectivas da subsolagem em citros. Laranja, n.2 p283-308, 1987.

STOLF, R.; FERNANDES, J.; FURLANI NETO, V. L. Recomendação para uso do penetrômetro de impacto: Modelo IAA/Planalsucar-Stolf. Piracicaba: PLANALSUCAR, 1983. 10p.

STOLF, R. Teoria e teste experimental de fórmulas de transformação de dados de penetrômetro de impacto em resistência do solo. Revista Brasileira de Ciência do Solo, v.15, p.229-235, 1991. 
SUKARNO, N.; SMITH, S.E.; SCOTT, E. S. The effect of fungicides on vesiculararbuscular mycorrhizal fungi and plant growth. New Phytologist, v.25, p.39-147, 1993.

SUKARNO, N.; SMITH, F. A.; SMITH, S. E.; SCOTT, E. S. The effect of fungicides on vesicular-arbuscular mycorrhizal symbiosis. II. The effects on area of interface and efficiency of P uptake and transfer to plant. New Phytologist, v.132, n.4, p.583592, 1996.

SUKARNO, N.; SMITH, F. A.; SCOTT, E. S.; JONES, G. P.; SMITH S. E. The effect of fungicides on vesicular-arbuscular mycorrhizal symbiosis. III. The influence of VA mycorrhiza on phytotoxic effects following application of fosetyl-Al and phosphonate. New Phytologist, v.139, p.321-330, 1998.

TERSI, F. E. A.; ROSA, S. M. A subsolagem no manejo de solo para os pomares de citros. Laranja, v.16, n.2, p.289-298. 1995.

TERSI, F. E. A.; SOUZA, E. C. A.; RIGOLIN, A. T.. Efeitos de métodos de manejo de plantas daninhas em crescimento, produtividade, qualidade do suco e estado nutricional de um pomar cítrico. Laranja, v.20, n.1, p.119-133, 1999.

THOMAZINI, M. J. Recomendações gerais para o controle das principais pragas dos citros no Estado do Acre. Rio Branco: EMBRAPA ACRE, nov. 2001. 4p. (Instruções Técnicas n.37)

TISDALL, J. M. Possible role of soil microrganisms in aggregation in soils. Plant and Soil, v.159, p.115-121, 1994. 
TRAPPE, J. M.; MOLINA, R.; CASTELLANO, M. Reactions of mycorrhizal fungi and mycorrhiza formation to pesticides. Annual Review of Phytopathology, v.22, p.331-359, 1984.

VALLADARES, G. S.; PEREIRA, M. G.; SOUZA, J. M. P. F.; PÉREZ, D. V.; ANJOS, L. H. C. Notas científicas: Disponibilidade de boro e correlação com propriedades dos solos do Estado do Rio de Janeiro. Pesquisa Agropecuária Brasileira, v.34, n.3, p.493-498, 1999.

VALARINI, P. J.; DIAZ ALVAREZ, M. C.; GASCÓ, J. M.; GUERREIRO, F.; TOKESHI, H. Assesment of soil property by organic matter and EM-Microrganism incorporation. Revista Brasileira de Ciência do Solo, v.27, n.3, p.519-525, 2003.

VALDEBENITO-SANHUEZA, R. M. Leveduras para o biocontrole de fitopatógenos. In: MELO, I. S.; AZEVEDO, J. L. Controle Biológico. Jaguariúna: Embrapa Meio Ambiente, 2000. 388p.

YAMADA, T.; CABRERA, R.A.D.; LEÃO, H.C.; NOGUEIRA, C. Manejo da matéria orgânica e da adubação boratada para produção sustentável de citros: hipóteses de trabalho e resultados preliminares (compact disc). In: SIMPÓSIO SOBRE FISIOLOGIA, NUTRIÇÃO, ADUBAÇÃO E MANEJO PARA PRODUÇÃO SUSTENTÁVEL DE CITROS, Piracicaba, SP, 2000. Anais. Piracicaba: POTAFOS, 2000.

YERMIYAHU, U.; KEREN, R.; CHEN, Y. Effect of composted organic matter on boron uptake by plants. Soil Science Society of America Journal, v.65, p.14361441, 2001. 
ZHAO, Q. Effect of EM on peanut production and soil fertility in red soil region of China. In: INTERNATIONAL CONFERENCE ON KYUSEI NATURE FARMING, 4, Paris, 1995. Proceedings. Washington: Agricultural Research Service/USDA, p.99-102. 1998. 